\title{
MYSTIK BLIR VETENSKAP
}

Donnerska institutet

för religionshistorisk och kulturhistorisk forskning 1956-2021 



\title{
MYSTIK BLIR VETENSKAP \\ Donnerska institutet
}

för religionshistorisk och kulturhistorisk forskning 1956-2021

\author{
NILS G. HOLM
}

Scripta Instituti Donneriani Aboensis 30

Turku/Åbo 2021 
Mystik blir vetenskap: Donnerska institutet för religionshistorisk och kulturhistorisk forskning 1956-2021 Scripta Instituti Donneriani Aboensis, 30 (2021)

(c) Attribution 4.0 International (CC BY 4.0)

https://doi.org/10.30674/scripta.102185

Pärmbild

Uno Donner: Dödsskallar bakom ridån, 1916. Stiftelsens för Åbo Akademi bildsamlingar.

Layout

Maria Vasenkari

ISSN 0582-3226

ISBN 978-952-12-4045-4 (print), 978-952-12-4046-1 (online)

Painosalama Oy

Turku 2021 


\section{Innehållsförteckning}

FÖRORD 7

INLEDNING 9

Donatorerna Uno och Olly Donner

FÖRbEREDELSER FÖR OCH MOTTAGANDET AV DONATIONEN I5

Det fortsatta arbetet Med Donationen I9

FRÅN INTERIMSSTYRELSE TILL ORDINARIE STYRELSE 24

$\begin{array}{ll}\text { TIDEN MED PROFESSUR } & 28\end{array}$

Ringgrens tid $\quad 28$

Hartmans tid 3I

Biezais tid 35

Ahlbäcks FÖRESTÅNDARSKAP 43

Fler stipendier $\quad 43$

Konferenser och kollokvier $\quad 44$

Professuren lösgörs från institutet $\quad 45$

H.W. Donners frånfälle $\quad 47$

Nya stadgar och nytt reglemente $\quad 48$

Fortsatt konferensverksamhet $\quad 49$

Utställningar och stipendier $\quad 50$

Ekonomisk depression $\quad 50$

Ämnet religionshistoria flyttar 50

Donnerska flyttar till Humanisticum 5 I 
ILLMANS FÖRESTÅNDARSKAP $\quad 52$

Anställda och bibliotekets utveckling $\quad 52$

Stipendier och pris $\quad 56$

Symposier, rundabordskonferenser, Aboagora $\quad 57$

Strategi för Donnerska institutet 2020-2022 62

Förändringar i det religiösa klimatet $\quad 64$

Den aktuella styrelsen $\quad 66$

Mot framtiden $\quad 66$

KÄLLOR OCH LitTERATUR 70

Otryckta källor $\quad 70$

Intervjuer vårvintern $2020 \quad 7 \mathrm{I}$

Tryckta källor och litteratur $\quad 7$ I

$\begin{array}{ll}\text { Personkegister } & 73\end{array}$

BILAGOR

I. Förteckning över konferenserna $\quad 77$

2. Styrelsen genom åren $\quad 79$

3. Donnerska institutets pristagare $\quad 84$

4. Stipendiater vid Donnerska institutet 2013-2020 87 


\section{Förord}

Min kontakt med Donnerska institutet går tillbaka till år 1962 då jag som nybliven student började studera teologi vid Åbo Akademi. Till studierna hörde då att åhöra den nyligen tillträdde professorn i religionshistoria Helmer Ringgrens föreläsningar om världens religioner. Det var en fascinerande kurs. Också hans efterföljande kurser om bl.a. mysteriereligionerna under hellenistisk tid var givande. Allt detta gjorde att jag så småningom valde ämnet religionshistoria som huvudämne i mina studier vid humanistiska fakulteten. År I 973 erhöll jag licentiatexamen vid Åbo Akademi men kom att avlägga doktorsexamen vid Uppsala universitet av förekommen anledning. När jag sedan från 1979 började fungera som professor i religionshistoria (senare religionsvetenskap) trädde jag in i styrelsen för Donnerska institutet och kvarstod där i över 30 år.

I början av det exceptionella året 2020 med pandemi fick jag i uppdrag av styrelsen för Donnerska institutet att skriva institutets historik.

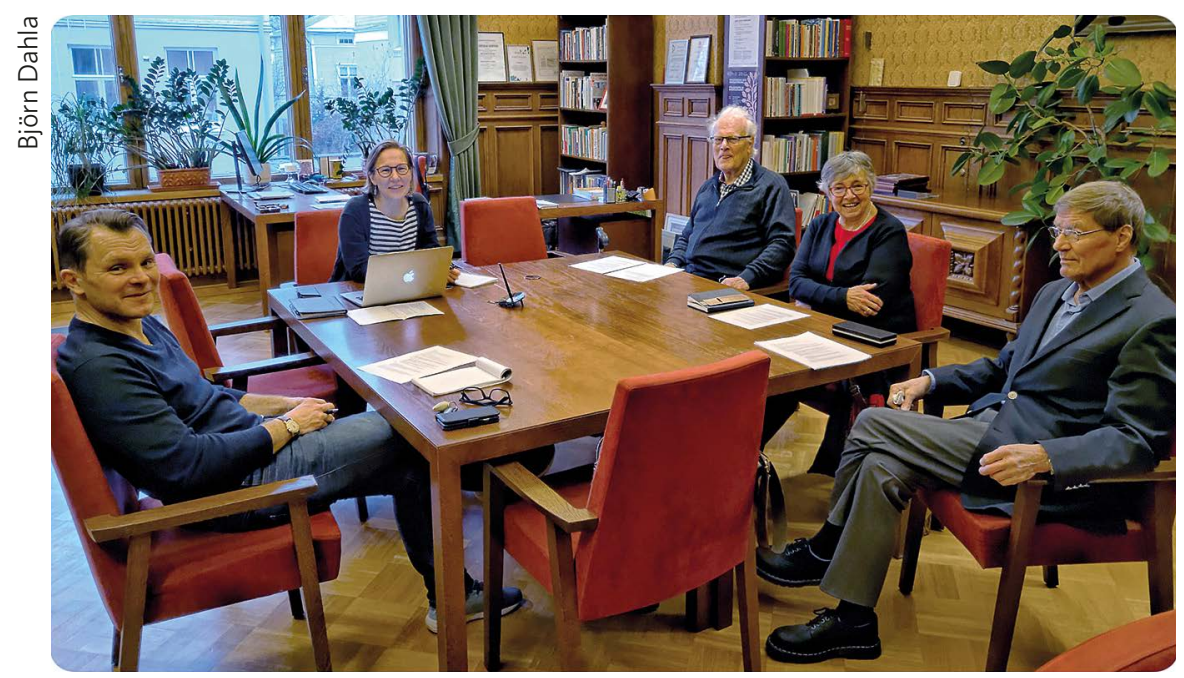

Arbetsgruppen som arbetar med historiken samlades i Humanisticum den 14.1.2020, från vänster: Joakim Alander, Ruth IIIman, Nils G. Holm, Ulrika Wolf-Knuts och Tore Ahlbäck. 
Precis just innan akademins lokaler stängdes definitivt för en tid på våren 2020 fick jag ut så mycket material (protokoll, årsberättelser etc.) att jag hemma och på stugan i skärgården kunde skriva det mesta av själva texten. För mig har uppgiften varit synnerligen intressant och givande. Att få penetrera historien på djupet efter alla tidigare kontakter med institutet har varit till stor glädje för mig.

Det är många som förtjänar ett ordentligt tack i detta sammanhang. För det första är det Donnerska institutets styrelse som givit mig detta uppdrag som jag vill tacka. Personalen vid institutet har mycket beredvilligt hjälpt mig med att få fram material. Det är jag synnerligen glad och tacksam över. Mitt tack riktar jag också till Handskriftsavdelningen vid Åbo Akademis bibliotek, Centralarkivet vid Åbo Akademi samt till Stiftelsen för Åbo Akademi. Tacket går också till dem som ställde upp för intervju rörande erfarenheterna av institutet. Också språkgranskaren Kati Palmberg och ombrytaren Maria Vasenkari är jag skyldig ett tack. Sist men inte minst tackar jag redaktionsrådet med Ruth Illman, Tage Kurtén, Ulrika Wolf-Knuts, Tore Ahlbäck och Joakim Alander. Det har varit mig en glädje att få samarbeta med er.

Åbo den 24 januari 202 I

Nils G. Holm 


\section{Inledning}

Donnerska institutet har en intressant historia som behöver få en belysning. Det grundades i syfte att utforska mysteriereligionernas och ockultismens inflytande på olika religioners och kulturers uppkomst och utveckling. Ett av huvudändamålen var ett fullständigt utforskande av Rudolf Steiners filosofi och tankevärld. Hos en del har detta uppfattats som en bundenhet till den antroposofiska ideologin, en uppfattning man ännu kan stöta på hos vissa. Idag är dock institutet ett bibliotek och forskningsinstitut som arbetar efter vedertagna vetenskapliga principer och är en betydande aktör inom kultur och vetenskap inte enbart på nordisk nivå utan också på världsvitt plan. Utvecklingen har gått från samlande av böcker och information till forskning och vetenskapligt hantverk. Titeln Mystik blir vetenskap ska just förstås i den meningen. Verksamheten har nu pågått i över 60 år och framtiden ser lovande ut. Här tecknas några av de viktigaste elementen i denna utveckling.

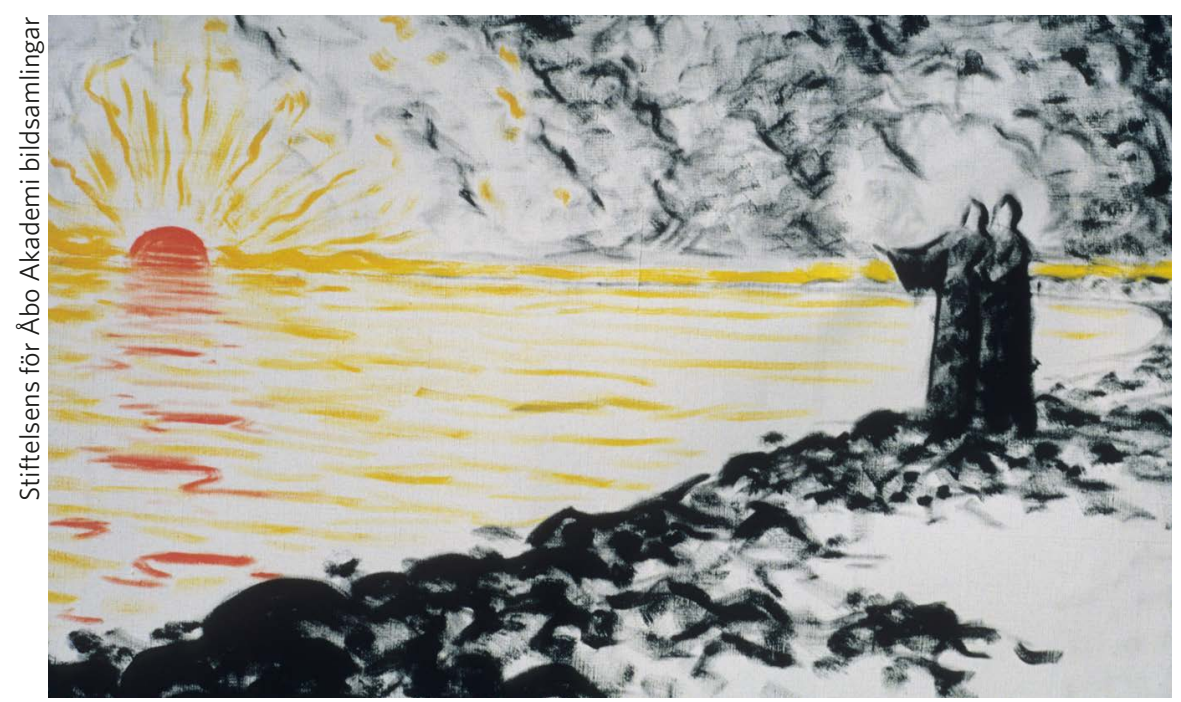

Solnedgång, tavla målad av Uno Donner år 1916. 


\section{Donatorerna Uno och Olly Donner}

Uno Donner föddes den 5 dec. I 872 i Helsingfors och dog i Arlesheim, Schweiz, den 23 juni I 958 . Hans hustru Olly (Olga) föddes den 28 sept. I 88 I och dog också i Arlesheim, men två år tidigare, alltså den 22 sept. I956. Olly var född Sinebrychoff i Helsingfors. Hon var enda barnet till Anna Nordenstam (I 854-I 944) och Nicolas Sinebrychoff (I $856-$ I 896). Anna Nordenstam hade varit kejsarens hovdam i S:t Petersburg;

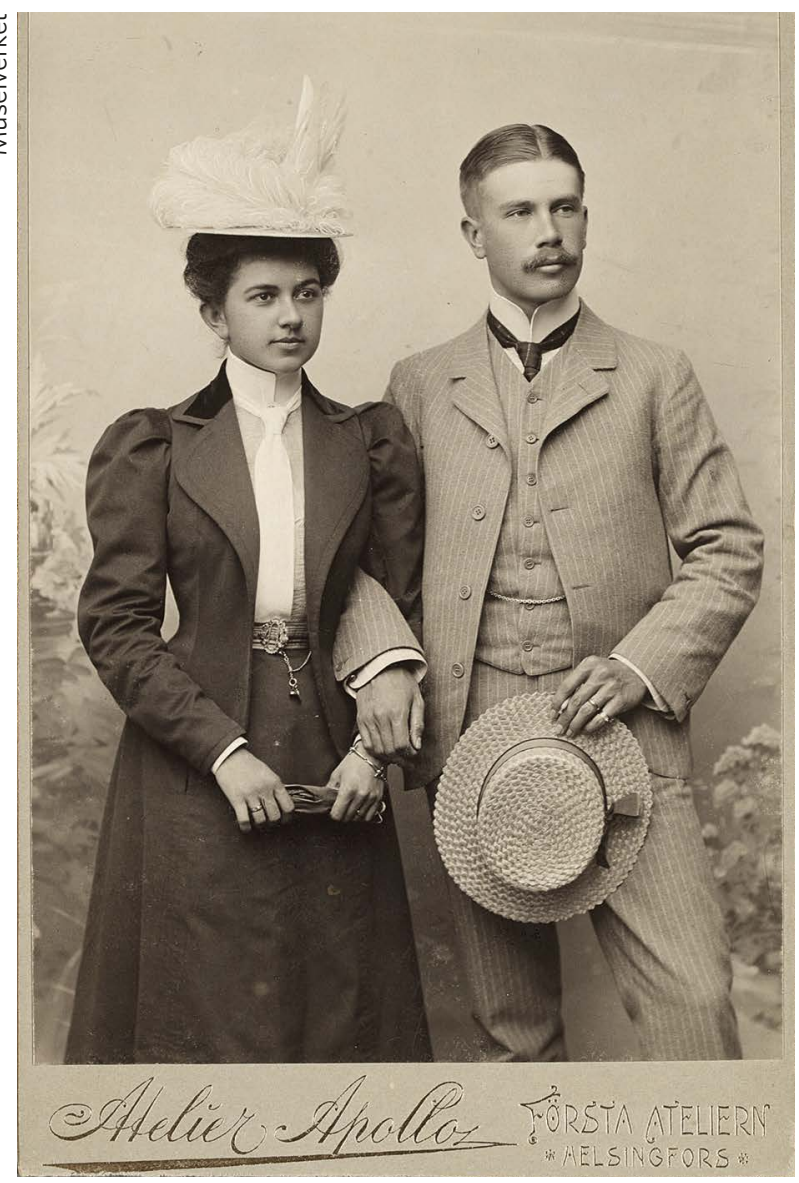

Nicolas Sinebrychoff var ägare av det framgångsrika bryggeriet Sinebrychoff.

Olly Donner växte upp i en mycket privilegierad miljö. Hon fick en omfattande utbildning, studerade flera år vid olika internatskolor i Europa. Utöver sitt modersmål svenska lärde hon sig franska, ryska, tyska och engelska. Under sina studier i Dresden lärde hon känna Uno Donner, som var ingenjör. De gifte sig år I 900 i Schweiz på en ort nära Lausanne.

Olly och Uno Donner, Atelier Apollo, 1900. 
Uno Donner kom från en familj med akademisk bakgrund. Hans far Otto Donner var professor i sanskrit och jämförande språkvetenskap. Modern Louise var född Malm och dotter till en köpman i Österbotten. Det var meningen att Uno skulle gå den akademiska banan men bl.a. på grund av "dålig hälsa" blev han ingenjör och affärsman i stället. Han dimitterades från tekniska högskolan som diplomingenjör I 896, och utbildningen kompletterades genom studier i England och Tyskland. Han blev framgångsrik inom spinneriverksamheten. Han grundade landets första kamgarnsspinneri i Gammelstaden och var senare aktiv och intresserad medlem och även ordförande för olika spinnerier i Finland. I ledningen för Sinebrychoffs fabriker var han även verksam under många år.

Paret Uno och Olly Donner levde ett kringresande liv i början av äktenskapet men hade alltid en fast punkt i en bostad i Helsingfors. Bland annat besökte de Egypten i början av I900-talet. Åren I 9 I 4 till r 92 I bodde de i Sverige. Från I 928 till I 946 ägde de herrgården Gerknäs i Lojo, och de ägde även parceller på andra håll i södra Finland.

Väsentligt för paret Donner var att de år I9 3 i London stiftade bekantskap med antroposofin och Rudolf Steiner. De gjorde många resor till Dornach i Schweiz där antroposofins centrum Goetheanum

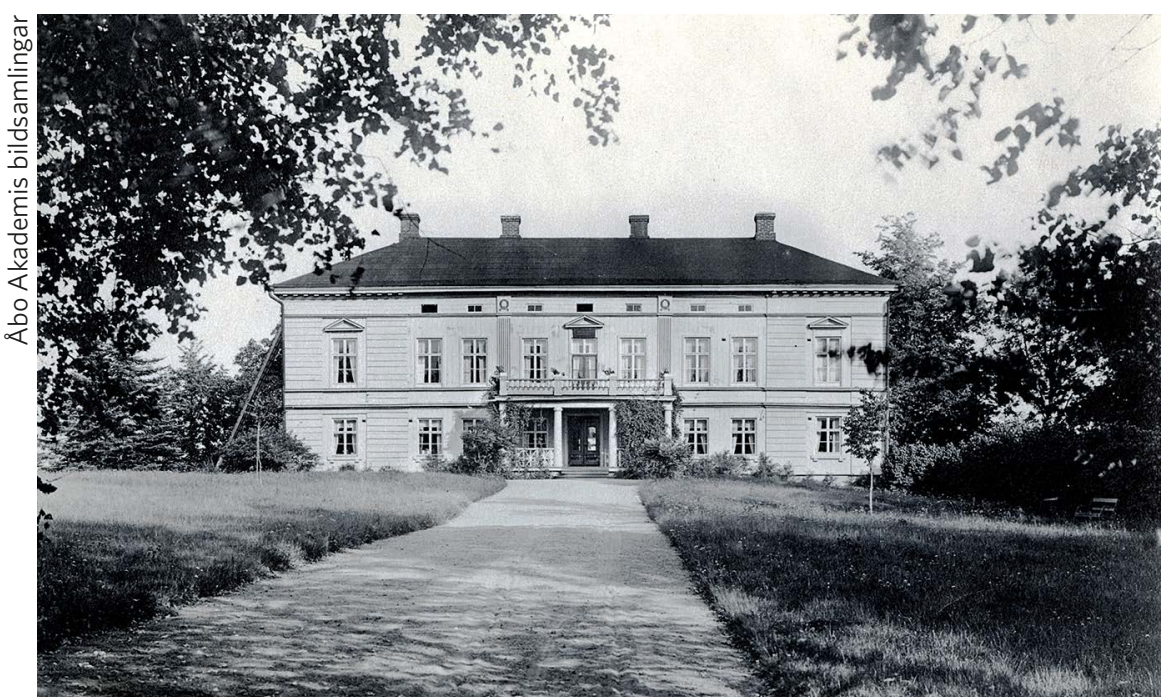

Gerknäs gård i Lojo, Finland. Ägd av makarna Donner 1928-1946. 


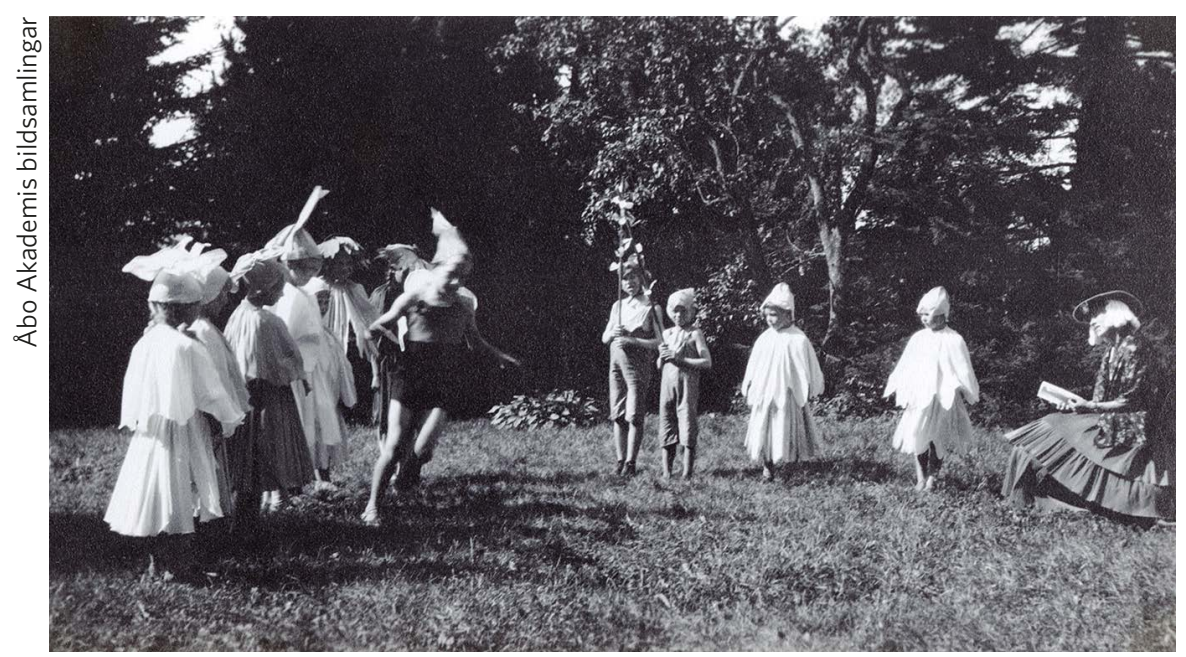

Uppe: Barn uppträder med en scen ur Olly Donners populära skådespel som en del av sagoteatern som hölls vid Gerknäs gård på 1940-talet. Nere till vänster: Olly Donner på en av sina resor till Schweiz, ca 1900. Nere till höger: Uno Donner med pipa på trappan till Beatebergs herrgård i Uppland, Sverige.
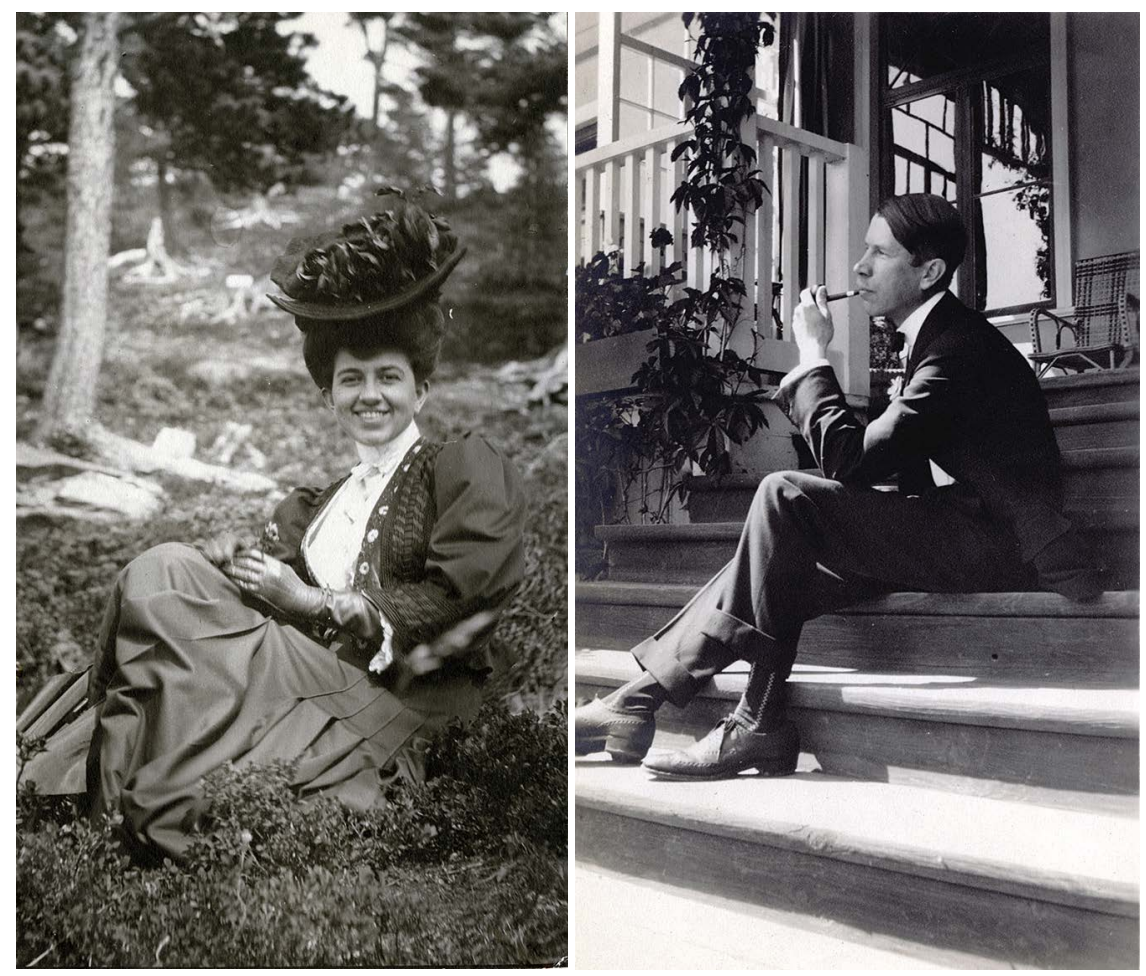
ligger. År 1923 grundade Uno Donner Antroposofiska sällskapet i Finland. Han var dess ordförande åren 1923-I932. På många sätt stödde han sällskapet i Finland och höll också själv föreläsningar. Emellertid fick han inte I93I fortsatt förtroende som ordförande och tog illa vid sig, och han avhöll sig efter det konsekvent från att stöda sällskapet i Finland. Uno försökte sig under Gerknästiden på biodynamisk odling enligt antroposofiska metoder. Han var den förste i Finland att pröva på den odlingsmetoden.

Under Gerknästiden koncentrerade sig Olly Donner på Waldorfpedagogik. Hon var

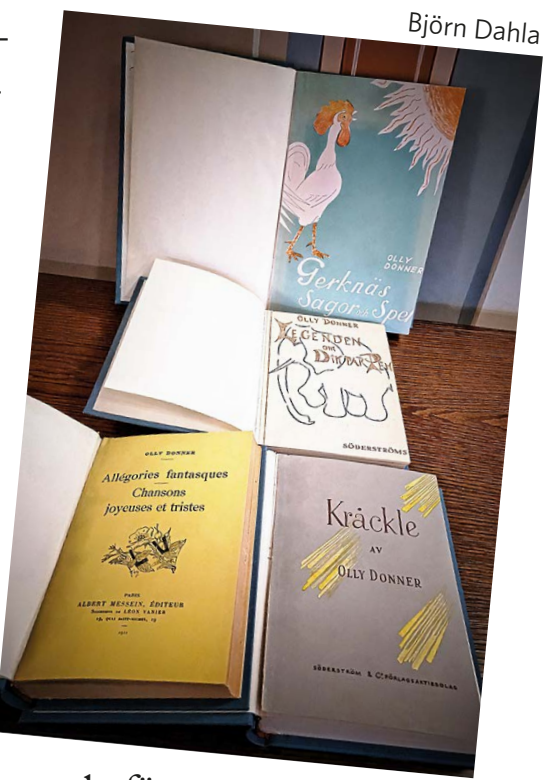
en generös understödjare av Gustafsbergs vårdanstalt för barn med utvecklingsstörning i Gerknäs. Vidare stödde hon Gerknäs skola och Gerknäs sommarkoloni. Olly skrev många pjäser med musik för barnen i Gerknäs skola och för sommarkolonin. På många sätt var hon en nyskapare inom barnpedagogiken.

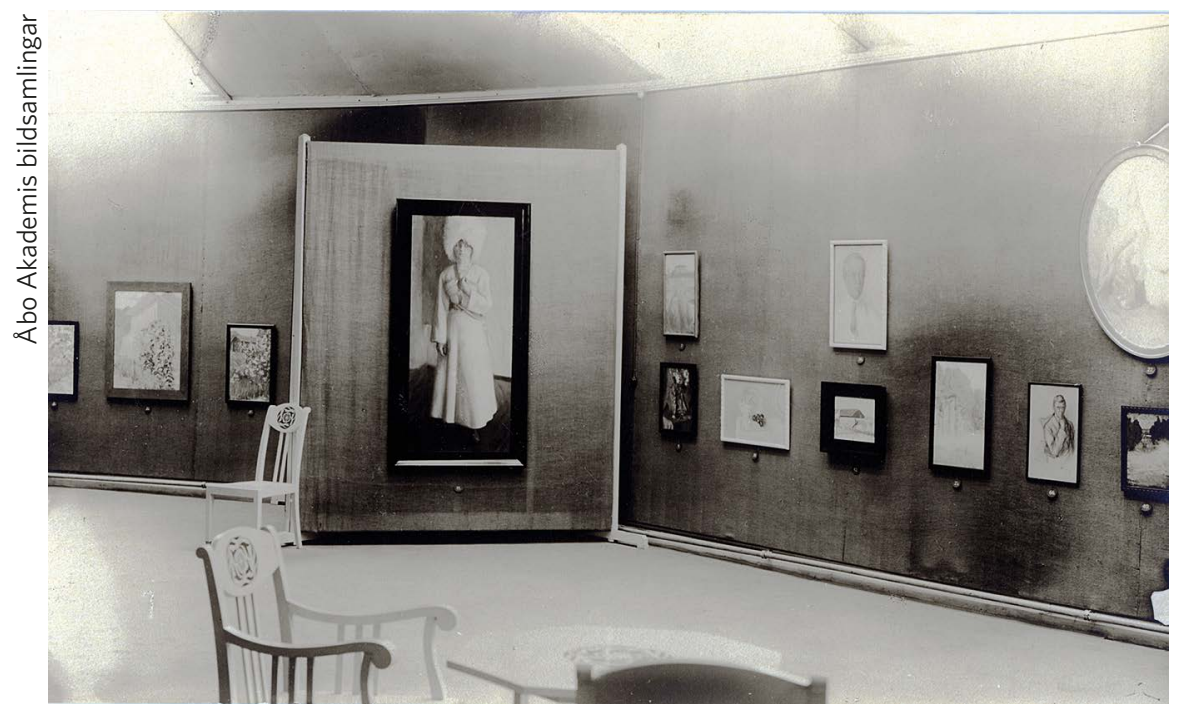

Uno Donners utställning i galleri Strindberg i Helsingfors, oktober 1915. I mitten Olly Donner i helfigur, tavlan finns i Donnerska institutet i Åbo. Ovan: Böcker av Olly Donner. 


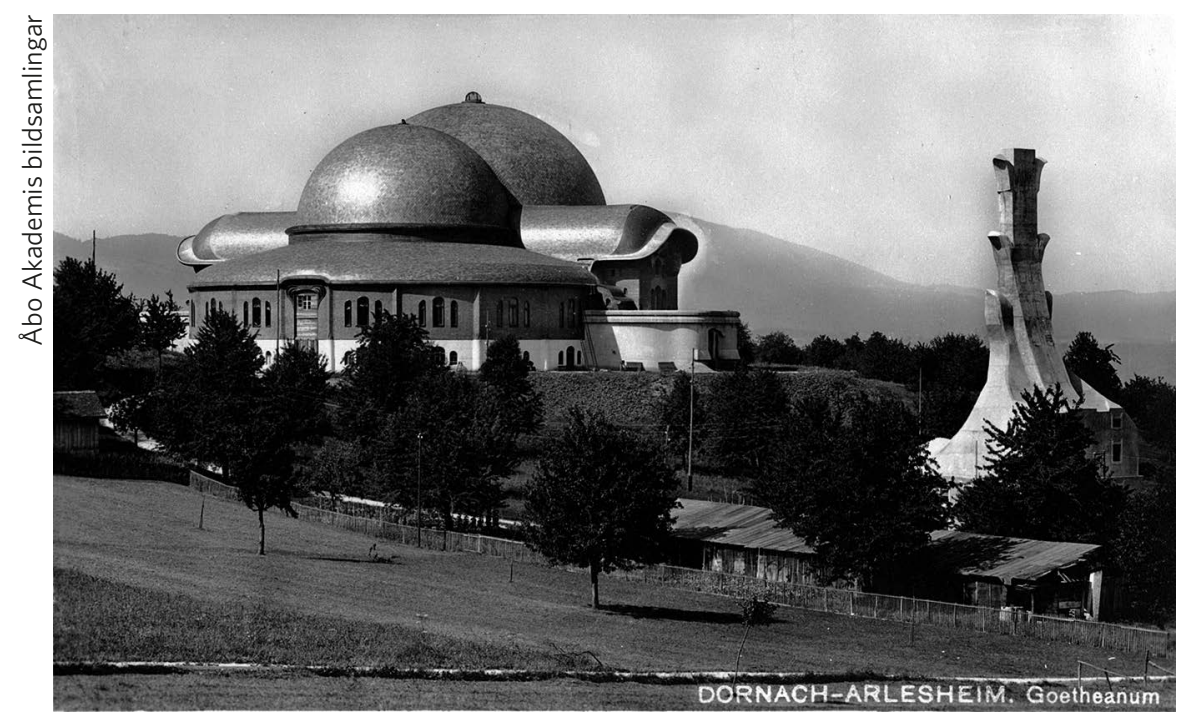

Det första Goetheanum i Dornach, Schweiz. Byggandet inleddes år 1913 men byggnaden totalförstördes i en anlagd brand på nyårsnatten 1922/3. Idag finns ett nybyggt Goetheanum på samma plats.

Konsten var något som ivrigt odlades av paret Donner, mycket i antroposofisk anda. Olly skrev böcker, pjäser och dikter. Hon publicerade sammanlagt 32 böcker. Uno å sin sida odlade måleriet. Han blev en god amatörmålare. En stor och fin målning gjorde han av sin hustru Olly i vinterdräkt med vit huvudbonad i skinn. Den finns att beskåda i Donnerska institutet i dag.

Både Olly och Uno är begravda i minnesparken nära Goetheanum i Dornach.

Det är kanske på sin plats att här nämna att den under senare tid kände Jörn Donners (1933-2020) far var halvbror till Uno Donner. 


\section{Förberedelser för och mottagandet av donationen}

Paret Donner förfogade över en stor förmögenhet. De var barnlösa, och under de sista åren i Arlesheim började de tänka på att donera pengarna till något som skulle stöda den antroposofiska verksamheten. Trots att Ollys kusin Markus Kjöllerfeldt ville att hon skulle behålla egendomen inom Sinebrychoffska släkten blev det ändå så att en donation kunde förverkligas till Stiftelsen för Åbo Akademi i mars 1956.

Ett par år innan donationen ägde rum förde H. W. Donner, brorson till donatorn, en relativt livlig korrespondens med "tant Dolly" och "farbror Uno", som det oftast står i breven. H. W. Donner skriver för det mesta från bostaden i Uppsala eller i Oxford. Någon gång besöker han också donatorerna i Arlesheim. I breven får vi veta lite om deras hälsotillstånd. De var ofta sjuka och tillönskades bättring.

H.W. Donner var förste innehavare av professuren i engelska språket och litteraturen vid Åbo Akademi åren r 932-r 95 I, en professur som

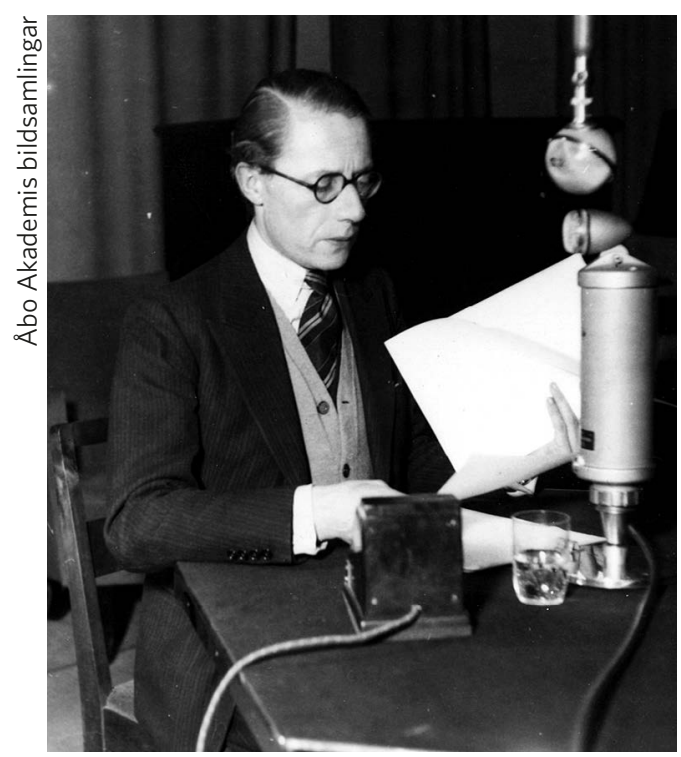
hans far donerat och därför kallas J. O. E. Donners professur i engelska språket och litteraturen. Efter tiden i Åbo flyttade H. W. Donner över till Uppsala universitet som professor i samma ämne. I breven till Uno diskuteras allt möjligt. Det är

Heinrich Wolfgang Donner (1904-1980), 3 dec. 1940. 


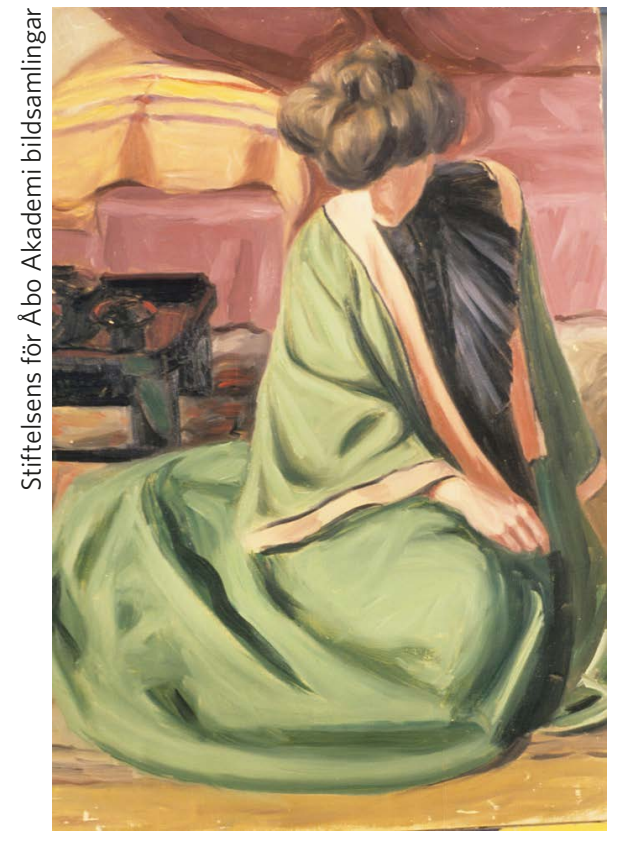

Dam i grön morgonrock, tavla målad av Uno Donner år 1910.

ofta fråga om avyttring av egendom, aktiers värdering, försäljning på Bukowskis, överföring av penningsummor mellan länderna samt frågan om finländskt medborgarskap. Donatorerna hade bott flera år i Sverige.

Det var inte alls klart från början att donationen skulle ske till Stiftelsen för Åbo Akademi. Man diskuterade även en donation till Svenska kulturfonden. H. W. Donners inflytande blev dock avgörande och han ledde diskussionerna så att Stiftelsen för Åbo Akademi blev det mest aktuella alternativet. Rätt tidigt blev därför skattmästaren vid Stiftelsen kontaktad. Vid den här tiden var det Tor-Erik Lassenius som innehade den posten. Vid ett flertal tillfällen diskuterade han donationens förverkligande med olika personer, bl.a. med Finlands Bank. Att minnas är att åren vid mitten av I950-talet var rätt turbulenta i Finland. Bland annat var det generalstrejk I 956 och Urho Kekkonen valdes till president, ett val inte helt utan dramatik. Överföring av stora summor pengar var inte enkelt denna tid.

H. W. Donner var aktiv med att få fram formuleringar för donationsbrevet. Olika förslag skickades över till paret i Arlesheim. I brev av den 3 mars 1956 redogör H. W. Donner mer noggrant för hur donationen borde gå till och framhåller "att donationen måste göras nu, och snabbt. Det räcker inte med en utfästelse om testamente, då ju ett dylikt kan ändras." Donationsbrevet blev följaktligen daterat den 29 mars I 956, ett knappt halvår före Olly Donners frånfälle. Uno Donner levde ett par år längre och fortsatte diskussionerna kring upprättandet av Steinerbiblioteket. 
Donationen upptogs till behandling i Stiftelsens för Åbo Akademi styrelse första gången den 6 april r 956 vid möte i Helsingfors. Man antecknade att man erhållit donationsbrev av "ingeniör Uno Donner och hans maka Olly". Man hade erhållit aktier i Tammerfors Linneoch Jern Manufaktur ab samt i Oy P. Sinebrychoff ab. Medlen skulle tillföras en särskild fond kallad "Fonden för religions- och kulturhistorisk forskning". Man vidlade avskrifter av Donationsbrevet och av Bestämmelser för fonden för Religions- och kulturhistorisk forskning. Det nämns också tydligt att donatorerna befullmäktigat H. W. Donner att"genom ett gåvobrev till stiftelsen överlåta samtliga deras fastigheter i Finland att tillföras Fonden för religionshistorisk och kulturhistorisk forskning." Man framhåller även att $\mathrm{H}$. W. Donner nedlagt ett utomordentligt stort arbete på att få frågan löst. Man beslöt mottaga donationen och tacka donatorerna och H. W. Donner.

H. W. Donner (Heinrich Wolfgang) var född den 12 mars 1904 i Helsingfors. Hans föräldrar var filosofie doktor, docenten vid Kejserliga Alexanders-Universitetet Joachim Otto Evert Donner och Emilia Maria Matilda Ekman. Familjen flyttade till Sverige ett par år före första världskrigets utbrott. H. W. Donner gick i skola i Stockholm och studerade i Uppsala. Han blev

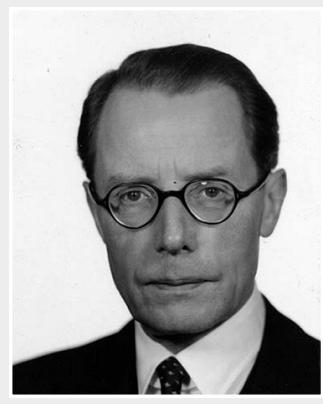
filosofiekandidat 1927, varefter han fortsatte utbildningen i Oxford och disputerade för doktorsexamen 1934. Från 1937 bestred han professuren i engelska språket och litteraturen vid Åbo Akademi. Han avgick därifrån 1951 och blev professor vid Uppsala universitet, fram till att han begärde avsked från den professuren 1966. Från 1959 var han medlem av Stiftelsens för Åbo Akademi delegation och från 1957 av styrelsen för Stiftelsen Academica i Stockholm. Han var dessutom medlem av flera vetenskapliga samfund, och skrev därutöver viktiga arbeten om den engelska poeten Thomas Lovell Beddoes (18031849) och om Shakespeare. En av de viktigaste insatserna gjorde han för Olly och Uno Donners fond i Åbo. Han dog i sitt hem i Oxford nyårshelgen 1981. (Bild: Åbo Akademis bildsamlingar) 

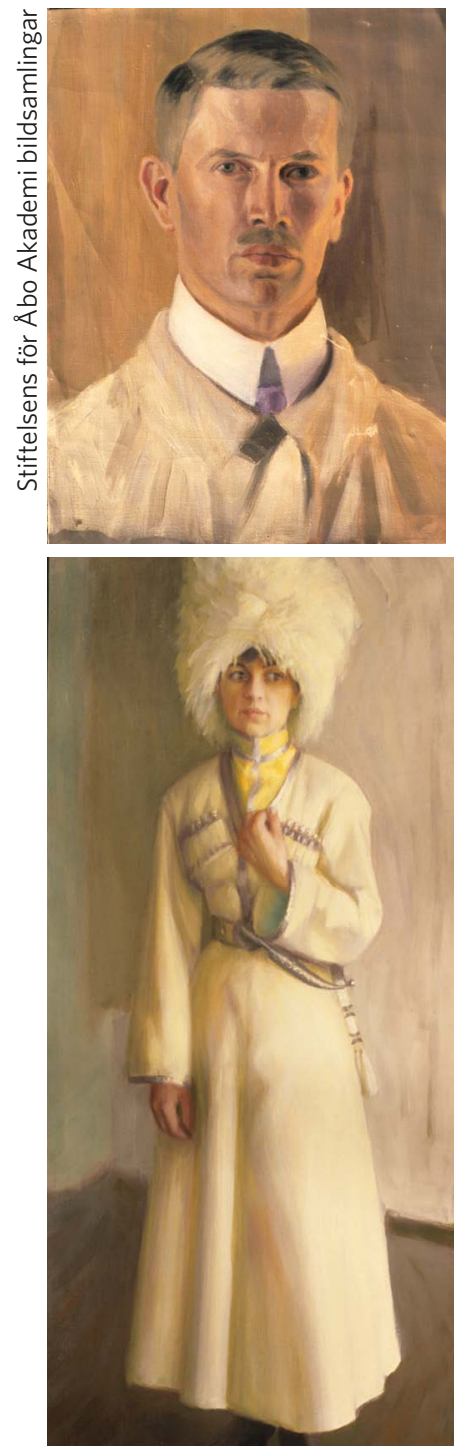

Ovan: Självporträtt, tavla målad av Uno Donner år 1912. Nedan: Konstnärens hustru i maskeraddräkt, tavla målad av Uno Donner år 1912.
H. W. Donner besökte akademin senare våren I 956 och sammanträffade med Åbo Akademis styrelse samt med samtliga medlemmar i Stiftelsens styrelse. I brev av den 7 maj I956 till farbror Uno skriver han: "Samtliga äro mycket tacksamma och positivt inställda. Mest av alla Amos [Anderson], som förklarade att han själv är något av en mystiker och att han tror att ur denna donation kommer det att i Domkyrkans skugga växa fram någonting som kommer att bli av betydelse för hela Norden.”

H. W. Donner fortsätter: "Glädjande var även att Taxell [Lars Erik] efter 24 timmars betänketid åtog sig att i händelse av behov träda i mitt ställe som övervakare av donationens verkställande." Taxell fick så bl.a. en viktig uppgift som bestod $i$ att utarbeta och många gånger revidera stadgarna och tillämpningsbestämmelserna för institutet. Det var viktigt att det juridiskt var så klart som möjligt. Det förefaller ha varit en rätt komplicerad process att få fram de slutliga stadgarna.

Också målningarna som Uno Donner gjort dök upp i breven och H. W. Donner framhåller uttryckligen: "Även med beaktande av all tänkbar anspråkslöshet från Er sida, är det nog ändå kärt för mottagarna av donationen att den enas porträtt målat av den andre donatorn hänger i biblioteket, och detta låter sig säkert väl förena med att Steiners porträtt intar hedersrummet" (brev I 2 maj I956). 


\section{Det fortsatta arbetet med donationen}

Donationsbrevet är som sagt daterat den 29 mars 1956 och underskrivet av både Olly och Uno Donner. Bestämmelserna för donationen är ganska omfattande. Här kan inte alla punkter återges men något $\mathrm{i}$ alla fall. Det som är viktigt är ingressen där det står: "Fondens ändamål är att på strängt vetenskaplig grund befrämja religionshistorisk och kulturhistorisk forskning, främst med beaktande av mysteriereligionernas och ockultismens inflytande på olika religioners och kulturers uppkomst och utveckling." En annan viktig punkt är följande: "Ett av fondens huvudändamål skall vara ett fullständigt utforskande av Rudolf Steiners filosofi och tankevärld." I det kommande "Rudolf Steiner biblioteket" ska ingå samtliga skrifter av honom och dessutom den "vidlyftiga litteratur, vartill han hänvisar".

I samband med omnämnandet av kommande stipendier som ska utges, ingår en passus som förvånat något. Där skrivs följande: "Prästvigda eller vid teologisk fakultet graduerade personer må icke tilldelas stipendier och icke heller anställas vid Rudolf Steiner Biblioteket eller det därtill knutna institutet."

Stiftelsen för Åbo Akademi fick alltså motta donationen. Allt började med upprättandet av ett Steinerbibliotek, där alla Steiners skrifter skulle ingå jämte böcker han hänvisat till. Som bibliotekarie för detta anställdes Olof Sundström från den I september 1957.

Hänvändelser från Stiftelsen till akademins konsistorium och $\mathrm{Hu}-$ manistiska fakulteten skedde bl.a. med tanke på en kommande professur. I humanistiska fakulteten väckte frågan om inrättandet av ett institut och Steinerbibliotek motstånd. I slutet av november I 957 utarbetade man en skrivelse som skickades vidare till konsistoriet, där man uttryckte allvarliga farhågor för att hela akademins vetenskapliga rykte skulle svärtas genom att "donationen står i tecknet av Rudolf 
Steiners antroposofi”. Om inte ändringar skulle ske i skrivelsen föreslår fakulteten ett avböjande av donationen.

I bestämmelserna för fonden nämns att det ska finnas en övervakare av donationens verkställande. Den som åtog sig den uppgiften var, som vi sett, H. W. Donner. Som ställföreträdande uttolkare av donationen fungerade professor Lars Erik Taxell (I 9I 3-20I3) vid Åbo Akademi.

Åbo Akademis konsistorium, som alltså bestod av alla professorer vid hela akademin, diskuterade vid sitt möte den 30 november 1957 humanistiska fakultetens hänvändelse och bekymmer över donationen och beslöt att utse en kommitté som skulle diskutera donationsbrevets formuleringar med uttolkaren professor H. W. Donner. I kommittén satt professorerna Sven Lindman, Oscar Nikula, Helmer Tegengren och överbibliotekarien Carl-Rudolf Gardberg.

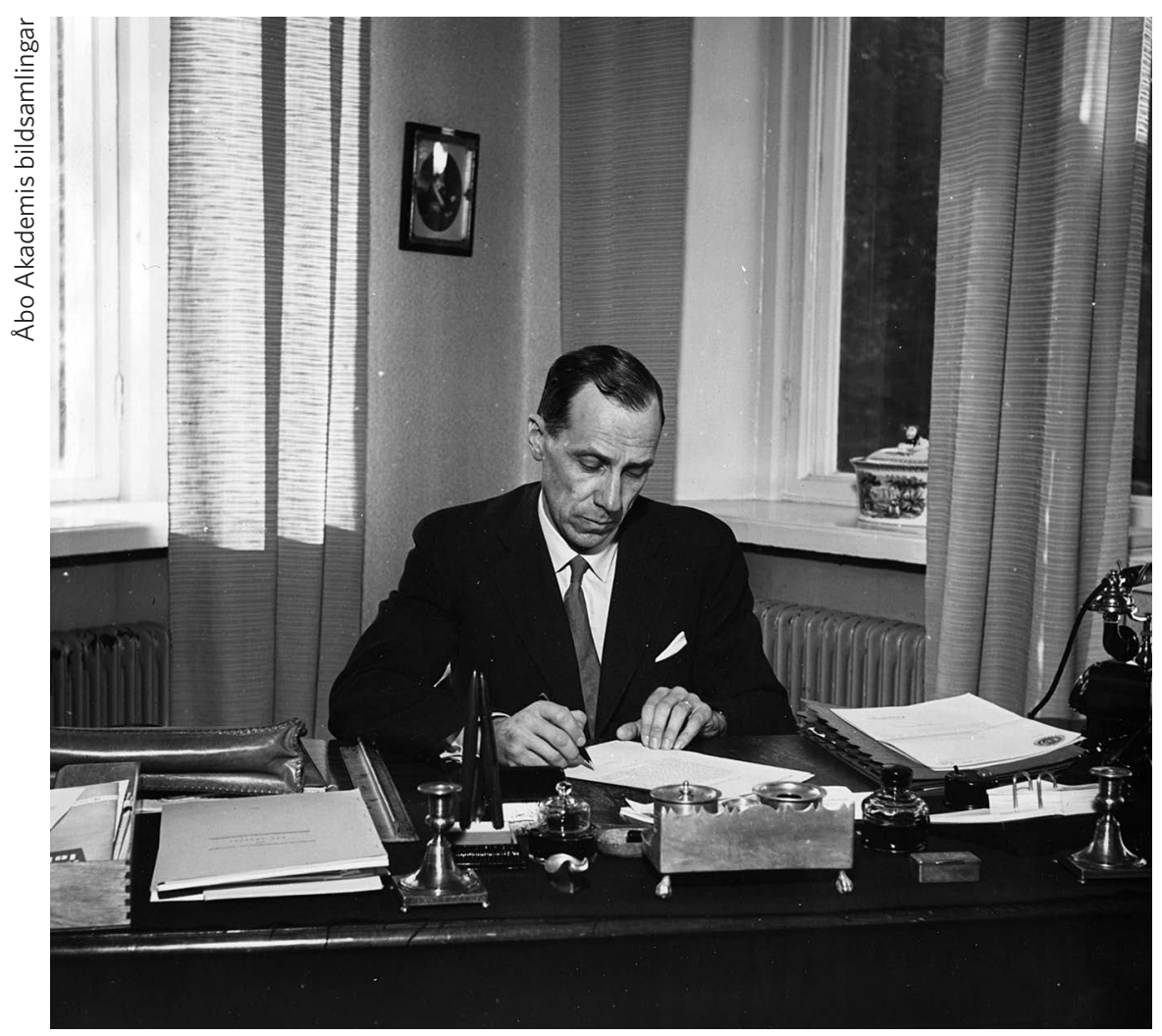

Lars Erik Taxell (1913-2013). 


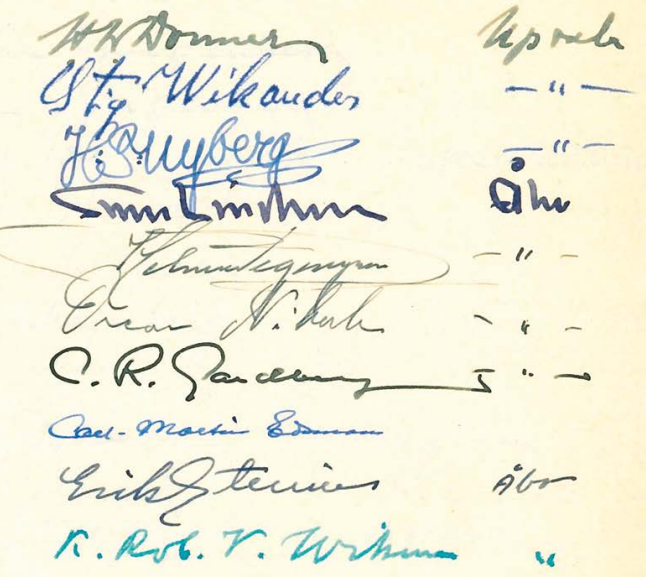

Namnteckningar ur Donnerska institutets gästbok, våren 1958, kommittén som arbetade med donationens förverkligande: H. W. Donner, Stig Wikander, H. S. Nyberg, Sven Lindman, Helmer Tegengren, Oscar Nikula, Carl-Rudolf Gardberg, Carl-Martin Edsman, Erik Stenius, K. Rob. V. Wikman.

H.W. Donner reagerade med en skrivelse den I februari 1958 vari han i något skarpa ordalag framför att institutet aldrig varit tänkt att vara ett språkrör för antroposofin och att vetenskapligheten aldrig varit ifrågasatt. En diskussion mellan H.W. Donner, dennes ställföreträdare professor Lars Erik Taxell och representanterna för akademin ägde rum den 15 mars 1958. Följande dag hade man åter ett möte och då beslöt man att anta en skrivelse benämnd "Grunder för uppbyggandet av Donnerska institutet för religionshistorisk och kulturhistorisk forskning”. I den skrivelsen presenteras många punkter om hur institutet skulle skötas. Här nämns interimsstyrelsen som alltså skulle bestå av H.W. Donner, professor Lars Erik Taxell, en representant för humanistiska fakulteten samt en annan skandinavisk vetenskapsman jämte de två sistnämndas ställföreträdare. Överbibliotekarien skulle ingå. Utöver detta talas det om uppgifter, bl.a. bokanskaffningar och stipendier. 
Som uppgifter på längre sikt nämns bl.a. att på sträng vetenskaplig grund främja religionshistorisk och kulturhistorisk forskning genom en personlig professur. En sådan professur skulle tillsättas genom kallelseförfarande men också kunna tillsättas med sakkunnigförfarande för att garantera kvaliteten. Bibliotekets namn skulle vara Steinerbiblioteket och på engelska The Steiner Memorial Library. Denna skrivelse kan sägas vara grunden för stadgarna som senare tillkom.

Som vi sett hade H. W. Donner och Lars Erik Taxell avgörande roller vid förverkligandet av Donnerska institutet. H. W. Donners efterträdare vid Åbo Akademi Nils Erik Enkvist bedömer i sin minnesskrift över H. W. Donner att denne gjorde en av de största insatserna i samband med grundandet och förvaltningen av Donnerska institutet. H. W. Donner fick ett avgörande inflytande över donationens verkställighet genom att kraftigt betona att forskningen skulle ske efter helt vetenskapliga principer

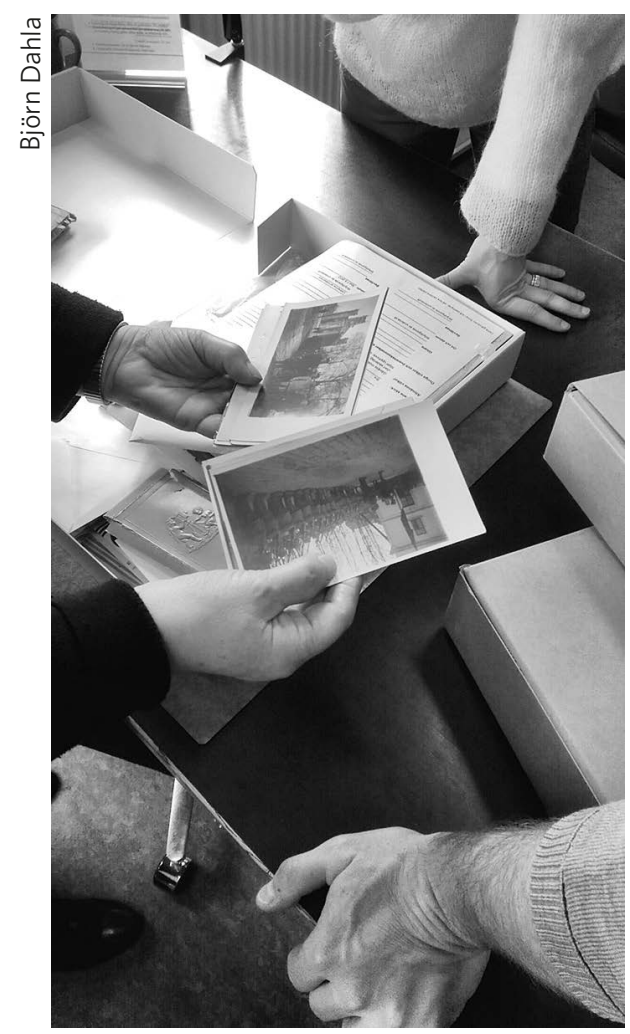
och metoder. Härvid kunde han hänvisa till vad donatorerna själva skrivit om saken. Även om dessa beundrade Rudolf Steiners insatser"som en andens banbrytare och spridare av ljus i ett stort mörker, sågo de i honom dock en ensam fackelbärare vars verk var i behov av verifiering och utbyggnad genom målmedveten vetenskaplig forskning på mysticismens område”.

Donnerska institutets personal besöker Åbo Akademis biblioteks bildsamlingar i april 2016. 
Vetenskapligheten är tydligt nämnd i bestämmelserna och till detta har man alltid kunnat hänvisa.

Tidigare professorn i praktisk teologi vid Åbo Akademi och biskopen i Borgå stift, tillika ordförande för Stiftelsens Delegation G. O. Rosenqvist fick i början av år 1958 kännedom om formuleringarna rörande teologerna. I ett brev till Lars Erik Taxell av den 20 mars I 958 skriver han: "bestämmelsen att vederbörande vid den Donnerska institutionen inte får inneha teologisk examen [är] en diskriminering av de teologiska studierna och examina och därmed en kränkning av en av Akademiens fakulteter." Han framför tydligt ett hot om att avgå som ordförande för Delegationen för Stiftelsen för Åbo Akademi. Det förverkligades emellertid aldrig, eftersom han fick ta del av H. W. Donners kompletteringar av skrivelsen.

I ett uttalande till interimsstyrelsen säger H. W. Donner att formuleringarna rörande teologerna inte får tas bokstavligt. "Vad donator avsåg --- var att förhindra intrång på institutets verksamhet från sådant dogmatiskt tänkande som vilar på förutfattade meningar. I själva verket var all dogmatik honom motbjudande."Vidare sägs här att "i den mån undervisning bedrives, skall denna äga rum under humanistiska fakultetens auspicier". I minnesskriften över H. W. Donner framhåller Enkvist vidare att Donner hade "en klar uppfattning om vilka slag av forskning som bäst befrämjade institutets syften. Med fast hand styrde han institutets första steg i slutet på 50-talet och början på 6o-talet och ledde dess styrelse till sin död”. 


\section{Från interimsstyrelse till ordinarie styrelse}

År 1958 upprättades en interimsstyrelse för Olly och Uno Donners fond. Dess första möte hölls på Stiftelsen för Åbo Akademi den 6 oktober I 958. I denna styrelse satt från Uppsala universitet professor H. S. Nyberg och som hans ställföreträdare preceptor, senare professor Carl-Martin Edsman. Nyberg var vida känd som specialist på semitiska språk. Edsman var religionshistoriker. Från Åbo Akademis sida var professor Helmer Tegengren med jämte ställföreträdaren professor Erik Stenius. Den förre var professor i nordisk kulturhistoria och folklivsforskning och den senare i filosofi. Dessutom var överbibliotekarien fil.dr Carl-Rudolf Gardberg med. Ordförande var H. W. Donner och hans ställföreträdare var professorn i privaträtt vid akademin Lars Erik Taxell. Som framgår fanns representanter för Uppsala universitet och för Åbo Akademi, liksom företrädare för Stiftelsen för Åbo Akademi, en representant för vardera instansen och med ställföreträdare. Redan nu blev kutymen den att ställföreträdarna hade närvaro- och yttranderätt i styrelsen, en praxis som fortsatt intill våra dagar. Dessutom var det viktigt att biblioteksväsendet representerades, eftersom institutet i början huvudsakligen var ett bibliotek. Provisoriskt hade man inlett verksamheten redan den I september I 957 med upprättandet av Steinerbiblioteket. Utrymme bereddes i akademibibliotekets västra flygel.

För att få fart på bokanskaffningarna kontaktade man olika specialister. Professor emeritus K. Rob. V. Wikman fick i uppdrag att komma med förslag till inköp av litteratur om folkliga trosföreställningar, professor Stig Wikander, Uppsala, kontaktades angående litteratur om iransk och indisk mystik och professor Carl-Martin Edsman rörande mystiken i fjärran Östern. Bibliotekarie var Olof Sundström med fast tjänst. Han hade anställts I september I 957 med uppgift att 
Carl-Martin Edsman var född den 26 juli 1911 i Malmberget, Gällivare. Han studerade teologi vid Uppsala universitet och i Paris. Han blev teol.kand. 1935, teol.lic. 1938 och teol.dr 1941. Hans doktorsavhandling bär titeln Le baptême de feu. I Lund studerade han vidare och blev filosofie doktor där 1949. Han var också prästvigd, och har omfattande publikationer på religionshistoriens och teologins område. År 1950 blev han professor i religionshistoria vid Uppsala universitet och han pensionerades 1978. Han dog den 22 januari 2010 i Uppsala. (Bild: Uppsala-Bild / Upplandsmuseet, 1967)

huvudsakligen handha den antroposofiska litteraturen. Hans hustru Margarete Sundström erhöll medel för att införskaffa sådan litteratur som åberopas av dr Steiner.

Den 6 oktober 1958 anställdes docenten, senare överbibliotekarien Olof Mustelin som t.f. bibliotekarie. Den första maj I 959 fick fil.mag., senare professor Sixten Ringbom anställning som bibliotekarie. Då han i oktober I 959 var i England för studier anställdes fil.mag., senare docenten och överbibliotekarien Siv Storå. Biblioteket var ett referensbibliotek, varför utlåning skedde i ytterst ringa grad.

Under åren efter donationsbrevets upprättande arbetade akademins och Stiftelsens organ vidare med villkoren. I november 1959 nådde så handlingarna slutligen Stiftelsens för Åbo Akademi delegation. Vid dess ordinarie möte den I6 november I 959 förelåg alla handlingar om donationen, alla dess förvecklingar och klargöranden. Man fastställde stadgarna och utsåg representanter för delegationen i institutets styrelse. Den 16 november 1959 kan alltså ses som ett egentligt grundläggningsdatum för Donnerska institutet.

Den 2 april r 96o sammanträdde den ordinarie styrelsen första gången. Samma personer som i interimsstyrelsen satt nu med. Man hade fătt 


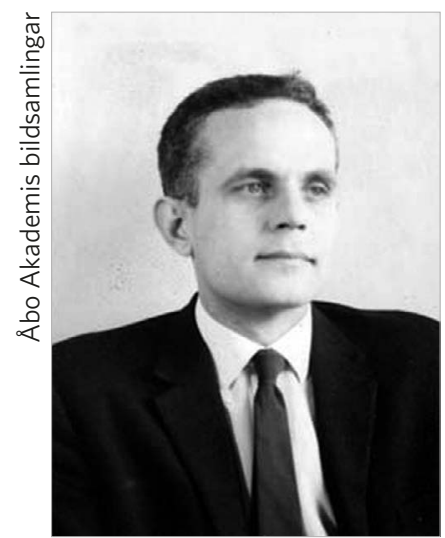

Sixten Ringbom (19351992) var bibliotekarie vid DI i olika repriser från år 1959. Han utnämndes till professor i konsthistoria vid Åbo Akademi år 1968. stadgar för institutet jämte tillämpningsbestämmelser. Till dessa hörde bl.a. att biblioteket skulle vara ett s.k. presensbibliotek som endast $i$ undantagsfall lånade ut böcker. Därför var det viktigt med en ordentlig läsesal. Institutet höll nu till i huvudbibliotekets ena flygel i mycket begränsade utrymmen.

Man antecknade även att man var intresserad av att fästa professor Helmer Ringgren i Uppsala till institutet. Ett sakkunnigförfarande om dennes professorskompetens skulle genomföras. Hösten I 96 I skulle professor Carl-Martin Edsman

Margarete Sundström var född i Tyskland år 1900. I brist på objektiva fakta om hennes liv kan några minnesbilder återges. Fru Sundström förekom flitigt på Donnerska institutet under 1960- och 1970-talen. Hon hade tidvis anställning. Hennes uppgift var huvudsakligen att värna om Steineriana. Hon talade en blandning av tyska och svenska. Hon var mycket talför och studenterna fick höra en hel del om Dr Steiner och hans fru, mycket om astralkroppar och naturmedicin. Ännu på 1970-talet fanns inte så mycket av naturmedicin tillgänglig hos oss, vilket hon livligt beklagade. Hon var en väldigt stor beundrare av Dr Steiner och betraktade honom som "hellsehend". Hon hade studerat eurytmi och recitationskonst för fru Steiner och vid större festligheter på Donnerska institutet hände det sig att hon framträdde med recitation. Med en mycket speciell recitationston framförde hon då gärna Pater noster på latin och även Johannesprologen på grekiska. Vi kallade henne ofta "Överantroposofissan". Via henne kom studenterna på den tiden relativt nära den anda som antroposofin önskade förmedla. Fru Sundström dog våren 1978. Vid hennes begravning som genomfördes i Uppståndelsekapellet på tyska med en präst från Christengemeinschaft framförde även Holm en Bachkoral som solosång. 
vistas vid institutet och bidra till skapandet av riktlinjer för bokanskaffningarna. Man planerade även ett symposium I 962 över temat shamanism.

Ett flertal personer fick stipendier de första åren, de var för det mesta graduerade inom andra ämnen än religionshistoria. Bland dem fanns Patrick Bruun, Holger Thesleff, Johan Chydenius, Birgit Klockars, Mårten Ringbom, Arne Runeberg, Sixten Ringbom, Johannes Salminen, Nils Storå och Rolf Westman. Även K. Rob. V. Wikman fick betydande anslag för sin forskning och för sitt bidrag till bokanskaffningarna vid institutet. Carl-Martin Edsman anlita-

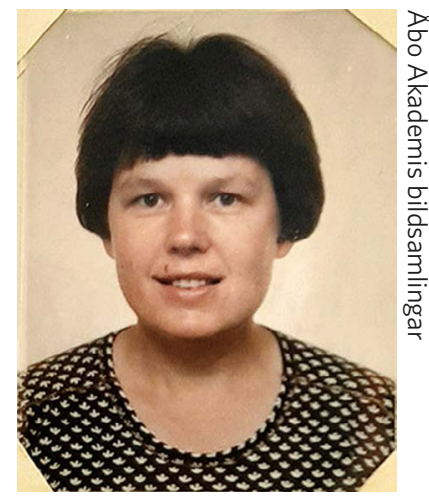

Siv Storå (f. 1934) var amanuens vid DI 19591973. Sin huvudsakliga karriär gjorde hon vid Åbo Akademis bibliotek, bl.a. som överbibliotekarie 1995-1998. des för planeringen av bokanskaffningarna, vilket är väl dokumenterat i handlingarna. Först i slutet av i 960-talet och senare fick ämnet elever som kunde ansöka om stipendier.

Den 4 juni 1962 avled Olof Sundström, efter att ha lidit av ohälsa en längre tid. Han var född 28 november I 899 . Före tjänsten vid institutet hade han varit aktiv inom scoutrörelsen, inom Arbetets Vänner samt ägnat sig åt konstnärlig och pedagogisk verksamhet i Rudolf Steiners anda. Under sin tid vid institutet lade han grunden till den antroposofiska avdelningen. "Hans grundliga antroposofiska utbildning och djupa förtrogenhet med dr Steiners tankevärld gjorde hans insatser för biblioteket ovärderliga”, framhåller man i årsberättelsen r 96 I-r 962. Hans hustru Margarete Sundström hade anhållit om pension och detta beviljades. 


\section{Tiden med professur}

\section{Ringgrens tid}

Höstterminen I 962 började med nya krafter. Ett sakkunnigförfarande hade genomförts för Helmer Ringgren. Sakkunniga var professorerna Erland Ehnmark, Lund, Rudi Paret, Tübingen och H. S. Nyberg, Uppsala. Deras utlåtanden var genomgående positiva. Vid humanistiska fakulteten var man beredd att införliva en ny professur med kallelseförfarande och bad kansler om en utnämning. Ringgren knöts till institutet från den I september 1962 och blev omedelbart också föreståndare för institutet. Ringgren föreläste hösten I 962 över en grundkurs i religionshistoria baserande sig på hans och Åke V. Ströms mycket använda bok Religionerna $i$ bistoria och nutid. Deltagarantalet uppgavs vara I 2, samma antal som de nyantagna teologie studerandena,

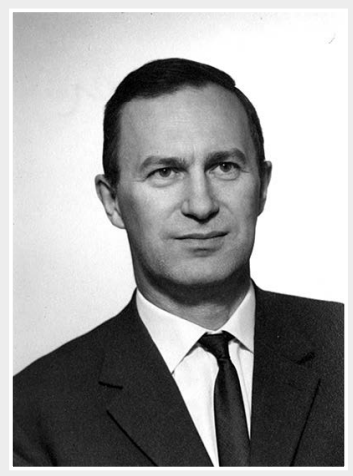

Karl Helmer Ringgren var född på
Gotland den 20 november 1917. Han tog
studentexamen i Stockholm 1936 och
disputerade i Uppsala 1947 för teologie
doktorsexamen. Han var även filosofie
licentiat. Han utnämndes 1947 till docent
i religionshistoria med religionspsykologi
vid Uppsala universitet. Åren 1960-1962
var han professor i Old Testament
interpretation vid Garrett Biblical Institute i Evanston, Illinois, USA, och 1962-1965 innehade han den personliga professuren i religionshistoria vid Åbo Akademi. Därefter innehade han professuren i gammaltestamentlig exegetik vid Uppsala universitet. Han avled den 26 mars 2012 i Uppsala. (Bild: Åbo Akademis bildsamlingar) 


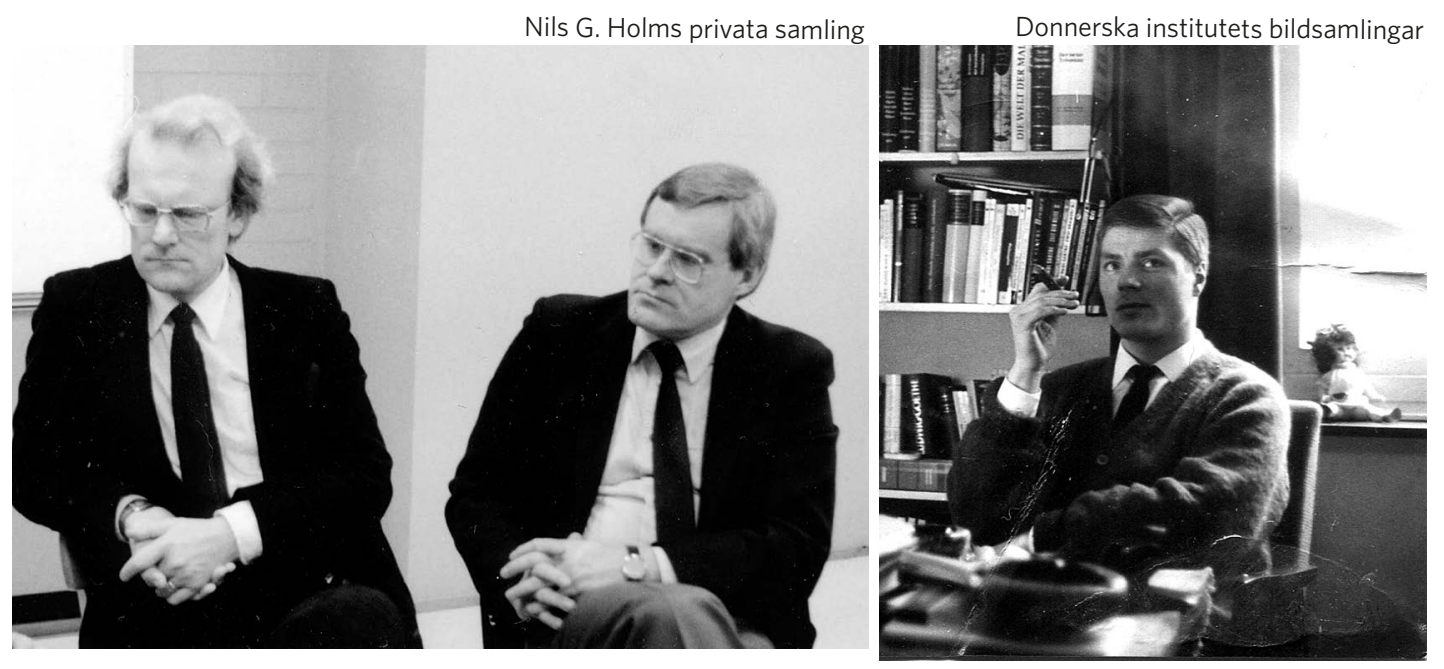

Från vänster: Professorerna Nils G. Holm ( bo Akademi) och Lauri Honko ( bo universitet), 1982. Föreståndare Tore Ahlbäck, 1980-tal.

till vilken grupp också Tore Ahlbäck och Nils G. Holm hörde. I övrigt föreläste Ringgren över hellenistisk religion, bl.a. mysteriereligionerna. Omdömet om honom bland studerandena var genomgående mycket positivt. Under många år framöver hade Ringgren avgörande roller i styrelsen för Donnerska institutet. Han föreläste även som pensionär på I 980- och I 990-talen över islam vid religionsvetenskapen i Åbo.

En sak som fått bestående betydelse för religionsvetenskapen i Finland var att Ringgren tog initiativ till grundandet av Religionsvetenskapliga sällskapet i Finland. Det skedde i slutet av i 963. Grundande medlemmar var förutom Ringgren professorerna Lauri Honko, Martti Haavio och Erik Allardt. En följd av grundandet blev tidskriften Temenos: Nordic Journal of Comparative Religion som huvudsakligen drevs av Honko i flera år.

Hösten 1962 påbörjades även en annan viktig verksamhetsform för institutet, och det var symposierna. I ungefär ett års tid hade planerna på ett symposium bearbetats. Temat skulle vara shamanismen. Huvudansvariga för arrangemangen var Carl-Martin Edsman och Helmer Tegengren. Symposiet hölls den 6-8 september 1962. Deltagarantalet uppgick till 42 . Efter symposiet blev det aktuellt att 


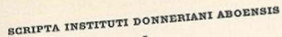

STUDIES IN SHAMANISM

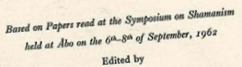
CARLMARTIN EDSMAT втоскном utge föredragen i skriftlig form. Man beslöt att påbörja en skriftserie kallad Scripta Instituti Donneriani Aboensis. Första volymen blev temat med shamanism.

År 1964 skulle man igen anordna ett symposium, denna gång över temat ödestron. Detta symposium hölls den 7-9 september I 964 , med 39 deltagare. Det kan nämnas att framför allt genom Helmer Tegengrens försorg ställde flera företag i Åbo upp med bidrag, huvudsakligen så att de stod för luncharrangemang, vilka kunde vara överdådiga.

Man arbetade också med reglemente för föreståndaren för institutet och ett reglemente för stipendieutdelning. Då det gäller stipendierna hade man vänt sig till humanistiska fakulteten och bett om utlåtande. Man gjorde skillnad mellan stipendier till färdigt utbildade vetenskapsmän och yngre sådana. Fakulteten fick i uppdrag att uttala sig om de yngre vetenskapsidkarna.

Det bör nämnas att institutet också kom i åtnjutande av ekonomiska bidrag från en fond i Stockholm kallad Stiftelsen Academica som även förvaltade Olly och Uno Donners medel. Man hade också gästföreläsningar vid institutet denna tid. Professor Geo Widengren från Uppsala höll föreläsning i november r 963 och båda docenterna från Uppsala Haralds Biezais och Sven S. Hartman vårterminen i 964.

Professor Ringgren var synnerligen språkbegåvad. Han lärde sig finska så han kunde läsa vetenskaplig text på det språket. Tyska, franska, engelska var självfallet språk han behärskade suveränt, förutom de klassiska språken grekiska och latin. De forna främreorientaliska språken var han väl insatt i. Hans kompendium i hebreisk grammatik har lästs av flera generationer teologer. Arabiska var honom inte heller främmande.

En liten intressant minnesbild är morgonen den I maj I 963. Teologie studerande med bistånd av medlemmar i Kristliga Studentföreningen vid Åbo Akademi (KSÅA) hade för vana att tidigt den I maj 
gå en runda till professorerna och lärarna vid teologiska fakulteten och sjunga de vanliga vårsångerna, bl.a. "Vintern rasat". Den I maj I 963 stod man också utanför familjen Ringgrens dörr och tog dem helt på säng med sången. Dörren öppnades försiktigt och där stod paret Ringgren iförda morgonrockar, mycket förvånade. De frågade vad de skulle göra och studenterna svarade att ingenting behövde göras. Studenterna hastade vidare till andra lärare. Annars var kutymen den att man blev inbjuden och ett glas mjöd med struvor serverades.

Redan den io november I 964 lämnade Ringgren en skrivelse till humanistiska fakulteten

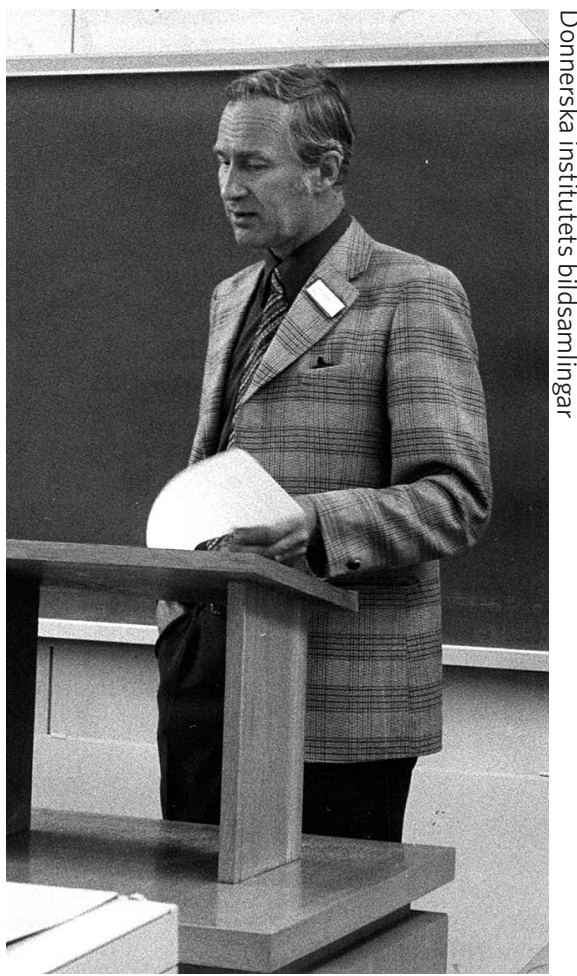

Helmer Ringgren föreläser på konferensen IAHR i Åbo, augusti 1973. om avsked. Han hade blivit kallad till den gammaltestamentliga professuren vid Uppsala universitet. Ringgren avgick 30 juni 1965. Man hade även ett namn på möjlig efterträdare till Ringgren i Åbo. Det var docenten Sven S. Hartman i Uppsala. Ett sedvanligt sakkunnigförfarande föranstaltades.

\section{Hartmans tid}

Docenten Sven S. Hartman tillträdde som professor och föreståndare för institutet den r juli r 965. Han föreläste över den allmänna religionshistorien samt över preislamsk iransk religion och religionspsykologi. Han började även med seminarieverksamhet. Holm och Ulrika Wolf (senare professor Wolf-Knuts) tillhörde den lilla grupp som studerade för honom denna tid. Studenterna fick höra väldigt mycket om 
Cinvat-bron i Zoroastrismen, som förde över från detta livet till det tillkommande. Bron var vass som en kniv för dem som var orättfärdiga och bred och lättpasserad för dem som var rättfärdiga. På andra sidan livet mötte så en änglagestalt, daena, och tog hand om den avlidnes ande. Studenterna fick också höra mycket om änglaväsen och att hela konceptet med änglar i flera religioner går tillbaka på den forniranska teologin.

Holm läste upp litteraturkursen till laudatur (tre betyg enligt rikssvensk benämning) och minns att hela kursen var på franska, bl.a. Claude Lévi-Strauss stora verk Les Mythologies. Det var ganska vanligt att flera av de anställda vid institutet åhörde föreläsningarna.

Den 22 februari 1966 tog man i bruk nya lokaler i det s.k. Tryckerihuset, på Biskopsgatan I7-Gezeliusgatan 2. Det totala utrymmet var cirka 250 kvadratmeter. Den officiella invigningen skedde den Io september I 966 sedan man fătt en del nya möbler och inventarier. Detta skedde i samband med symposiet. Anställda denna tid var

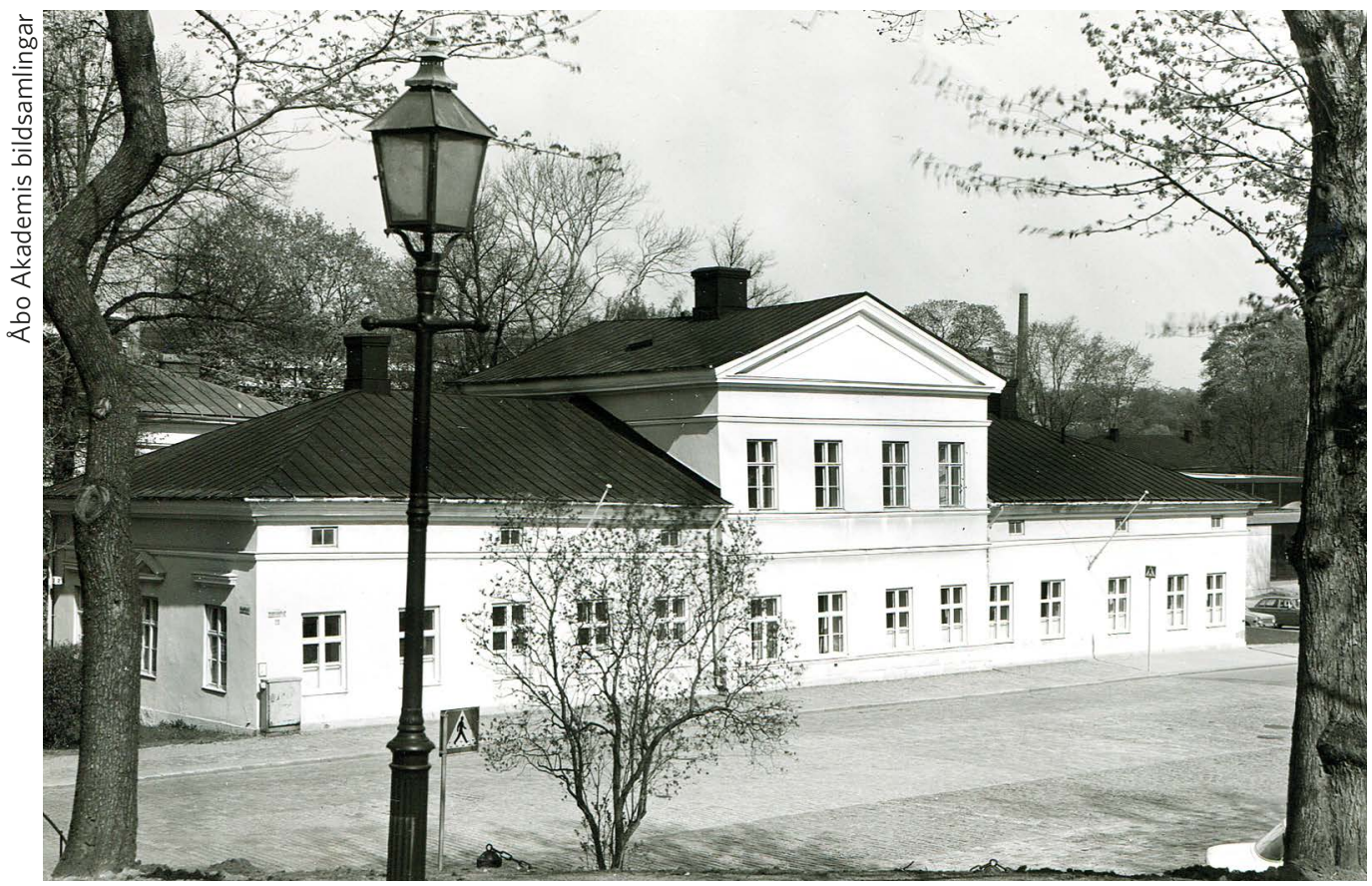

Tryckerihuset på Biskopsgatan 17-Gezeliusgatan 2 inrymde Donnerska institutet åren 1966-2005. 


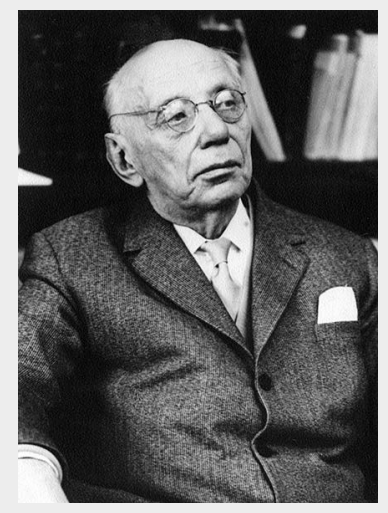

Karl Robert Villehad Wikman var född i

Vasa den 20 maj 1886. Han blev student vid Vasa svenska lyceum 1906, och studerade vid Helsingfors universitet och vid Åbo Akademi. Han blev filosofie doktor vid akademin 1937 och docent $\mathrm{i}$ sociologi samma år. Han examinerade och ledde seminarieövningar i sociologi under flera år, och hade en mängd läraruppdrag vid folkhögskolor och olika institut. Bland annat var han föreståndare för Institutet för nordisk etnologi, huvudutgivare av Finlands svenska folkdiktning och medlem av redaktionskommittén för tidskriften Budkavlen. Han hade medlemskap i en mängd lärda samfund. Han avled 14 maj 1975. (Bild: Åbo Akademis bildsamlingar)

Sixten Ringbom, Siv Storå, Märta Söderholm, Birgitta Lundberg samt Margarete Sundström. Knappt 2000 volymer hade accessionerats, varav 430 var gåvor. Sammanlagt hade man något över I 5 ooo volymer i biblioteket, och 27 I besök hade antecknats.

Den 8-io september i 966 anordnades ett symposium med temat kulturkontakt, religionsmöte, synkretism med knappt 50 deltagare. Huvudansvariga var professorerna Edsman, Ringgren och Hartman. Föredragen skulle ingå i skriftserien. K. Rob. V. Wikman fyllde 80 år i juli och man bidrog till en festskrift. Bland annat professor emeritus Otto Andersson var aktiv i arbetet med denna.

År 1967 antog man instruktioner för amanuens- och underbibliotekariebefattningarna vid institutet. Det kan nämnas att för amanuensbefattningen krävdes filosofiekandidatexamen med ämnen som religionshistoria, konsthistoria, nordisk kulturhistoria och folklivsforskning. Dessutom skulle man ha styrkt förmåga att förstå vetenskaplig text på engelska, franska och tyska samt försvarlig förmåga att tala ett av dessa språk. Utöver detta skulle man kunna translitterera 


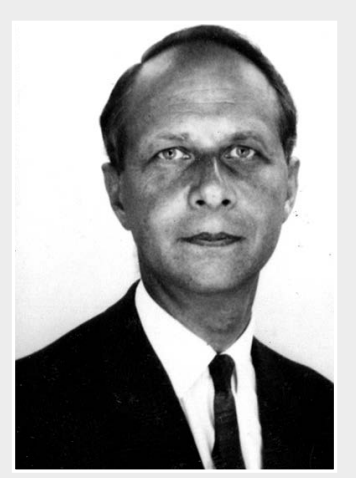

Sven Samuel Hartman var född den 22 juni 1917 i Högbo församling i Gävleborgs län. Han tog studentexamen vid Högre allmänna läroverket på Kungsholmen i Stockholm. Han studerade vid Uppsala universitet och blev filosofie licentiat och teologie doktor. Disputationen ägde rum i november 1953. Han var timlärare vid Fjellstedtska skolan i Uppsala och blev docent i religionshistoria med religionspsykologi vid Uppsala universitet. I början av 1960-talet var han lektor vid Högre allmänna läroverket i Haparanda. Han hade flera undervisningsuppdrag vid olika institutioner bl.a. i Köpenhamn och Uppsala. Den 1 juli 1965 blev han professor i Åbo och föreståndare för Donnerska institutet. Han avgick sommaren 1969 och blev professor i religionshistoria vid Lunds universitet. Han avled den 2 april 1988. (Bild: Åbo Akademis bildsamlingar)

text på ryska eller något av de vanligaste orientaliska språken. Bokoch bibliotekskunskap krävdes också och den kompetensen erhöll man efter studier för överbibliotekarien. Så sköttes biblioteksvetenskapen den tiden.

Under vårterminen 1967 utkom de två första volymerna i institutets skriftserie Scripta Instituti Donneriani Aboensis, några år försenade. Upplagan var I ooo exemplar och distribuerades av förlaget Almqvist \& Wiksell i Sverige. Den 7-9 september 1968 hölls ett symposium med temat mystiken. Ett 40-tal deltagare ställde upp. Alla föredrag hölls i de två auditorierna Brahe och Flora i det nyöppnade Sibeliusmuseet. Kommittén som ordnade symposiet bestod av professorerna Edsman, Hartman, Ringgren och Tegengren.

Professor Sven S. Hartman avgick från professuren den I augusti I 969. Nyanställda vid institutet var teol.mag. Nils Martola och hum.kand. Ulla Rosenberg. Hösten 1969 sköttes undervisningen i religionshistoria så att professor Lauri Honko vid det finskspråkiga 
Åbo universitet trädde till och också ansvarade för metodundervisningen. Professor Jussi Aro från Helsingfors höll en kurs över islam.

\section{Biezais tid}

Som tredje professor vid Donnerska institutet fungerade Haralds Biezais från den 19 januari 1970. Han var då redan fyllda 60 år. Han kom ursprungligen från Lettland. Under andra världskriget flydde han till Sverige och upptog studier i Uppsala. I Åbo höll han första året föreläsningar över Induskulturen samt seminarieövningar. Under I 970-talet föreläste Biezais vidare över religionspsykologi, religionssociologi och ateismens psykologi.

I och med Biezais tillträde skedde en markant ökning av studerande och seminarierna fick ett rykte som mycket fruktbärande. Metodfrågor och teorier avhandlades ivrigt. En uppgång för hela ämnet skedde. Vid den här tiden höll man seminarierna kl. I 8-20, och det fördes protokoll vid seminarierna. Protokollböckerna finns bevarade och är rätt intressant läsning idag. Det var mycket vanligt att man efter seminarierna gick till en restaurang för att äta lite. Hämeenportti vid Tavastgatan

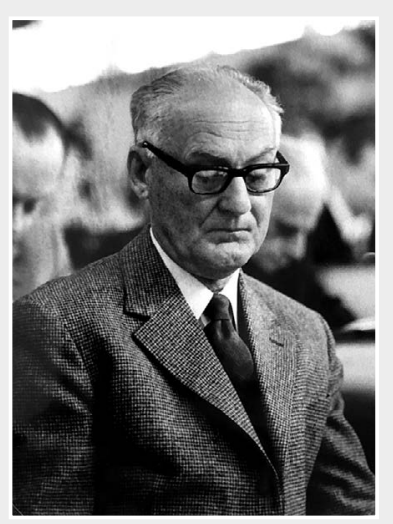

Haralds Teodors Biezais var född den 10 juli 1909 i Lestene, Lettland. Han blev teologie kandidat vid Lettlands universitet 1932 och prästvigdes i Lettlands evangelisk lutherska kyrka. Han var även kyrkoherde i Gramzda församling i nästan tio år. Han flydde till Sverige 1944 och fortsatte sina studier vid Uppsala universitet. Han blev både teologie och filosofie doktor. Han tjänstgjorde som lärare vid olika läroverk i Sverige under en tioårsperiod. År 1970 utnämndes han som professor i religionshistoria vid Åbo Akademi, och avgick från tjänsten den 1 juli 1978. Han dog i Sverige år 1995. (Bild: Donnerska institutets bildsamlingar) 
i Åbo var den mest frekventerade restaurangen. Något ovanligt var att professor Biezais ofta lät sig bjudas på maten av de relativt medellösa studenterna, i alla fall i början av seminarieverksamheten. Senare blev det kutym att han bjöd respondenten på vin och ibland också maten. Allt mellan himmel och jord kunde avhandlas vid dessa sessioner. Man kom något närmare varandra, också professorn. Studerande från Sverige började också dyka upp. Tre namn från tidigt I 970-tal är Magnus Magnusson, Louise Skytte och Thomas K:son Hultberg.

Intressant är att detta seminarium lett av Biezais genererat sex professorer i skilda ämnen (Holm, Ulrika Wolf-Knuts, KarlGustav Sandelin, Tage Kurtén, Kaj Björkqvist, Susan Sundback), en

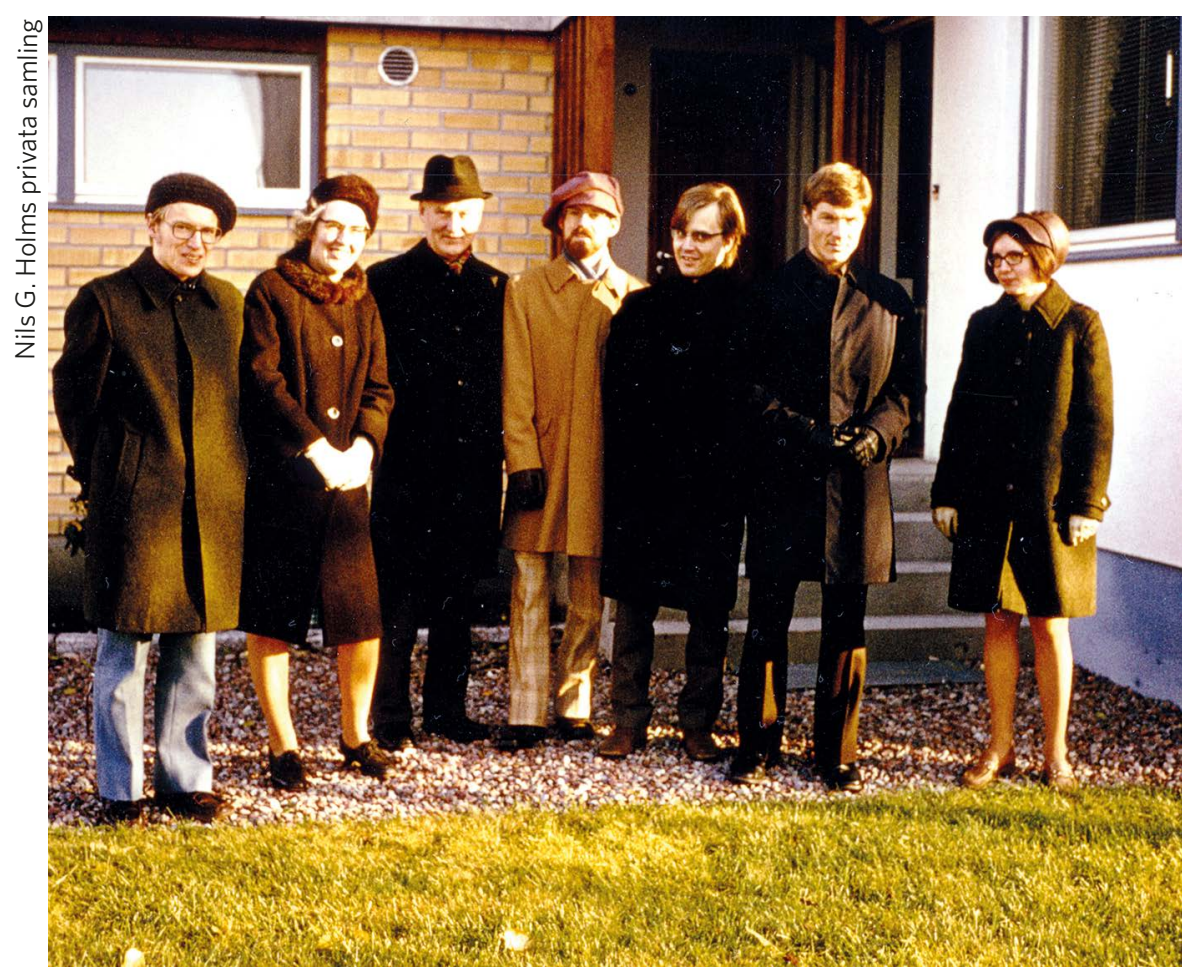

Högre seminariet i religionshistoria gjorde exkursioner till andra orter bl.a.

Mariehamn och Åminneborg i Malax. Här står några deltagare framför ingången till Nils Martolas kaplansboställe i Mariehamn hösten 1972. Från vänster: Pertti Järvinen, Louise Skytte (Sverige), Haralds Biezais, Thomas K:son Hultberg (Sverige), Nils Martola, Tore Ahlbäck och Ulrika Wolf-Knuts. Nils G. Holm var också med och tog förmodligen fotografiet. 


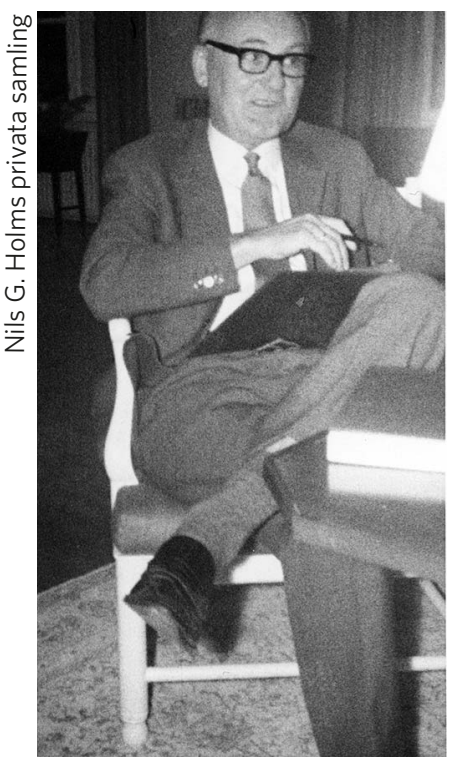

Haralds Biezais.

överbibliotekarie (Tore Ahlbäck) och en gymnasierektor (Bertel Wahlström). Det är ganska anmärkningsvärt i sig.

När det begav sig kunde professor Biezais vara mycket besvärlig med studenterna av delvis outgrundliga orsaker. En sak var dock att vid denna tid måste studenterna betala in en summa på huvudkansliet och vid tentamen förete kvittot för professorn. Senare fick professorn en viss del av inbetalningen som lönepåslag. Det hände rätt ofta att det uppstod problem med denna betalning vid tentamen för Biezais.

Professor Biezais var specialist på baltisk religion och skrev flera betydande arbeten om detta. Här kan nämnas Die Gottesgestalt der lettischen Volksreligion och Die himmlische Götterfamilie der alten Letten.

Den 6-8 september 197 I hölls ett symposium med temat "Myten om staten". Som understödjande institutioner och företag nämns Åbo stad, Åbo Akademi, Kansallis-Osake-Pankki, Sparbanken i Åbo, Valio Mejeriernas Centrallag, Ömsesidiga Försäkringsbolaget Sampo-Tarmo, P. C. Rettig \& Co, Oy Inka samt Ab Siljarederiet. Det var alltså avsevärt stöd symposiet fick. Detta var mest tack vare professor Tegengren, som hade goda relationer till företagsvärlden i staden. Symposiebidragen utkom som volym nr 6 i Scripta Instituti Donneriani Aboensis.

År 1972 var H. W. Donner fortfarande ordförande för styrelsen och L. E. Taxell hans ersättare. Från Uppsala var Carl-Martin Edsman representant och tillika viceordförande. Hans ersättare var Helmer Ringgren. Åbofakulteten

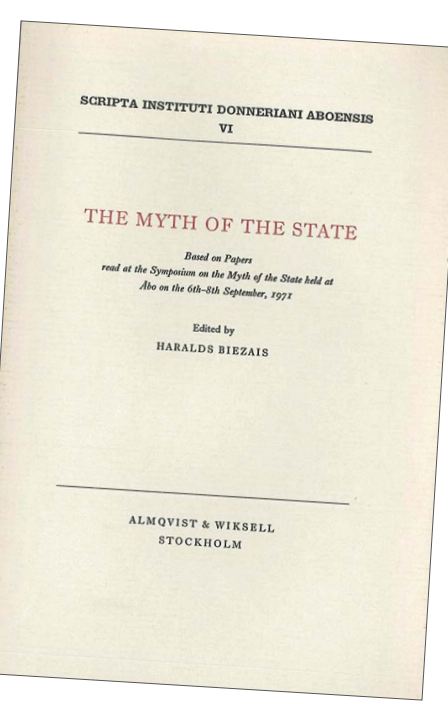




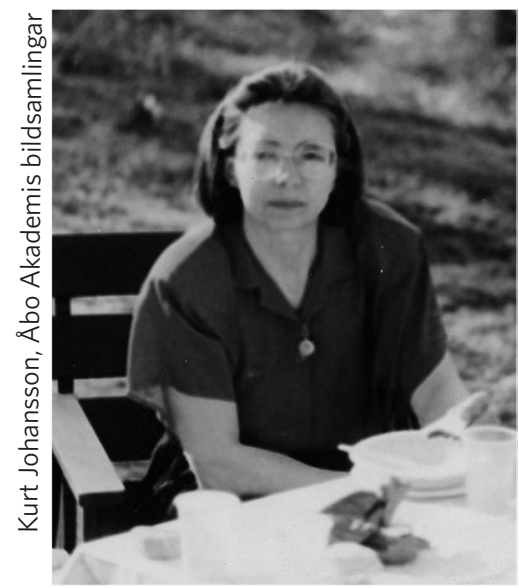

Ulrika Wolf-Knuts, bibliotekarie vid DI under 1970-talet.

representerades av Sixten Ringbom och Patrick Bruun. Överbibliotekarie Olof Mustelin satt också i styrelsen i egenskap av sakkunnig på biblioteksfrågor. Efter styrelsemötena åt man alltid en måltid. Den kunde vara relativt riklig vad mat och dryck beträffar och spänna över flera timmar. Det var en tradition som påbörjades av H. W. Donner själv. Något arvode har styrelsemedlemmarna aldrig uppburit.

Vid bibliotekets allmänna avdelning tjänstgjorde i olika repriser Siv Storå, Birgitta Lundberg, Ulrika Wolf-Knuts, Ulla Rosenberg (senare gift Andersson), Dan Holm, Maj-Lis Fagerholm, Johanna Bondas och Marja Niemi. I biblioteket infördes år I 972 I 7 I 9 volymer. Det sammanlagda bokbeståndet uppgick till 24 I 86 volymer. Besöksantalet var det största hittills: 22 I 7 .

År 1972 införde teologiska fakulteten ämnet religionshistoria som obligatoriskt ämne. Det betydde många fler studerande i detta ämne.

Extra undervisning med anslag från Donnerska institutet hölls av Holm över religionsfenomenologi och han ledde också övningar i studiet av religiösa texter. Ulrika Wolf-Knuts ledde övningar i studieteknik och hjälpmedel. (Wolf-Knuts disputerade r99 i i folkloristik och erhöll professuren i ämnet 2003.) Fil.dr Carl-Gustav Hartman föreläste över nutida religionsbildningar. Denna tid började de nyreligiösa rörelserna göra sig gällande.

Man utgav även denna tid halvårsvis nyförvärvslistor. Utrymmesbristen åtgärdades även år 1972 så att hela det s.k. tryckerihusets nedre våning kunde tas $\mathrm{i}$ bruk, något senare även andra våningen.

I början av r970-talet förberedde man sig vid Åbo Akademi för en större förvaltningsreform. Man strävade efter en mer demokratisk modell med valda representanter i de olika styrande organen. Detta föranledde att man inom Donnerska institutet behövde få veta om 
den nya modellen var förenlig med vad donatorerna fastställt. I tilllämpningsbestämmelserna för Donnerska institutet sägs tydligt ut att om Åbo Akademi skulle förlora sin ställning som självständig svenskspråkig högskola måste Donnerska institutet lösgöras från akademin. Då kunde pengarna i stället överföras t.ex. till Svenska kulturfonden. Lars Erik Taxell fick i uppdrag att reda ut denna sak och skrev en promemoria daterad 25 aug. I 970 där han noggrant går igenom saken och slutar med att konstatera att" $i$ dagens läge synes det mig inte motiverat att vidta konkreta åtgärder av definitiv natur". Han konstaterar också att "Det är likväl anledning att utreda på vilket sätt man bäst kan skapa en hållbar grund för framtida förändringar som kan bli nödvändiga." Hela saken återkom i slutet av I 970-talet då förstatligandet av akademin var aktuellt.

År 1972 inkom föreståndaren Biezais till styrelsen med en redogörelse för verksamheten vid institutet. Han konstaterade att det föreligger flera brister: böcker var okatalogiserade, stickordskatalogen var nedlagd sedan något år tillbaka och det vetenskapliga arbetet vid institutet hade inte kunnat ske såsom det var tänkt. Detta berodde enligt honom på att personalens kompetens var otillräcklig och att man koncentrerat sig alltför mycket på samlandet. $\mathrm{Nu}$ skulle det gälla att satsa mer på forskningen. För att nå detta ändamål borde en reorganisation av tjänsterna vid institutet ske. Professorn borde vara föreståndare, och därtill kom fyra tjänster: en underbibliotekarie med licentiatexamen, en amanuenstjänst, en assistent- och en sekreterartjänst. En kommitté tillsattes för att bereda ärendet.

Styrelsen beslöt senare att i stort följa förslagen. Föreståndaren drev även andra nyordningar vid institutet, vilket gjorde att de som tjänstgjorde där avsade sig uppdragen. Storå avgick den I januari I 974 och Lundberg den I oktober I974. På Storås tjänst förordnades under år I 974 teol.mag. Tore Ahlbäck och teol.mag. Nils Martola vardera på en halv tjänst. Tore Ahlbäck avgick emellertid hösten 1974 och tjänstgjorde som lektor i religionsvetenskap i Helsingfors. Han återkom dock redan från början av år I 975 och har sedan dess kontinuerligt varit anställd vid institutet ända till sin pensionering. Han blev visserligen 


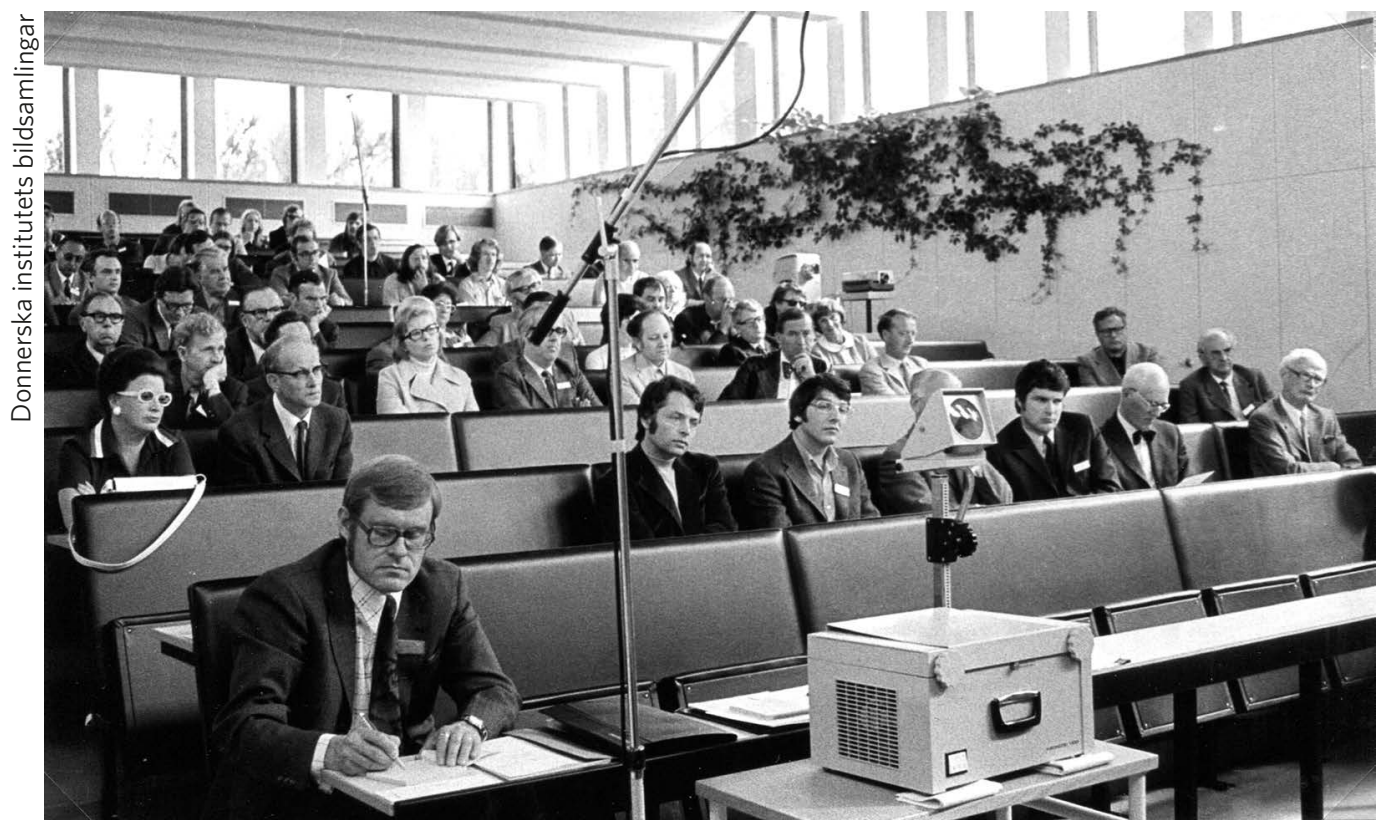

IAHR-konferensen i Åbo, augusti 1973. Föreläsning i Åbo universitets Fennicum-auditorium. I förgrunden Lauri Honko.

överbibliotekarie I 998 fram till 2009 men stod kvar som föreståndare för institutet.

Den 27-3 I augusti 1973 anordnades en stor metodkonferens i Åbo. Primus motor var professor Lauri Honko vid det finskspråkiga Åbo universitet. Konferensen skedde på uppdrag av IAHR (International Association for the History of Religions) i samarbete med Religionsvetenskapliga sällskapet i Finland och Donnerska institutet. Professor Biezais lämnade en redogörelse för konferensen till Donnerska institutets styrelse. Han framhåller att det organisatoriska fungerade perfekt och att många uttryckt sig så att konferensen var en milstolpe i den religionsvetenskapliga forskningen. Detta intygar även Ahlbäck och Holm som var bland de yngre i deltagargruppen. Alla stora namn var där, bl.a. Mircea Eliade, Zwi Werblowsky, Michael Pye, Eric J. Sharpe, J. van Baal, Ugo Bianchi, Åke Hultkrantz, Jacques Waardenburg, Melford E. Spiro och Ninian Smart. Konferensen hölls i den då relativt nyöppnade hörsalen i Fennicum på Henriksgatan 3, där 
Tiden med professur

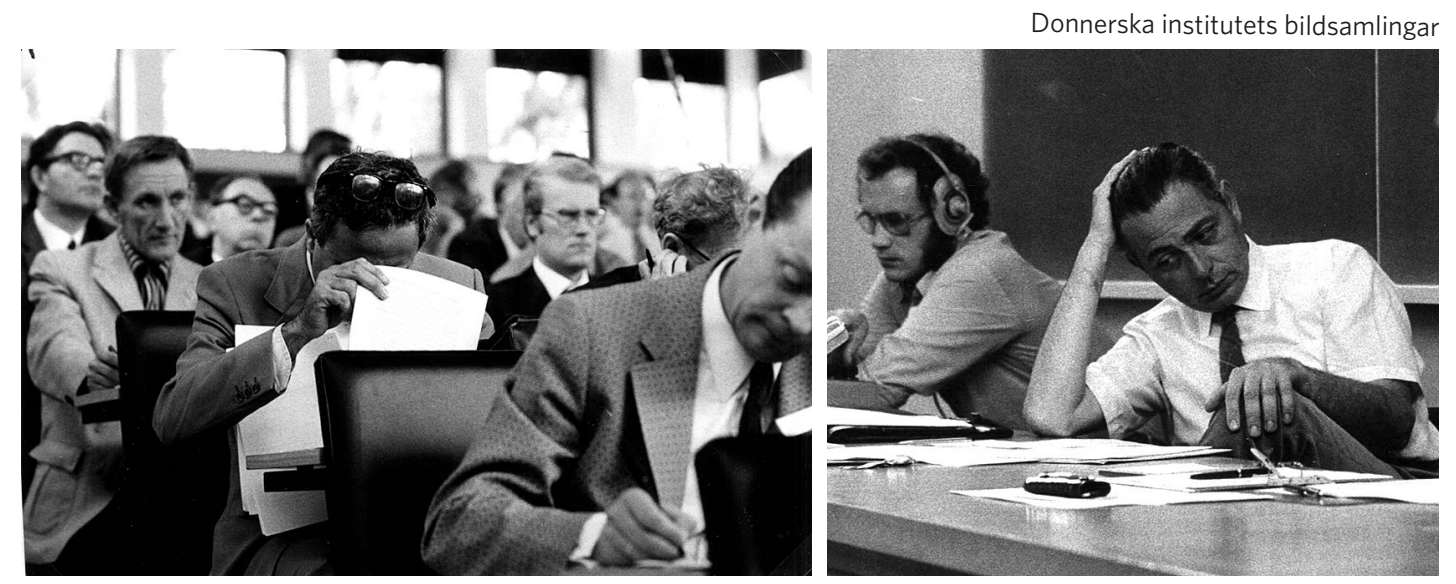

Bilder från IAHR-konferensen i Åbo 1973. Uppe till vänster: Ugo Bianchi läser sina anteckningar, bakom honom Karl-Johan IIIman och Nils G. Holm. Uppe till höger: Lassi Saressalo och Zwi Werblowsky. I mitten: Mircea Eliade på väg ut till Airisto på konferensutfärd. Nere till vänster: Ugo Bianchi och Haralds Biezais. Nere till höger: Lauri Honko i samtal med Carl-Martin Edsman.
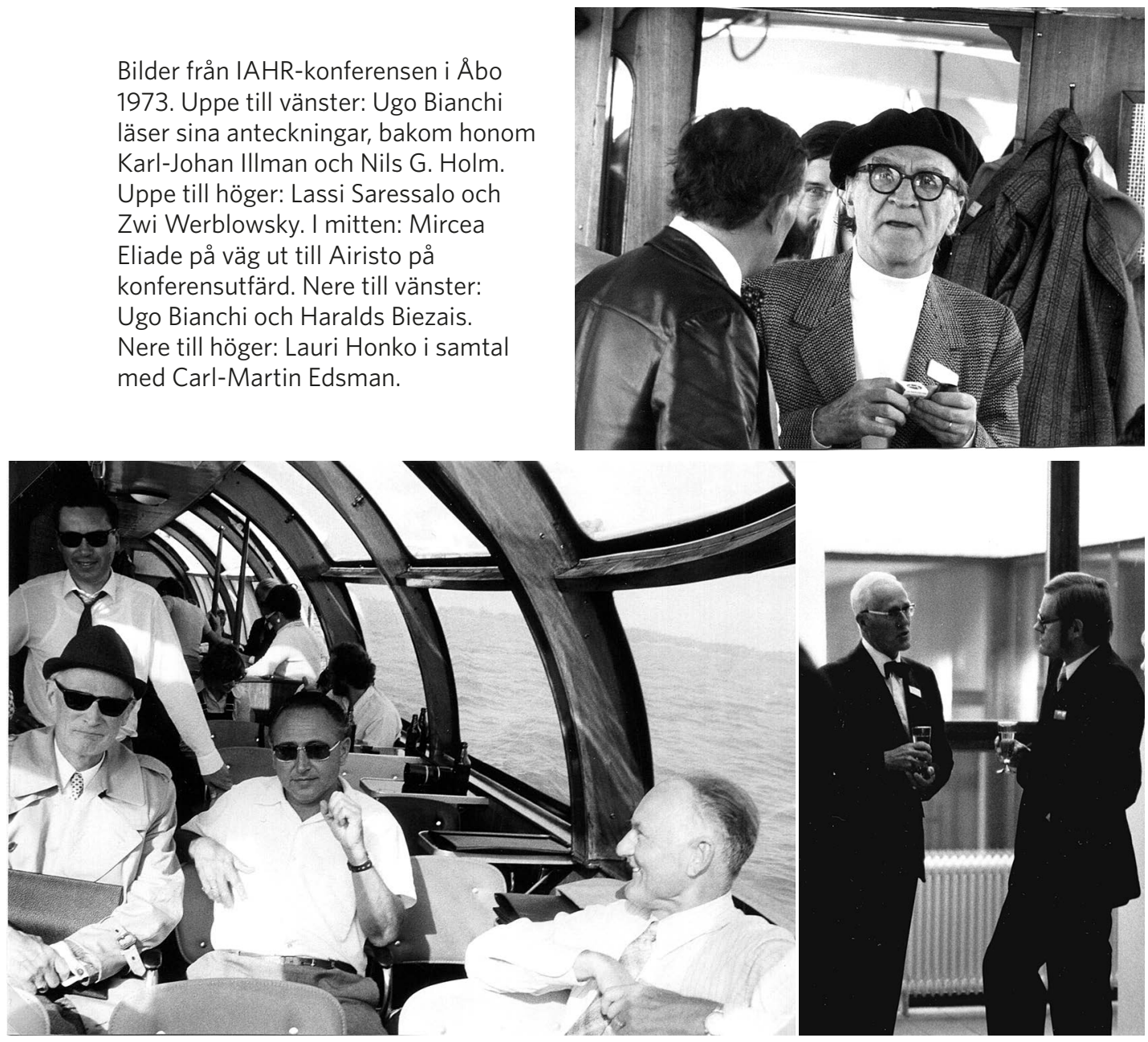


\section{Nils G. Holms och Björn Dahlas privata samlingar}

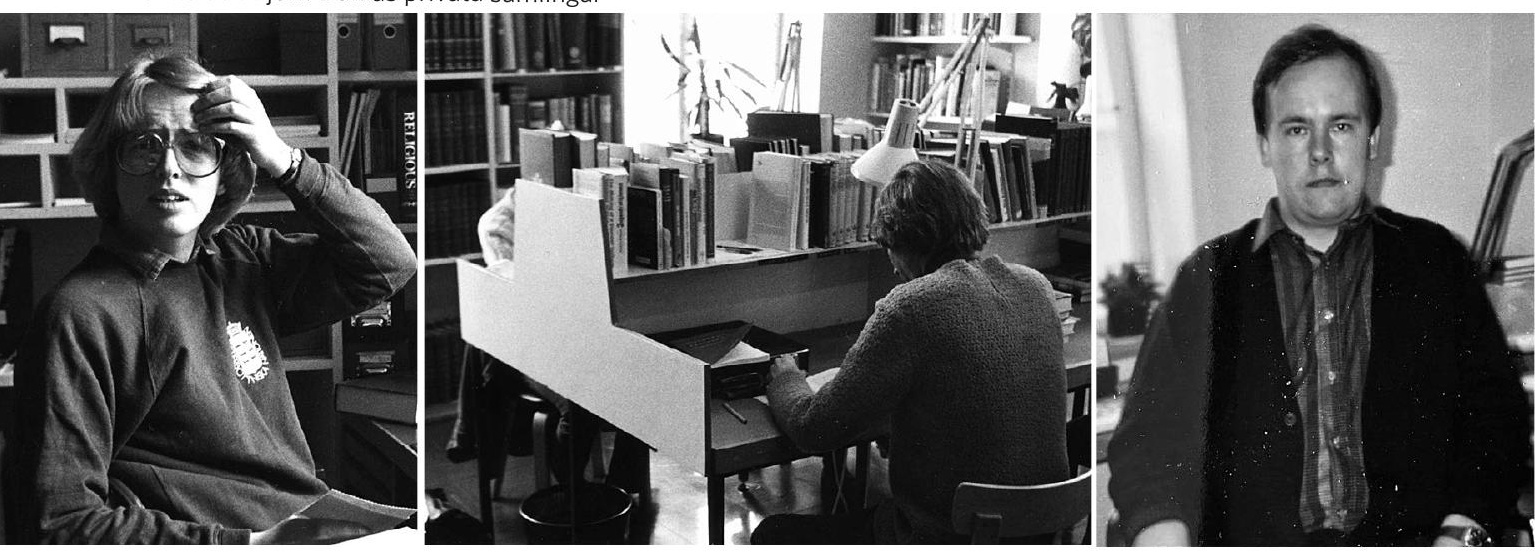

Från vänster: Bibliotekarie Christina Flemming, läsesalen i Donnerska institutet och bibliotekarie Björn Dahla i mitten av 1980-talet.

den finska religionsvetenskapen höll till. Donnerska institutet bidrog även med ett anslag för publiceringen av föredragen jämte diskussioner. Volymen utkom flera år senare.

Professor Biezais var tjänstledig för forskning år 1975 och hade då som ersättare docenten Peter Schalk från Sverige. Även följande år var han ledig någon månad med docenten Jan Hjärpe som tjänsteförrättande professor.

Institutets personal ändrades även i mitten och slutet av I 970-talet. Eftersom de anställda fick ett krav på att de skulle ha studerat religionshistoria blev det så att många av dem som arbetade vid institutet var elever till Biezais. Tore Ahlbäck återanställdes år 1975 som tidigare framgått, Ulrika Wolf-Knuts hade tjänst där, men avgick 30 januari I 976, kortare eller längre pass hade Pertti Järvinen, Elmer Helsing, Susan Sundback, Harriet Lönnqvist, Maud Stolpe och Christina Flemming. Kanslist var Birgitta Eriksson. År 1979 förordnades Björn Dahla som bibliotekarie på halv tid vid institutet.

År 1978 höll man också ett symposium med temat Symbolens religiösa funktion. Professor Biezais avgick från professuren den I juli I 978. 


\section{Ahlbäcks föreståndarskap}

Fil.lic., senare docent Tore Ahlbäck tillförordnades som föreståndare för institutet från den I juli i 978. Det innebar att han var föredragande i styrelsen. Från I 975 var han dessutom sekreterare vid styrelsemötena ända fram till sin pensionering. Under höstterminen 1978 tjänstgjorde Ahlbäck även som tillförordnad professor. Tore Ahlbäck fungerade som föreståndare för institutet fram till den 8 juni 20 I 3. Han var även överbibliotekarie vid akademin åren 1998-2009.

\section{Fler stipendier}

Stipendieutdelningen har under hela institutets tid varit en väsentlig verksamhetsgren. Vi har ovan sett att stipendier i början av verksamheten tillföll personer verksamma inom andra akademiska ämnen ofta med högre akademisk grad. Det fanns ju inte studerande inom ämnet religionshistoria förrän mot slutet av I 960-talet och framför allt under I 970-talet. Många av dem som fick tjänst vid institutet var samtidigt elever i ämnet religionshistoria. Stipendier gavs då och då också åt sökande från andra länder. Dr Tadeuzs Margul från Polen erhöll ett sådant stipendium och uppehöll sig flera månader vid institutet år I 98 I .

I slutet av r 970-talet började en annan generation utbildade ansöka medel. Hit hör Holm som tillsammans med.dr Thorleif Pettersson i Uppsala sökte medel för ett projekt om mystik och intensiva upplevelser.

Holm hade startat ett projekt i psykologi där religions- och psykologilärarna i de svenska gymnasierna skulle förbättra sin kompetens inom just psykologin. Praktiskt taget alla lärare som undervisade psykologi i skolorna deltog i projektet. Forskningsuppgiften var att hos vanliga människor få fatt i upplevelser som gränsade till extas och mystik. År I977 erhöll Holm och Pettersson en ordentlig summa för projektet. 
Holm arbetade intensivt tillsammans med dessa "lärare - elever" $\mathrm{i}$ ett par års tid. Det resulterade för Holms del bl.a. i boken Mystik och intensiva upplevelser 1979. Följande symposium ägde rum den 26-28 augusti I98 I med temat religiös extas. Resultaten från projektet presenterades bl.a. vid det symposiet. Bidragen trycktes i Scripta nr I I. Holm hade utsetts till redaktör för Scripta som innehöll bidragen vid symposiet.

\section{Konferenser och kollokvier}

De yngre forskarna ville starta egna vetenskapliga konferenser. En större sådan anordnades i Mariehamn hösten 1975 med bidrag från hela Norden. Hösten 1978 tog Ahlbäck och Holm initiativ till att hålla forskarkollokvier i Tvärminne biologiska station halvvägs ner till Hangö. Kontakt togs med professor Lauri Honko som var ordförande för Religionsvetenskapliga sällskapet i Finland och han var

Tore Ahlbäck är född $1941 \mathrm{i}$

Helsingfors. Vid Åbo Akademi studerade han teologi och religionsvetenskap. Teologie kandidatexamen erhöll han 1969 och för filosofie doktorsgrad disputerade han år 1983 på en avhandling benämnd Människosonen - en självgjord messias i Tyskland efter första världskriget. I övrigt har han i sina publikationer koncentrerat sig på teosofi och antroposofi.

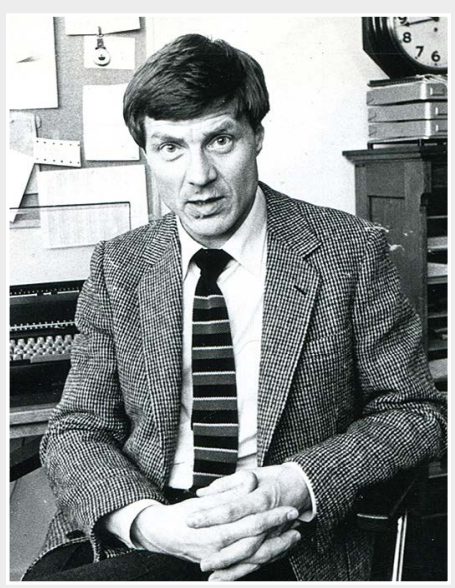
Ämbetsexamen för vetenskapliga bibliotek erhöll han 1972. Docentur i religionsvetenskap vid Åbo Akademi fick han 1996. Han tjänstgjorde som bibliotekarie vid Donnerska institutet och som föreståndare från sommaren 1978. Som överbibliotekarie vid Åbo Akademi fungerade han åren 1998-2009. Han var ordförande för Religionsvetenskapliga sällskapet i slutet av 1990-talet. Då hade han ansvar för utgivningen av tidskriften Temenos. Han pensionerades år 2013. (Bild: Kyrkpressen) 
med på noterna från början. Den första sammankomsten hölls den 8-9 oktober 1978 i Tvärminne. Temat denna gång var fältforskningen och dess problem. Honko höll ett anförande tillika med Kirsti Suolinna, Kaisa Sinikara, Martti Junnonaho, Päivikki Suojanen, René Gothóni och Holm. En fyllig redogörelse för kollokviet gavs av Susan Sundback i Temenos vol. I4, 1978.

Praktiskt taget varje år hölls sådana seminarier. Temana var ofta de aktuella händelserna just då så symposierna kunde benämnas t.ex. Nya religiösa rörelser, Islam idag, Kvinnor och reli-

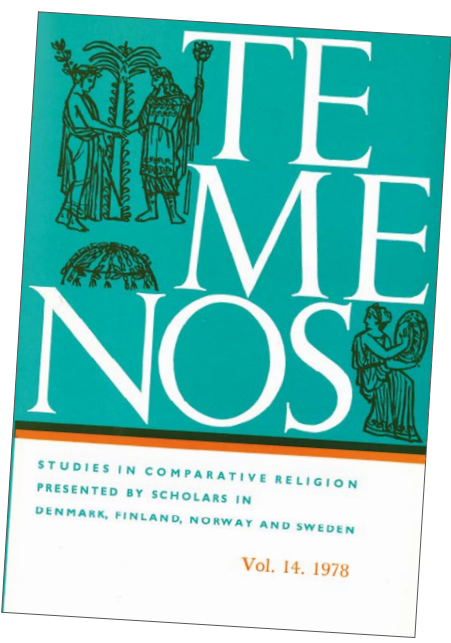
gion, Religions- och kulturekologi, Finlands gamla religion.

Donnerska institutet har regelbundet bidragit med ekonomiskt stöd till dessa för religionsforskningen i Finland betydelsefulla seminarier. Tvärminneseminarierna har varit ett forum där forskarstuderande vid de olika religionsvetenskapliga institutionerna i Finland kunnat mötas och diskutera. Första tiden talade man finska och svenska. Alla förstod varandra. $\mathrm{Nu}$ har man sedan flera år tillbaka övergått till enbart engelska.

Föreståndaren Ahlbäck engagerade sig denna tid bl.a. i Religionsvetenskapliga sällskapet, bl.a. som dess ordförande. Sekreterare hade han varit en längre tid. Till uppgifterna hörde att administrera tidskriften Temenos och få den till trycket. Han verkade dessutom ofta inom informationsvetenskapen och bidrog till utvecklandet av det ämnet vid akademin.

\section{Professuren lösgörs från institutet}

Från början av 1979 förordnades Holm till professor. Holm hade disputerat för teologie doktorsgraden i Uppsala r 976 med en avhandling om tungomålstalande bland finlandssvenska pingstvänner. Denna tid pågick förhandlingar om att staten helt skulle överta Åbo Akademi. I det sammanhanget ville man också att professuren i religionshistoria 


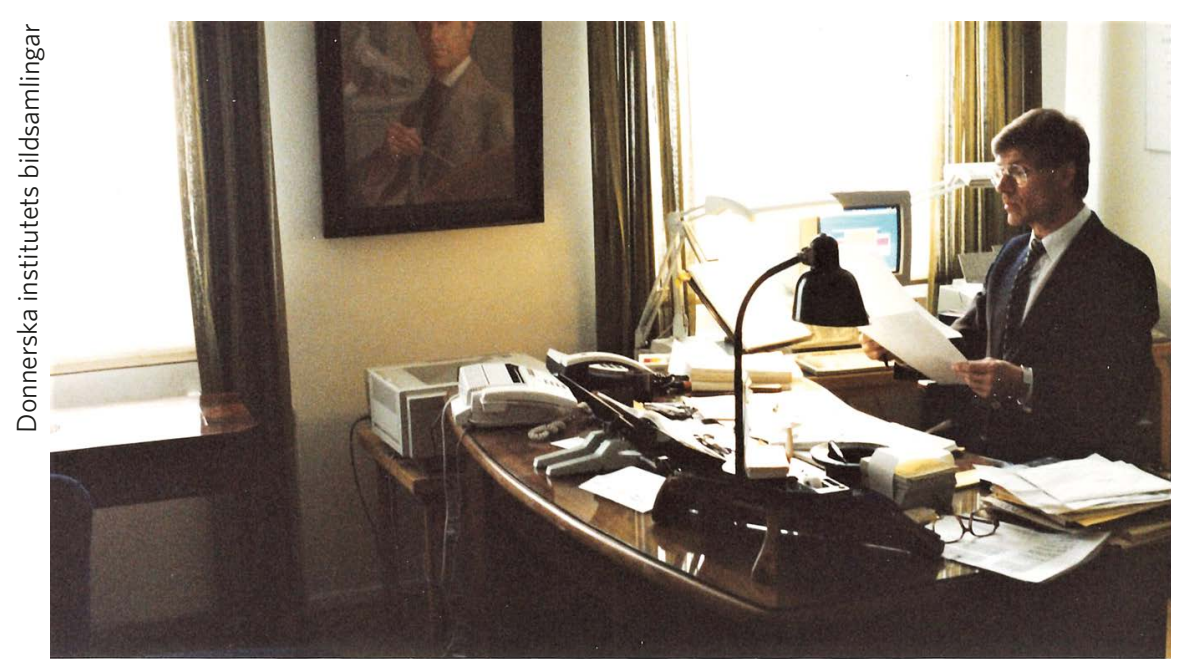

Tore Ahlbäck i sitt arbetsrum på Gezeliusgatan 2.

skulle övergå till humanistiska fakulteten och akademin helt och hållet. Därför skedde en utlysning av professuren i 978. Flera sökande anmälde sig, bland dem Jan Hjärpe, Anders Hultgård och Holm. En respittid för komplettering av meriter gavs och sakkunnigförfarande sattes igång. De tre nämnda sökandena fick alla lika många röster baserat på sakkunnigas utlåtanden varför fakulteten beslöt att utse Holm till ordinarie professor. Detta skedde från I juli i $98 \mathrm{I}$.

Våren I 98 I var Holm forskarledig med anslag från Finlands Akademi. Carl-Martin Edsman tjänstgjorde som professor. Förstatligandet av akademin skedde den I augusti I 98 I. Det var nu alltså första gången professuren tillsattes med normal ansökningsprocedur. Professuren blev med andra ord helt frikopplad från Donnerska institutet. Fysiskt tjänstgjorde professorn ändå i samma lokaliteter som institutet. Tore Ahlbäck utsågs till ordinarie föreståndare från den I 3 september I 982. Ahlbäck disputerade som den förste i ämnet religionshistoria år 1983 , och hans avhandling bär titeln Människosonen - en självgjord messias $i$ Tyskland efter första världskriget. I övrigt är Ahlbäck specialiserad på teosofi och antroposofi. Han har även kompetens inom informationsvetenskap.

Det kan nämnas att då professor Holm avgick från professuren i religionsvetenskap sommaren 2008 efterträddes han av Peter Nynäs. 


\section{H. W. Donners frånfälle}

Nyårshelgen I98 I avled H. W. Donner i sitt hem i Oxford. $\mathrm{Nu}$ blev det nyordning i styrelseuppdragen vid institutet. Donner hade varit ordförande för styrelsen ända från första början. Carl-Martin Edsman blev ordinarie ledamot från Uppsalafakulteten och ordförande för styrelsen, och Helmer Ringgren blev hans ställföreträdare. Från Åbo satt Patrick Bruun med och som hans ersättare Nils Storå. Ytterligare var överbibliotekarien Olof Mustelin och professor Lars Erik Taxell med.
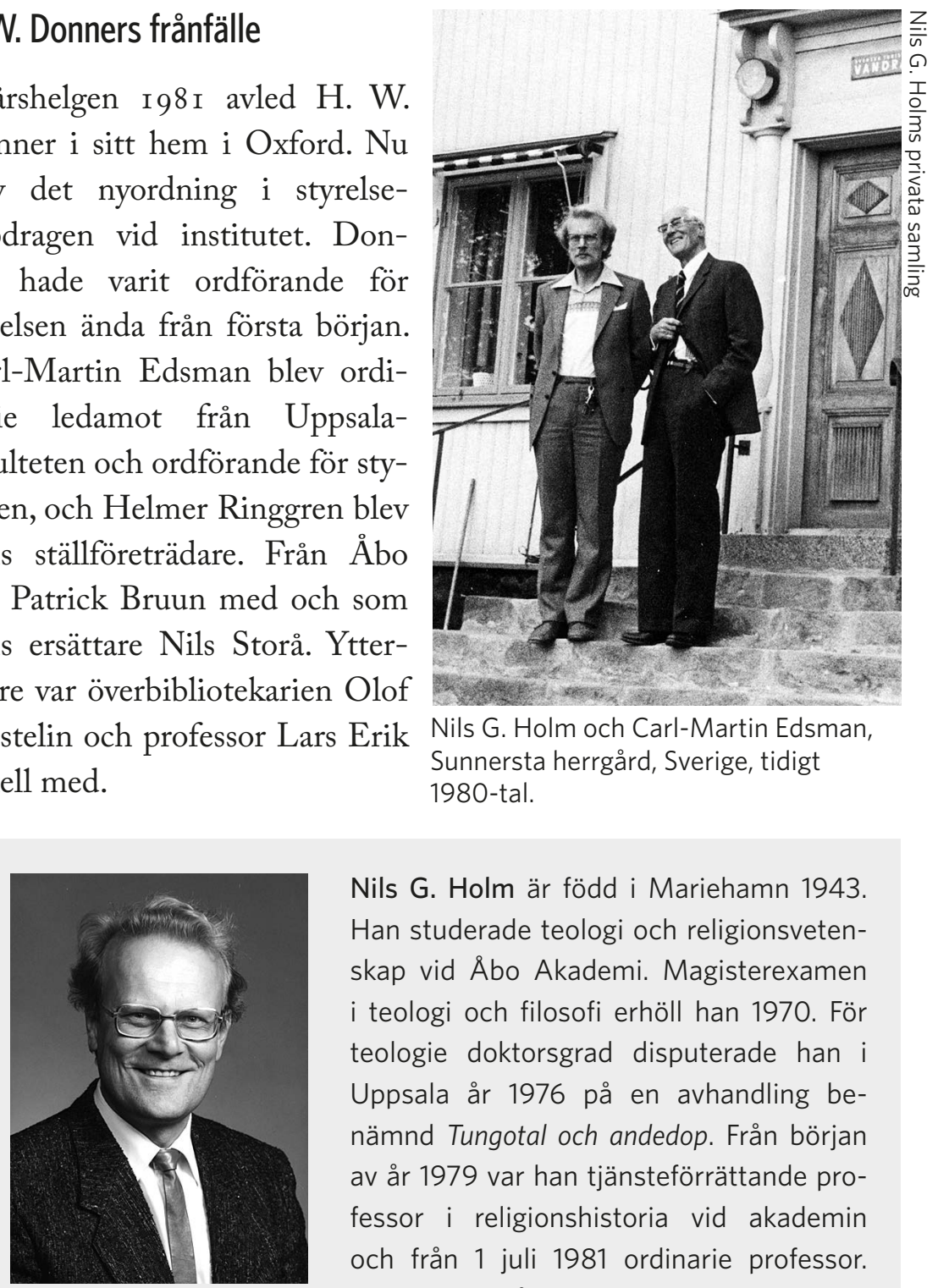

Nils G. Holm är född i Mariehamn 1943. Han studerade teologi och religionsvetenskap vid Åbo Akademi. Magisterexamen i teologi och filosofi erhöll han 1970. För teologie doktorsgrad disputerade han i Uppsala år 1976 på en avhandling benämnd Tungotal och andedop. Från början av år 1979 var han tjänsteförrättande professor i religionshistoria vid akademin och från 1 juli 1981 ordinarie professor. Han avgick från professuren 2008. Under sin professorstid utgav och ansvarade han för skriftserien Religionsvetenskapliga skrifter. I den serien har han publicerat ett par läroböcker som lästs flitigt. Det är Religionspsykologins grunder och Religionshistoria. En introduktion med textläsning. I Donnerska institutets styrelse satt han åren 1983-2016. (Bild: Nils G. Holms privata samling) 


\section{Nya stadgar och nytt reglemente}

I och med att professuren lösgjordes från Donnerska institutet gjorde man om stadgarna något. Representanterna för humanistiska fakulteten skulle inneha professorskompetens och stipendierna skulle helt avgöras av Donnerska styrelsen. Ledamöterna tillsattes för tre år åt gången. Ett reglemente fastslogs också. I reglementet fastställs föreståndarens uppgifter, till vilka hör att leda verksamheten och att bedriva forskning är önskvärt. Biblioteket bör enligt reglementet vara ett presensbibliotek.

Personalen bevistade olika konferenser, både sådana som handlade om religion och sådana som befordrade biblioteksvetenskapen. Man utgav två hjälpmedel för att komma åt tidskrifter och nyanskaffningar: Contenta religionum och Biblioteksnytt.

Anskaffningen av böcker fortsatte i de banor som var utstakade. Biblioteket var vid den här tiden ett av de större religionsvetenskapliga biblioteken i Norden. Man försökte täcka de flesta stora religioner men även mindre rörelser. Protestantisk kristen religion satsade biblioteket inte på eftersom akademin har en teologisk fakultet med eget fakultetsbibliotek. Biblioteket var främst ett presensbibliotek. Så småningom

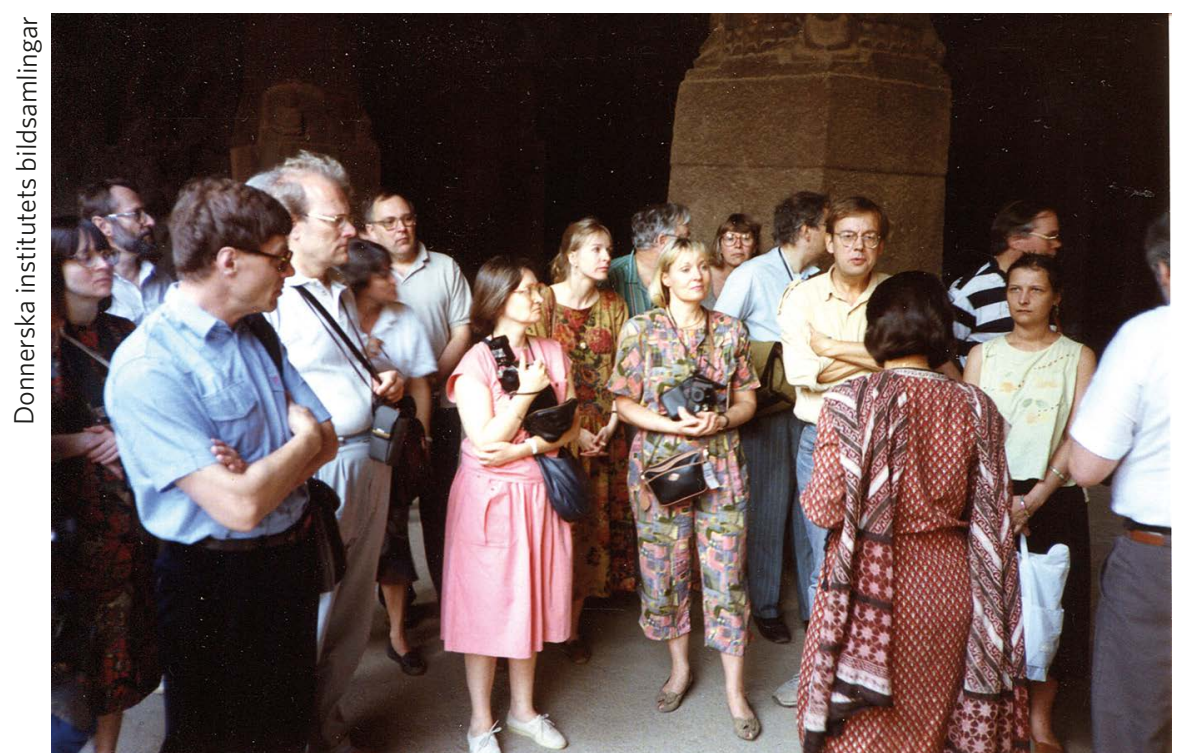

Studieresa till Indien, år 1993. Till vänster Tore Ahlbäck och Nils G. Holm. 
började man dock låna ut böcker alltmer, och därmed utökades användningen av böckerna.

\section{Fortsatt konferensverksamhet}

Konferenser hölls, bl.a. ett par om samisk religion, om religiösa riter, om dans, musik och konst, om metodologi och ritualistik. Symposierna var det främsta medlet att nå ut till en större krets. Man övergick också ganska snabbt till att enbart använda engelska under konferenserna.

En s.k. resekonferens hölls i januari i 99ı. Flera av lärarna i religion på akademisk nivå i Norden samlades för att resa till Indien. Man besökte framför allt södra delarna av Indien, och höll föreläsningar om olika teman i anslutning till det man sett och upplevt i Indien. Här var professorerna Peter Schalk, Jan Bergman och Tord Olsson aktiva. Ledare för resan var Rolf Grönblom från Helsingfors. Han hade gjort många resor till Indien och kunde sägas vara något av specialist trots att han inte studerat religion på akademisk nivå.

En större konferens hölls den 4-7 augusti 1997 med rubriken "Methodology in the Study of Religions". Den var tillika en s.k. regional konferens för IAHR (International Association for the History of Religions). Konferensbidragen trycktes i Scripta nr I 7 nr I-2 med titeln Approaching Religion. Konferensen var på sätt och vis en fortsättning på den stora metodkonferensen som anordnades I973. Konferensen hölls på Kristliga institutet i Åbo. Denna tid hölls de flesta konferenser på Kristliga institutet som har goda inkvarteringsmöjligheter, goda utrymmen för föredrag och samlingar samt en god restaurang. Det blev allt vanligare att musikevenemang framfördes i början och ibland också på slutet av konferenserna. På senare år har konferenserna återgått till akademins utrymmen i ASA-huset. 


\section{Utställningar och stipendier}

Vid institutet anordnades på r 990-talet ett flertal utställningar i institutets lokaler. Här kan bl.a. nämnas en om scientologi, en om Nepal och en om Edith Södergran och Steiner. Stipendier för forskare från länder längre bort kunde ibland beviljas. Sålunda tillkom stipendium för Tadeusz Doktór, Polen, och A. Veluppillai, Indien.

\section{Ekonomisk depression}

I början av I 990-talet nåddes institutet av den allmänna depressionen. De tillbudsstående medlen ville inte räcka till ens för tjänsterna vid institutet. Det var mycket nära att behöva säga upp en anställd. Tack och lov blev det inte så. Genom att Birgitta Eriksson-Katajainen, som varit kanslist sedan 1974, avgick på egen begäran 1996, kunde bibliotekarietjänsterna kvarstå. Stipendierna måste helt och hållet dras in år I 993. Först långt senare kunde stipendier igen börja delas ut men utan ansökningsprocedur och endast på förslag av styrelsen.

I dag är dock situationen för stipendier en helt annan. Det återkommer vi till längre fram.

\section{Ämnet religionshistoria flyttar}

Det kan nämnas att i augusti I 99 I flyttade ämnet religionshistoria till nyrenoverade lokaler i Domus, Biskopsgatan ı. Där samexisterade man med folkloristiken i drygt tio år. Då de nya utrymmena i Arken på Fabriksgatan 2 blivit färdiga flyttade man dit år 2003.

Det kan också nämnas att ämnet religionshistoria ändrades till religionsvetenskap efter att styrelsen för Donnerska institutet hörts år I 994. Religionsvetenskap som benämning var bättre med tanke på att ämnet på finska heter"uskontotiede" och för att ämnet inte bara är historiskt utan mycket också inriktat på psykologi och sociologi.

Förhandlingar om att ämnet religionsvetenskap skulle övergå till teologiska fakulteten fördes på i 990-talet. Med tanke på ekonomin och studenttillströmningen skulle det ha kunnat vara motiverat. Donnerska 


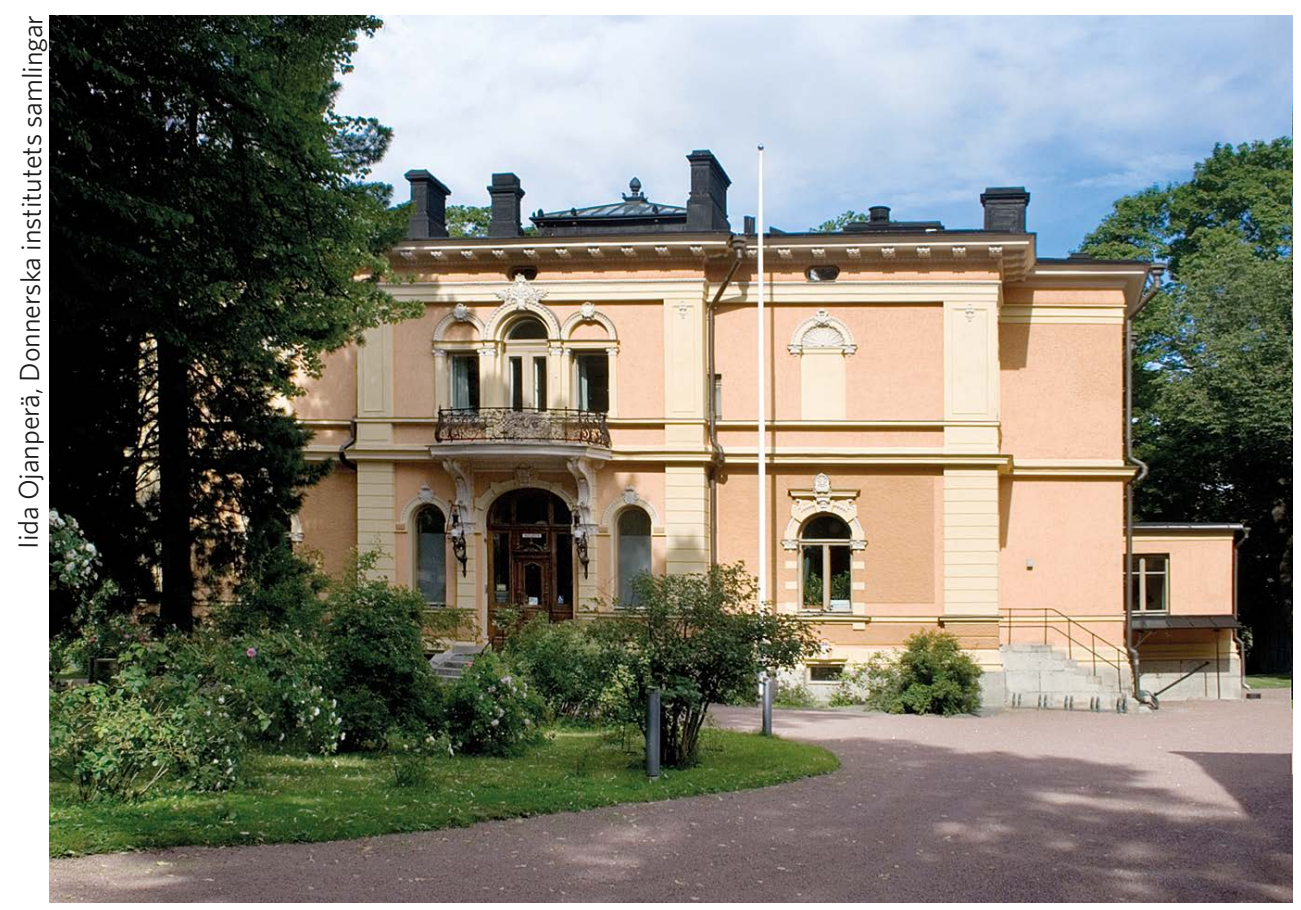

Humanisticum, Biskopsgatan 13 i Åbo inrymmer Donnerska institutet sedan 2005.

institutets styrelse avslog dock initiativet. Donatorernas vilja var ju att ämnet uttryckligen skulle finnas vid humanistiska fakulteten. Idag är läget annat då fakultetsgränserna upplösts.

\section{Donnerska flyttar till Humanisticum}

En större förändring skedde år 2005 för institutet. Då lämnade man det s.k. Tryckerihuset och flyttade in i det då alldeles nyrenoverade Humanisticum vid Biskopsgatan I 3. Huset är ett förnämt patricierhus som en gång tillhört familjen Ernst och Rosina Dahlström. 


\section{IIImans föreståndarskap}

\section{Anställda och bibliotekets utveckling}

Från mitten av juni 2013 har docent Ruth Illman handhaft föreståndarskapet. Hon var först anställd som forskare vid institutet något år men fick tjänsten som föreståndare då Ahlbäck avgick. Hon hade disputerat första gången $\mathrm{i}$ ämnet religionsvetenskap vid Åbo Akademi år 2004 med en avhandling om interkulturell kommunikation. Senare initierade hon ett projekt om den mystiska hasidiska sångtraditionen niggunim. Hon lade fram sin andra doktorsavhandling Music and Religious Change among Progressive Jews in London: Being Liberal and Doing Tradition (Lexington Publications) för disputation i ämnet judaistik vid Åbo Akademi den 30 november 2018.

Som föreståndare har Illman ansvaret för att planera och leda institutets och bibliotekets verksamhet mot de uppsatta målen. Vidare gäller det för henne att följa upp budgeten och bereda konferenser och

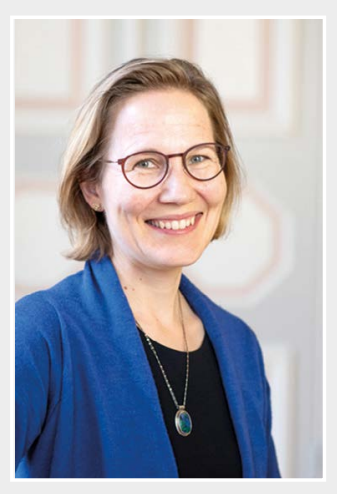

Ruth Illman är född 1976 i Åbo. Hon studerade religionsvetenskap och disputerade år 2004 i det ämnet med en avhandling om kulturmöten. Efter det har hon koncentrerat sig på judendom, särskilt modern sådan. Hon disputerade andra gången vid akademin inom ämnet judaistik med en avhandling om den judiska sångtraditionen niggunim. Hon har en mängd förtroendeuppdrag bl.a. vid Vetenskapsrådet i Stockholm och vid Svenska litteratursällskapet i Finland. Hon är docent både vid Åbo Akademi och vid Uppsala universitet. Sedan 2013 är hon föreståndare för Donnerska institutet. (Foto: Satu Karmavalo) 
symposier, samt att se till att institutets publikationer ges ut. Också forskning upp till 50\% kan ingå.

Då den nya föreståndaren började utgjordes personalen vid institutet av filosofie magistern Björn Dahla, mångårig bibliotekarie, filosofie magistern Anna Nyman och filosofie magistern Joakim Alander. Tidvis var även filosofie magistern Victoria Nystrand anställd.

Dahla har under sin tid vid institutet huvudsakligen haft hand om bokval och litteraturbeställningar, indexering, klassificering, handledning av kunder i informationssökning. Han har dessutom varit arbetarskyddsansvarig samt fungerat som symposiesekreterare, ett uppdrag han tyckt om. Han har även ansvarat för digitalisering av institutets arkiv. Med åren har uppgiften blivit mer grannlaga med tanke på den stora volymen böcker som ges ut och att temana kan variera kraftigt. Dahla avgår med pension våren $202 \mathrm{I}$ efter mer än fyrtio år vid institutet.

Alander har haft hand om katalogisering av nyinköpta böcker och bokserier samt skött om retroaktiv katalogisering. Han har även ansvarat för arbetet att ta i bruk det nya bibliotekssystemet Alma Ex Libris. Utlåning och kundservice har också fallit på honom.

Vid sidan av Ruth Illman, Björn Dahla och Joakim Alander anställdes filosofie magister Malin Fredriksson år 2016. Malin Fredriksson har burit ansvar för att utveckla arbetet kring öppen vetenskap (open access) inom institutet och har dessutom deltagit i

Donnerska institutets personal år 2018, från vänster: Joakim Alander, Björn Dahla, Malin Fredriksson och Ruth IIIman.

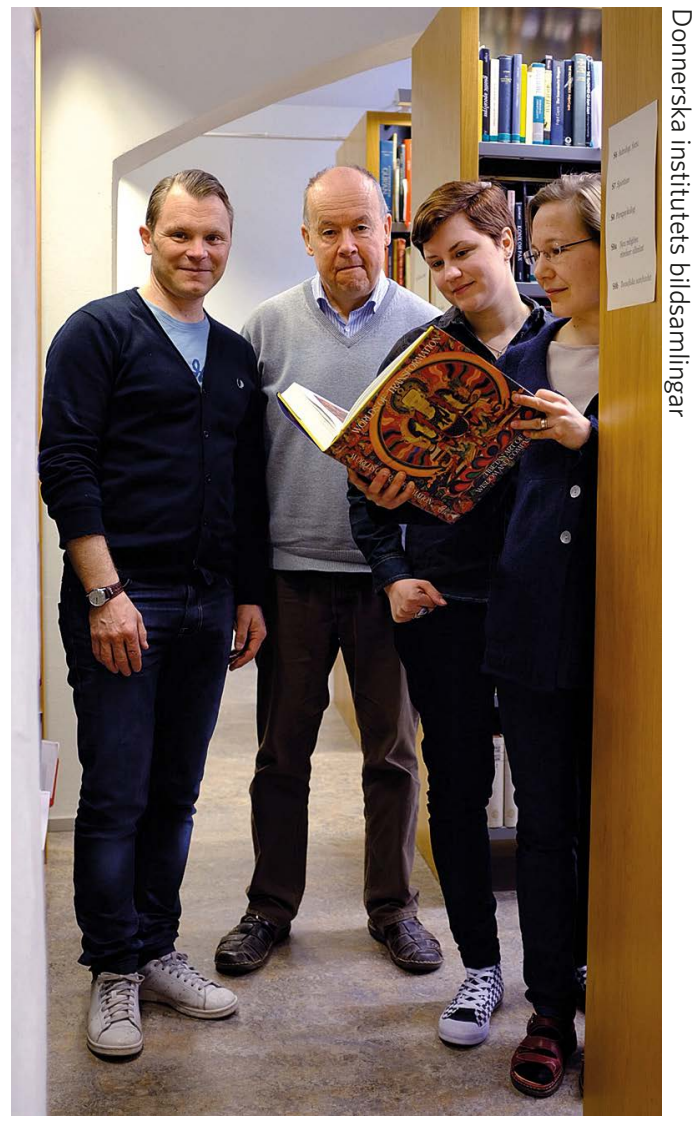


indexerings- och katalogiseringsarbetet. Hon har även kunnat bedriva egen forskning.

Hösten 2020 beslöt man i styrelsen att även anställa en forskarbibliotekarie från den I januari $202 \mathrm{I}$. Efter en ansökningsprocess med många sökande föll valet på docenten i religionsvetenskap Sofia Sjö. Hennes uppgift blir uttryckligen forskning vid sidan av biblioteksarbete.

Biblioteket, som verkat över sex decennier, har nu en samling på ca 90000 volymer. Antalet tidskrifter och serier uppgår till ca 600. Man hittar institutets skrifter i bibliotekskatalogen Alma och i den nationella bibliotekskatalogen Linda. Institutet arbetar alltmer digitalt, och tidskrifter och annat material når man närmast i elektronisk form. Besöksfrekvensen håller man inte längre så noga reda på. De flesta når institutet via internet.

År 2019 påbörjades arbetet med att förbereda en ny strategi för åren 2020-2022. Vi återkommer till den senare. Det är en mängd aktiviteter som institutet ägnat sig åt under senare år. Här kan inte bli fråga om att räkna upp alla sådana, men något kan ändå redogöras för.

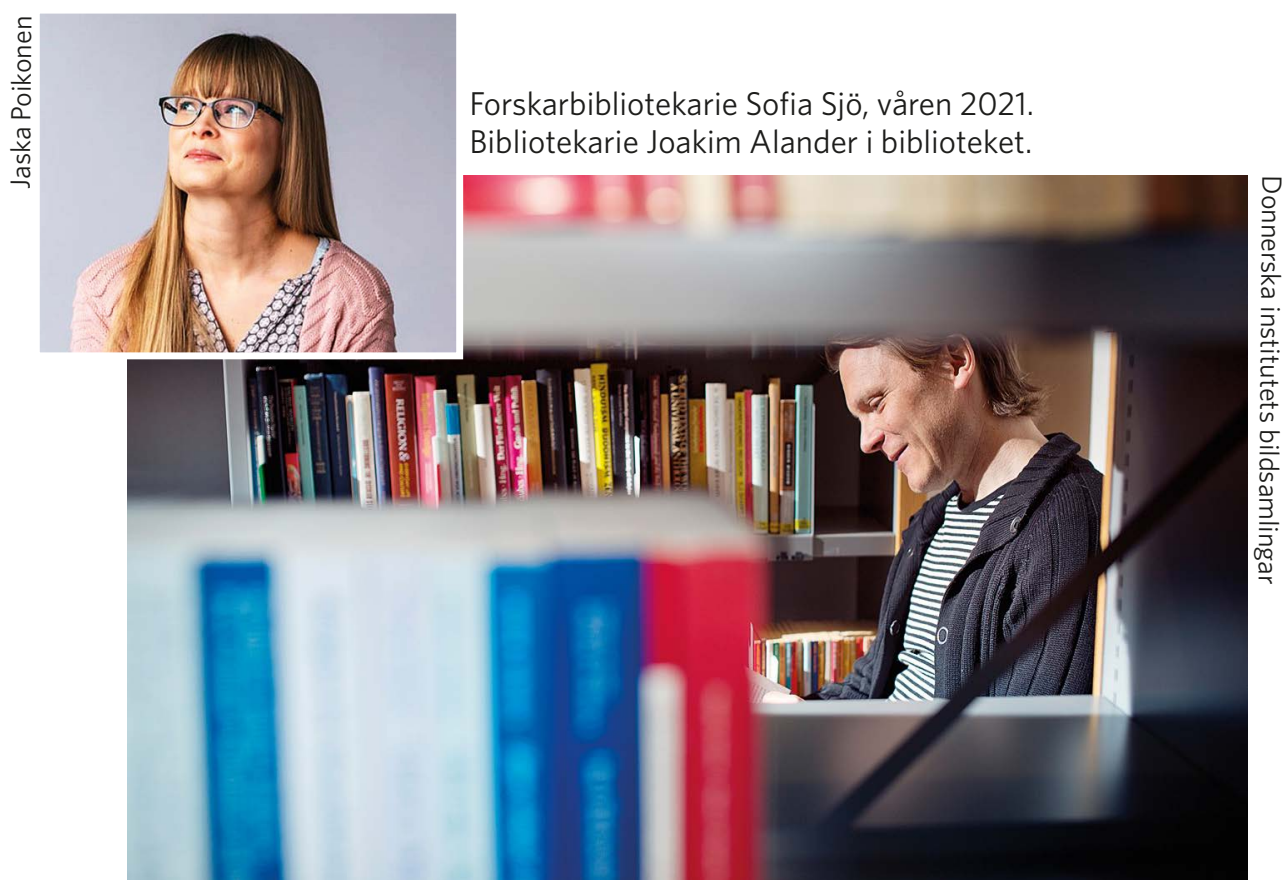




\section{Stipendier och pris}

Stipendierna har ända sedan begynnelsen varit en viktig verksamhetsform. Ibland har medlen sinat och då har stipendierna dragits in. $\mathrm{Nu}$ är situationen dock gynnsam för utdelning. Stipendierna för forskarstuderande kan uppgå till ettårsstipendium eller flera halvårsstipendier. Tyngdpunkter i stipendierna är Åbo och Uppsala. Sedan ett par år tillbaka utlyser man igen stipendierna att sökas. Ett tjugotal ansökningar brukar strömma in.

På initiativ av styrelsen och dess ledamot Mattias Gardell började man 20 I o årligen dela ut ett pris för framstående religionsforskning vid ett nordiskt universitet. Nordiska institutioner kan sända in förslag till prismottagare. Religionsvetenskap uppfattas i mycket vid bemärkelse, men forskningen bör vara relativt ny, vilket betyder att högst fem år gammal forskning kommer ifråga. Prissumman är 5000 euro. Hittills har man delat ut tio sådana prisbelöningar. Den första mottagaren var Ferdinando Sardella, Göteborgs universitet. Han skrev om indiern Bhaktisiddhanta Sarasvati.

Den I 3 december 2013 firades Religionsvetenskapliga sällskapets 50-årsjubleum. Holm hade skrivit 5o-årshistoriken. Vid det tillfället delades Donnerska institutets pris för framstående religionsforskning ut. Det tillföll filosofie doktor Jessica Moberg från Södertörns högskola. Hennes avhandling behandlar den karismatiska fromheten i en församling i Stockholmsområdet.

År 2017 tillföll priset docent Måns Broo vid Åbo Akademi för boken The Radha Tantra: A Critical Edition and Annotated Translation (Routledge 20I7). Ännu kan nämnas att 2019-års pris tillföll teol.dr Oriol Poveda Guillén för boken According to Whose Will: The Entanglements of Gender E Religion in the Lives of Transgender Jews with an Orthodox Background (Uppsala universitet 20I 7 ). 


\section{Symposier, rundabordskonferenser, Aboagora}

Symposierna som pågått sedan I 962 fortsätter vartannat år. Sammanlagt har 27 symposier hållits. Publiceringen sker som tidigare i Scripta som började utges i digitalform år 20I4. Denna skriftserie som alltså går tillbaka på den första konferensen 1962 vid institutet kan sägas vara paradformen för den vetenskapliga verksamheten. Den är referensbaserad för att kvaliteten ska nå högsta akademiska nivå, och den vänder sig till en bred internationell forskarkrets. Den överfördes 2016 till publiceringsplattformen journal.fi.

Rundabordskonferenser har hållits sedan 20IO. År 2012 var temat "The New Visibility of Atheism in Europe". Dessa konferensers bidrag ges ut i e-journalen Approaching Religion, som utkommer två gånger om året. Både Scripta och Approaching Religion är öppet tillgängliga (open access).

Återkommande stöd ges årligen Religionsvetenskapliga sällskapet i Finland som grundades 1963 på initiativ av Lauri Honko och Helmer Ringgren. Seminariet Aboagora som initierades i samband med Åbos kulturhuvudstadsår 20 I får stöd. Det har utvecklats på ett förträffligt sätt och ger institutet idag bred synlighet. Samarbete med

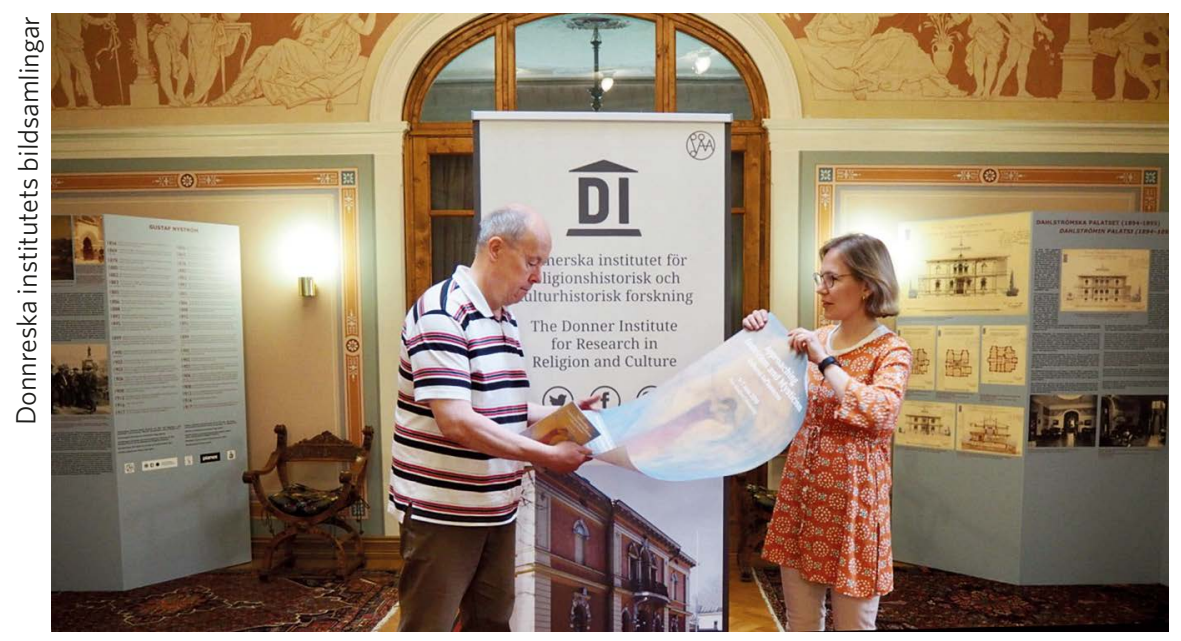

Bibliotekarien Björn Dahla och föreståndaren Ruth IIIman förbereder konferensen "Esotericism and Mysticism: Cultural Influences" i Humanisticum sommaren 2019. 

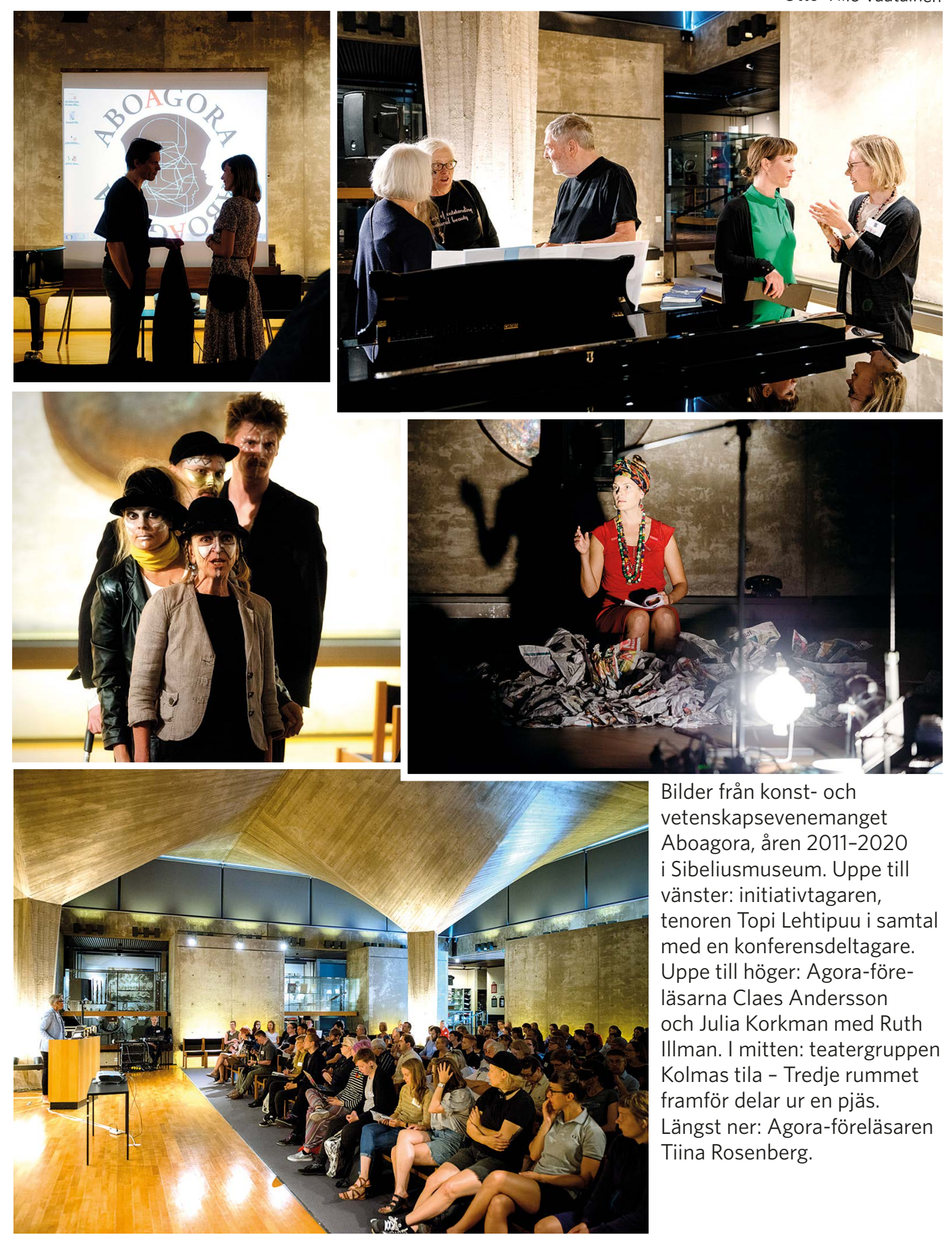

Bilder från konst- och vetenskapsevenemanget Aboagora, åren 2011-2020 i Sibeliusmuseum. Uppe till vänster: initiativtagaren, tenoren Topi Lehtipuu i samtal med en konferensdeltagare. Uppe till höger: Agora-föreläsarna Claes Andersson och Julia Korkman med Ruth IIIman. I mitten: teatergruppen Kolmas tila - Tredje rummet framför delar ur en pjäs. Längst ner: Agora-föreläsaren Tiina Rosenberg. 
olika institutioner inom konstvetenskap och utövande konstnärskap sker kontinuerligt.

År 2013 ordnades Aboagora med titeln"The Human Machine". Vidare ordnade institutet det traditionella Tvärminne-seminariet för doktorander samt deltog i utgivningen av Temenos. Nummer 25 av Scripta utkom med titeln Digital Religion. Man började även med planeringen av en digital plattform för Temenos. Institutets egen e-publikation utkom med två nummer: "Shifting Gear: New Agendas in the Sociological Study of Religion" och "Aboagora: The Human Machine”.

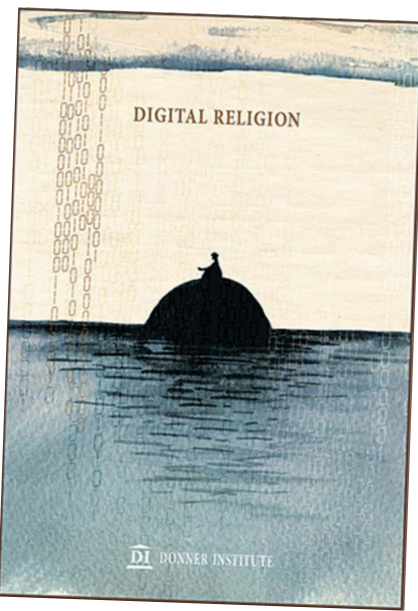

Två stora internationella och interdisciplinära konferenser anordnades i Åbo 20I3. Den ena var den 32 konferensen för International Society for Sociology of Religion (ISSR) och den andra "The Role of Theory in Folkloristics and Comparative Religion" för att hedra minnet av professor Lauri Honko ( I 932-2002) som verkat vid finska universitetet i Åbo. Som nummer fyra i e-publikationen Approaching Religion utkom år 20I4 även "The Legacy of Lauri Honko, Contemporary Conversations" med Pekka Hakamies och Ulrika Wolf-Knuts som gästredaktörer.

Det kan vidare nämnas att lektor Janne Tunturi initierade ett projekt kring den historiskt intressanta kartboken Mercator som finns utställd i biblioteket. I e-publikationen $A p^{-}$ proaching Religion utkom 2016 "Tracing Circulations: The Case of the MercatorHondius Atlas r6 r3".

Mercator-Hondius atlas från år 1613 finns utställd i Donnerska institutets bibliotek. Foto: Björn Dahla.

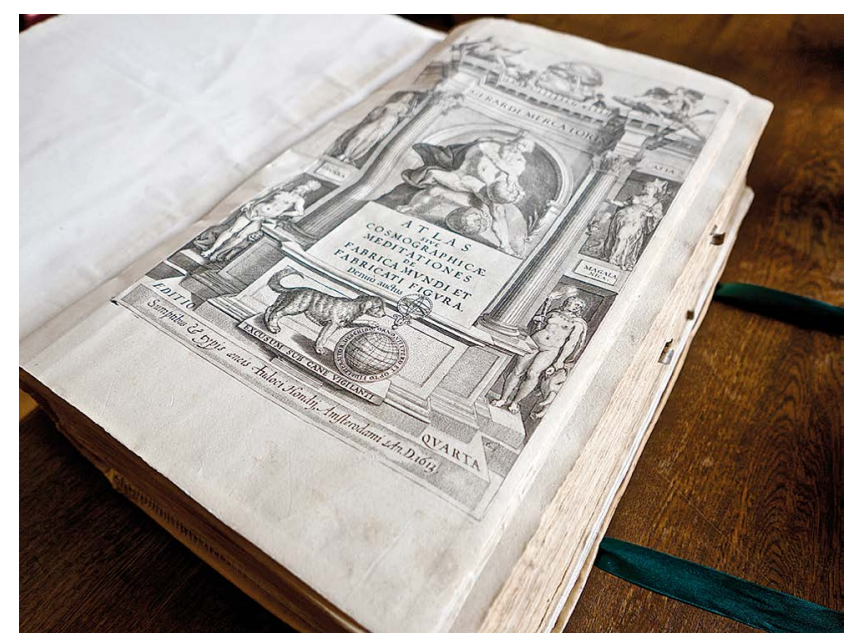


Donnerska institutets bildsamlingar
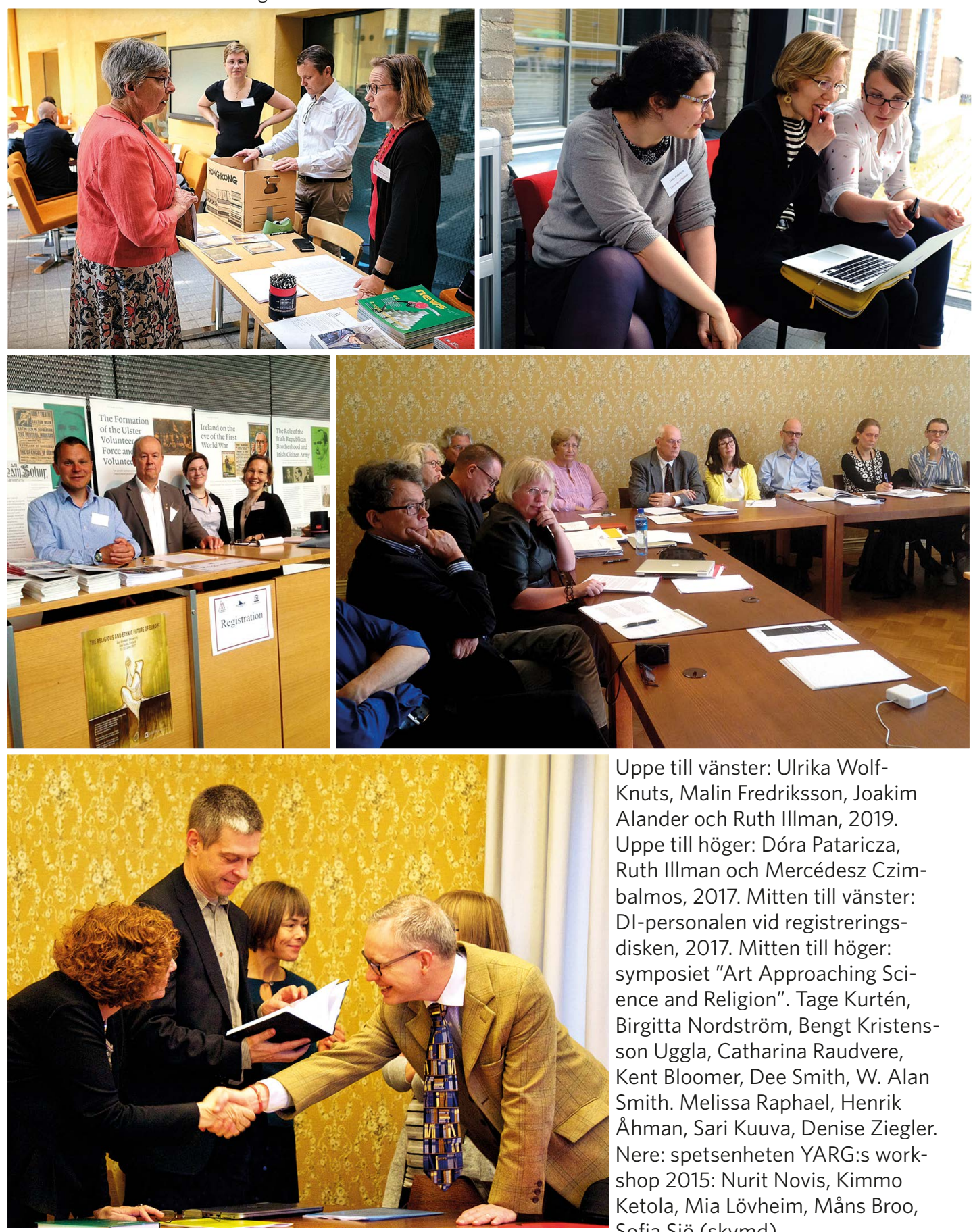

Uppe till vänster: Ulrika WolfKnuts, Malin Fredriksson, Joakim Alander och Ruth IIIman, 2019. Uppe till höger: Dóra Pataricza, Ruth IIIman och Mercédesz Czimbalmos, 2017. Mitten till vänster: DI-personalen vid registreringsdisken, 2017. Mitten till höger: symposiet "Art Approaching Science and Religion". Tage Kurtén, Birgitta Nordström, Bengt Kristensson Uggla, Catharina Raudvere, Kent Bloomer, Dee Smith, W. Alan Smith. Melissa Raphael, Henrik Åhman, Sari Kuuva, Denise Ziegler. Nere: spetsenheten YARG:s workshop 2015: Nurit Novis, Kimmo Ketola, Mia Lövheim, Måns Broo, Sofia Sjö (skymd). 
E-publikationen Approaching Religion utkom år 2015 med två nummer: "Pentecostalism around the Baltic Sea" med gästredaktör Tuija Hovi och "Systems Thinking, Spirituality and Wisdom: Perspectives on Ken Wilber" med gästredaktörer Matti Kamppinen och J. P. Jakonen.

Man anordnade en internationell rundabordskonferens tillsammans med spetsenheten för religionsforskning vid Åbo Akademi, ”Young Adults and Religion in a Global Perspective" (YARG) den ${ }^{1} 3^{-1} 5$ december 20I7. Den $5^{-7}$ juni 2019 arrangerades symposiet "Approaching Esotericism and Mysticism: Cultural Influences".

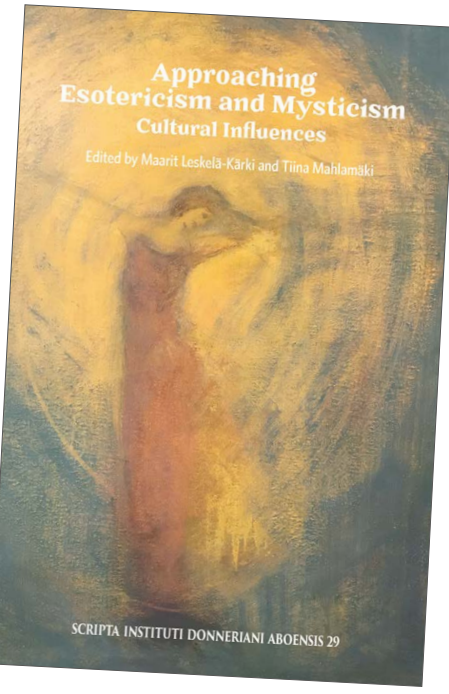
Bidragen publicerades i Scripta Instituti Donneriani Aboensis år 2020.

Att notera i anslutning till detta är projektet om modern esoterism och ockultism i Finland, ett projekt som huvudsakligen letts av Maarit Leskelä-Kärki och Tiina Mahlamäki vid finska Åbo universitet. Där har man haft ett projekt benämnt "Uuden etsijät" (ungf. Sökare efter det nya) en tid, som erhållit medel från Konestiftelsen. Ett resultat av detta är publikationen Moderni esoteerisuus ja okkultismi Suomessa (Modern esoterism och ockultism i Finland) som utkom våren 2020 (Vastapaino).

Det kan konstateras att den vetenskapliga forskningen i mysteriereligioner och ockultism väl omhändertagits av forskare knutna till Donnerska institutet. Därför kan sägas att institutets syfte väl förverkligats under senare år. Noteras bör att konstnärliga prestationer har fått alltmer plats vid konferenser och andra evenemang, något som säkert donatorerna sett med blida ögon. Olika former av musikframträdanden har blivit alltmer vanliga.

Under de allra senaste åren har även samarbete med det nygrundade Inez och Julius Polin -institutet för teologisk forskning påbörjats. Man kan här se en början till stark teologisk och religionsvetenskaplig forskning i en radie som sträcker sig till Uppsala och Stockholm. I Åbo finns två universitet med forskning inom religionsvetenskap. 


\section{Strategi för Donnerska institutet 2020-2022}

I den aktuella strategiplanen för Donnerska institutet 2020-2022 kan noteras att grunderna för verksamheten är vetenskaplig kvalitet, öppenhet och mångsidighet. I dagsläget kan flera styrkor identifieras inom biblioteks- och forskningsverksamheten. Donnerska institutet har etablerat sin position som ansedd aktör och samarbetspartner i både akademiska och samhälleliga sammanhang. Institutet har unika bibliotekssamlingar och samarbetsnätverk, samt tvärvetenskaplig profil och bredd.

Tyngdpunktsområdena är biblioteket, forskning, evenemang och öppen vetenskap. Accessionen är en integrerad del av bibliotekssystemet Alma Ex Libris. Vad forskningen beträffar bidrar institutet till att möjliggöra och stödja högklassig forskning i Finland, Norden och globalt genom stipendier, pris, utvecklande av nätverk, symposier och informationsresurser. Evenemangen och publikationerna stöder även ett kritiskt nytänkande och tvärvetenskaplighet på många områden.

Evenemanget syns i de regelbundet återkommande internationella vetenskapliga symposierna och rundabordskonferenser för vetenskapliga experter. Samarbetet med Aboagora, som är ett årligt, bredare publikt konst- och vetenskapsevenemang, fortgår.

Öppen vetenskap (open access) kan delas in i fyra delområden som innefattar hela forskningsprocessen från insamling och lagring av data till publicering och spridning av resultat: öppna data, öppen publicering, öppet lärande och öppen forskargemenskap. Donnerska institutet strävar efter att främja alla delområden i sin verksamhet och utvecklar verksamheten i nära samarbete med Åbo Akademis bibliotek, Vetenskapliga samfundens delegation m.fl. och allt förverkligas i nära samverkan med Åbo Akademis policy för öppen vetenskap och de infrastrukturer som utvecklas vid universitetet, nationellt och internationellt. Det föreligger även en separat handlingsplan för öppen vetenskap vid institutet. Där presenteras mer konkreta åtgärder för hur man ska lyckas i att utveckla institutet. 
Donnerska institutets bildsamlingar

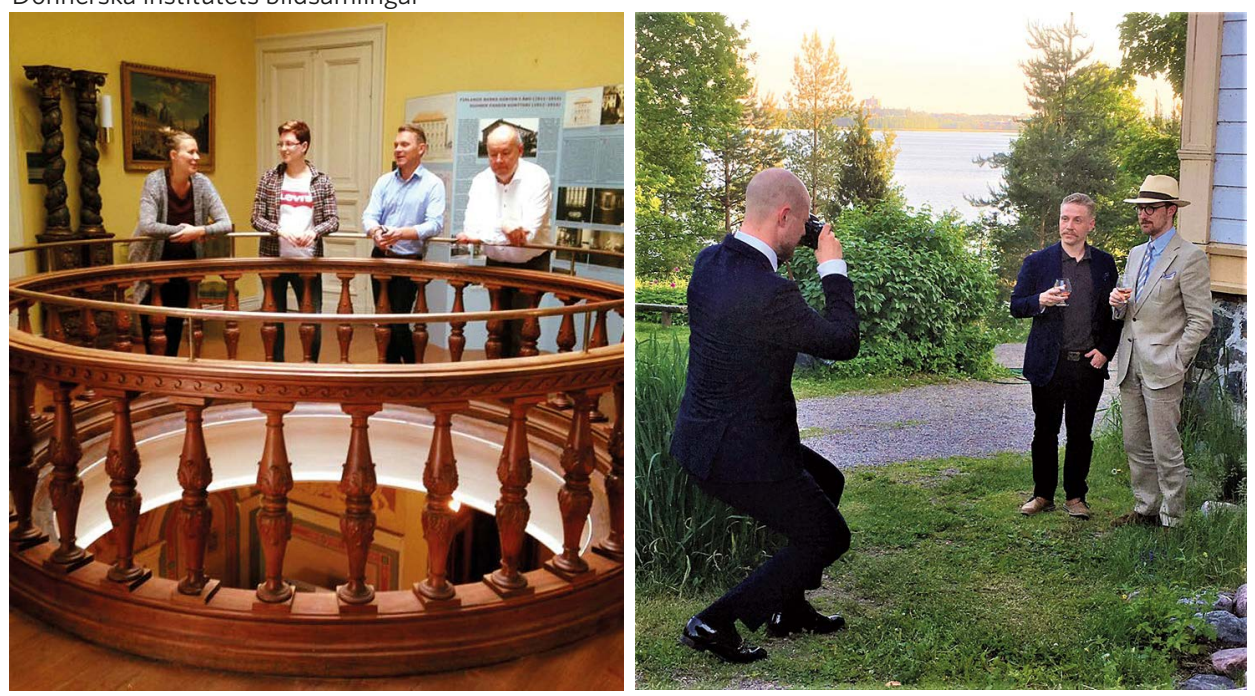

Uppe till vänster: institutets personal i Humanisticum.

Bilder från konferensen "Approaching Esotericism and Mysticism: Cultural Influences", juni 2019, besök vid Gallen-Kallela museet i Helsingfors och föreläsningssalen i ASAhuset, Åbo Akademi.
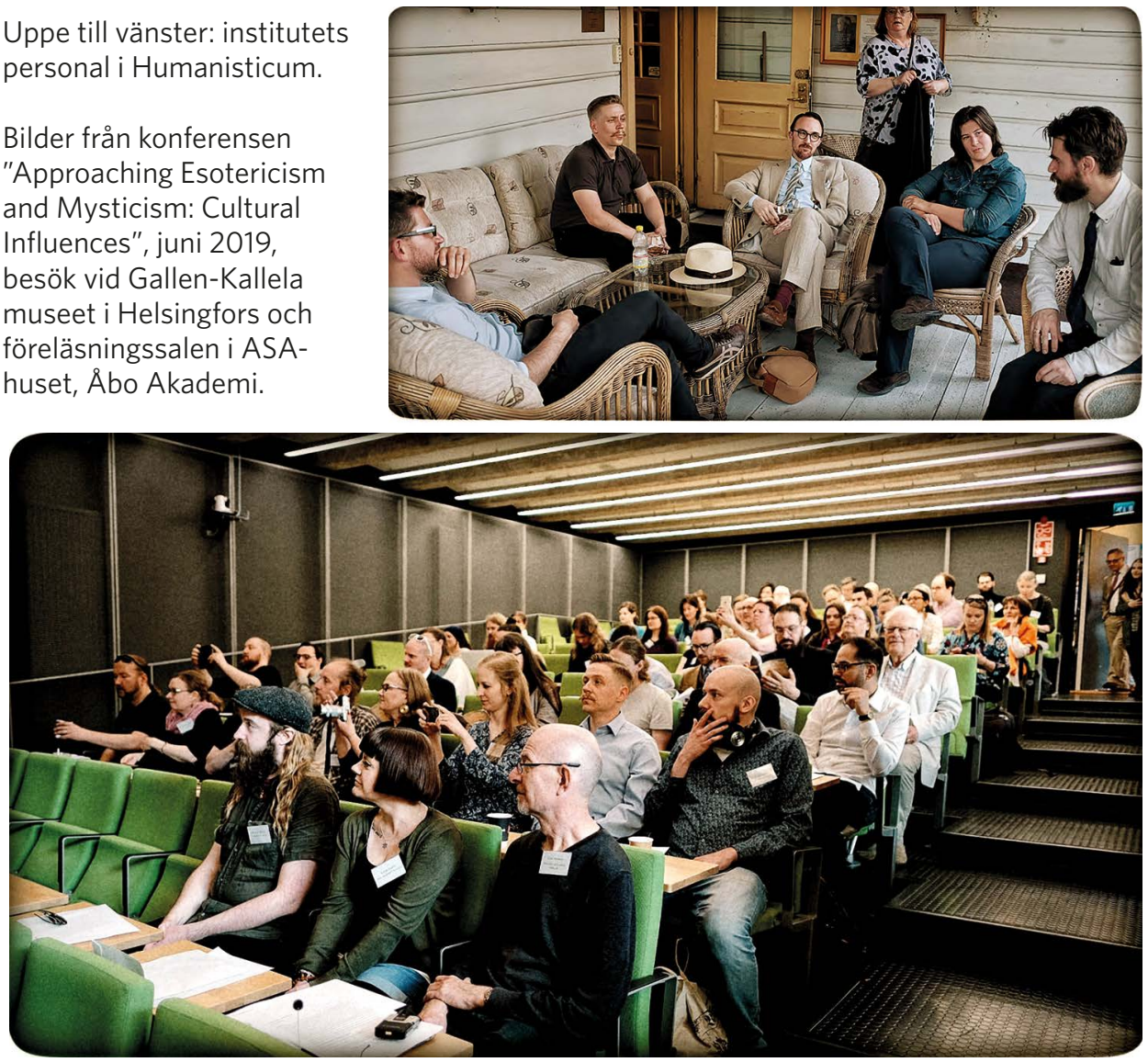


\section{Förändringar i det religiösa klimatet}

Det religiösa och kulturella klimatet i Finland och Sverige har förändrats markant under de drygt sextio åren Donnerska institutet verkat. Vi har sett hur donatorerna i början underströk en klar boskillnad mellan teologi och forskningen vid institutet. Vi har också sett hur man under institutets första årtionden försökt precisera det till teologi i betydelsen dogmatiskt bunden forskning.

I ett bredare samhälleligt kulturellt perspektiv har vi här att göra med en vidare samhällsutveckling. Större delen av samhället ville under I 900-talet frigöra sig från ett kvardröjande starkt, institutionellt inflytande från den evangelisk-lutherska kyrkans sida. Donatorernas skrivning kan förstås som ett sätt att gardera sig mot sådant kyrkligt inflytande.

Ännu vid mitten av r 900-talet fanns det ett synligt behov av en sådan markering. I Sverige hade t.ex. Ingemar Hedenius kring I950 skrivit två uppmärksammade böcker i vilka han kritiserade kyrkans och teologernas inflytande i det svenska samhället och över enskilda människors livssyn. I Svenskfinland hade en kyrkokritisk kulturelit varit inflytelserik sedan början av I 90o-talet.

Det var rätt vanligt på i 960- och I 970-talen att människor beklagade att man sysslade med religionsforskning. Religionen skulle ju dö ut och forskningen var därför onödig. En relativt tidig ändring av detta synsätt kom i och med revolutionen i Iran r 979. Då fick många upp ögonen för att religion kunde ha en samhällelig-politisk influens. Världsreligionerna fick då en betydligt större relevans i människors synsätt och föreställningar. Kultur- och religionskontakter noterades avsevärt mer i våra samhällen.

För de lutherska folkkyrkornas vidkommande blev utvecklingen motsatt. De förlorade största delen av sitt direkta inflytande. Man var tvungen att övergå från myndighetskyrka till intresseorganisation vid sidan av många andra. Det här fick utslag i ett ökat utträde ur kyrkorna både i Finland och Sverige. Över 9o \% av befolkningen hörde till kyrkan i Finland ännu kring år I 980. Kring 2020 var siffran nere vid 
70\%. I Sverige var förändringen ännu snabbare. Därmed tunnades spänningarna mellan olika sätt att förstå religionens roll i människors liv ut.

Förändringen kan ses som en allt starkare betoning av individualism hos de bredare lagren. "Jag tror på Gud, men inte som kyrkan lär" har blivit ett frekvent svar på enkätfrågor om personlig tro. Tiden har

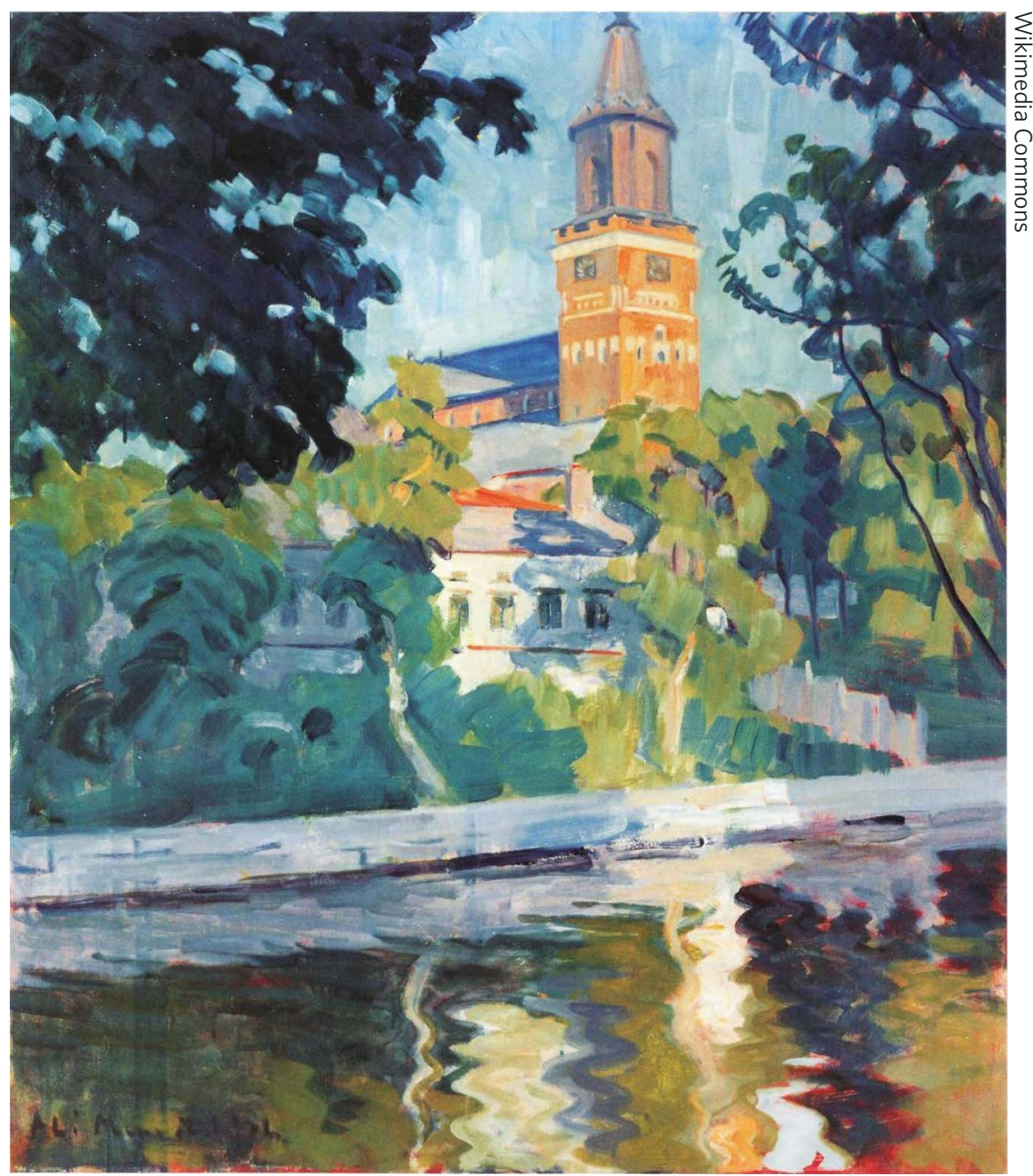

Ali Munsterhjelms målning av Åbo domkyrka. Olja på duk, 1920-tal. Konststiftelsen Meritas samlingar. 
samtidigt blivit alltmer öppen för religion och andlighet. Men många söker egna svar på frågorna. Forskningen talar om privatreligiositet.

Den samhällspolitiska debatten ville dock under hela r 9oo-talet lösgöra sig från religion. Politik och religion skulle inte blandas ihop. Också den här skarpa motsättningen började suddas ut under senare delen av förra seklet. Det nya millenniet förde med sig en ännu tydligare förändring. Tanken att utvecklingen gick mot alltmer religionslösa, helt sekulariserade västerländska samhällen, kraschade med de flygplan som störtade in i WTC-tornen i New York I I september 200I. Religion i olika former har igen börjat uppfattas som en betydelsefull del av människors liv, också på global nivå.

Det samtida samhälleligt-kulturella skeendet har medfört förändrade ramar också för verksamheten vid Donnerska institutet. Detta återspeglar sig tydligt i de delvis nya betoningar som vuxit fram och blivit tydliga under 2000-talets första årtionden. Ett slags grundläggande sediment av andlighet och religiositet i form av ockultism och esoterism tycks vara bestående eller återkommande i våra kulturer. Det utgör ju också ett av institutets främsta intresseområden.

\section{Den aktuella styrelsen}

Donnerska institutets styrelse består i slutet av år 2019 av professor emeritus Tage Kurtén, Åbo, ordf. och som suppleant docent Tiina Mahlamäki, Åbo universitet; från Uppsala professorerna Mia Lövheim, viceordförande och som suppleant professor Muhammad Fazlhashemi samt ytterligare från Åbo professor Peter Nynäs och som suppleant professor Lena Marander-Eklund.

\section{Mot framtiden}

Överblickar man utvecklingen av Donnerska institutet är det intressant att notera att man började med en idé om ett presensbibliotek där ett stort material insamlats. Helst skulle man sitta i biblioteket och låta sig inspireras av de värdefulla samlingarna. Allt detta kunde man 


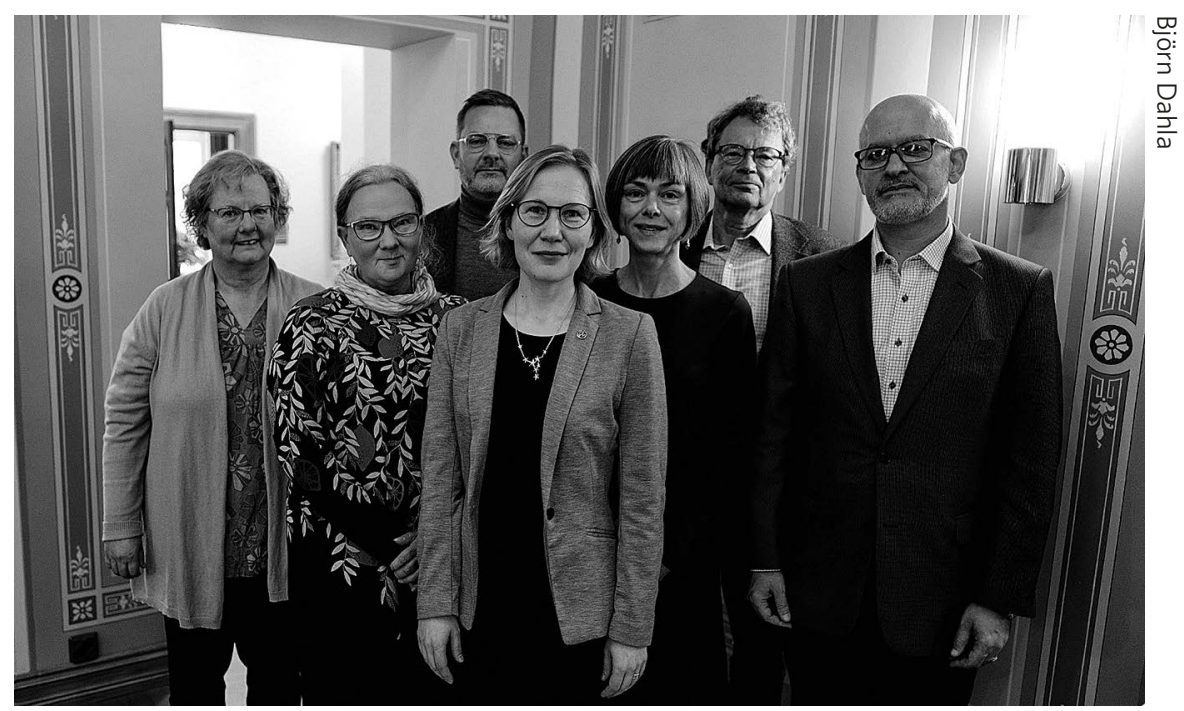

Donnerska institutets styrelse 2019-2022, från vänster: Lena Marander-Eklund, Tiina Mahlamäki, Peter Nynäs, Ruth IIIman, Mia Lövheim, Tage Kurtén och Mohammad Fazlhashemi.

ännu tänka sig på I950-talet men sedan internet kommit och utvecklats som det gjort är detta inte längre gångbart. $\mathrm{Nu}$ ska det vara open access och tillgång till allt material via internet. Var man än är i världen ska Donnerska institutets samlingar kunna nås.

Forskningsmässigt startade professuren så att man koncentrerade sig på ett lingvistiskt-genetiskt forskningsgrepp helt i gängse stil den tiden. Detta gällde i synnerhet de två första professorerna. Den tredje hade en klar inriktning på folklore och öppnade i övrigt på seminarierna upp för en mångfald infallsvinklar. Den fjärde professorn kom aldrig att arbeta som föreståndare eftersom akademin förstatligades och professuren flyttade över helt till humanistiska fakulteten. En beteendevetenskaplig orientering med bred vetenskapsteoretisk infallsvinkel och en betoning på aktiv religionsutövning med inslag av mystik och ockultism har kunnat bedrivas. Via adepter har detta även kommit institutet till del. De forskningsmässiga resurserna är begränsade vid institutet men har utvecklats positivt under senare år. Viktigare för forskningen är kanske då institutets ekonomiska satsningar på konferenser, rundabordsdiskussioner och sådant som Aboagora. 
Överblickar vi situationen för institutet nu på 2020-talet kan konstateras att stadgarna, tillämpningsbestämmelserna och strategierna reviderats ett par tre gånger. Varje gång har den vetenskapliga verksamheten betonats mer och mer, icke minst efter det att professuren lösgjorts från institutet. Det vetenskapliga arbetet är idag en självklarhet inom institutet och med nuvarande föreståndares dubbla doktorsexamen och fortsatta forskningar och engagemang inom en mängd vetenskapliga organisationer samt nyanställningen av en forskarbibliotekarie, är detta garanterat.

En annan sak som donatorerna säkert skulle ha sett med stor tillfredsställelse är att konsten återkommit. Vid sidan av rent vetenskapliga uppgifter syns satsningen på konst inte minst inom Aboagora och andra samarbetsprojekt. Satsningen på mystik och esoterism inom konferensverksamheten med goda publikationer på området är särskilt tillfredsställande. Allt Steiner-material finns kvar och kan vara föremål för forskning på samma sätt som det övriga. Med stor tillförsikt kan konstateras att donationsbrevets formuleringar om utforskandet av esoterism på vetenskaplig basis har förverkligats på ett lysande sätt. Allt ser därför ljust ut inför framtiden. Mystiken har sålunda blivit vetenskap och det förstått på flera sätt.

Landskap i motljus, tavla målad av Uno Donner år 1916. Enligt fil.dr Nina Kokkinen kan man i den här målningen se spår av antroposofins andliga natursyn och strävan efter harmoni. Talet tre, som återspeglas i trädmotivet, var centralt för antroposofins grundare Rudolf Steiner: den andliga utvecklingens väg har tre etapper och männsikans själ och psyke uppfattas som tredelade. Det vänstra trädet kan tänkas symbolisera den slutliga enheten. 


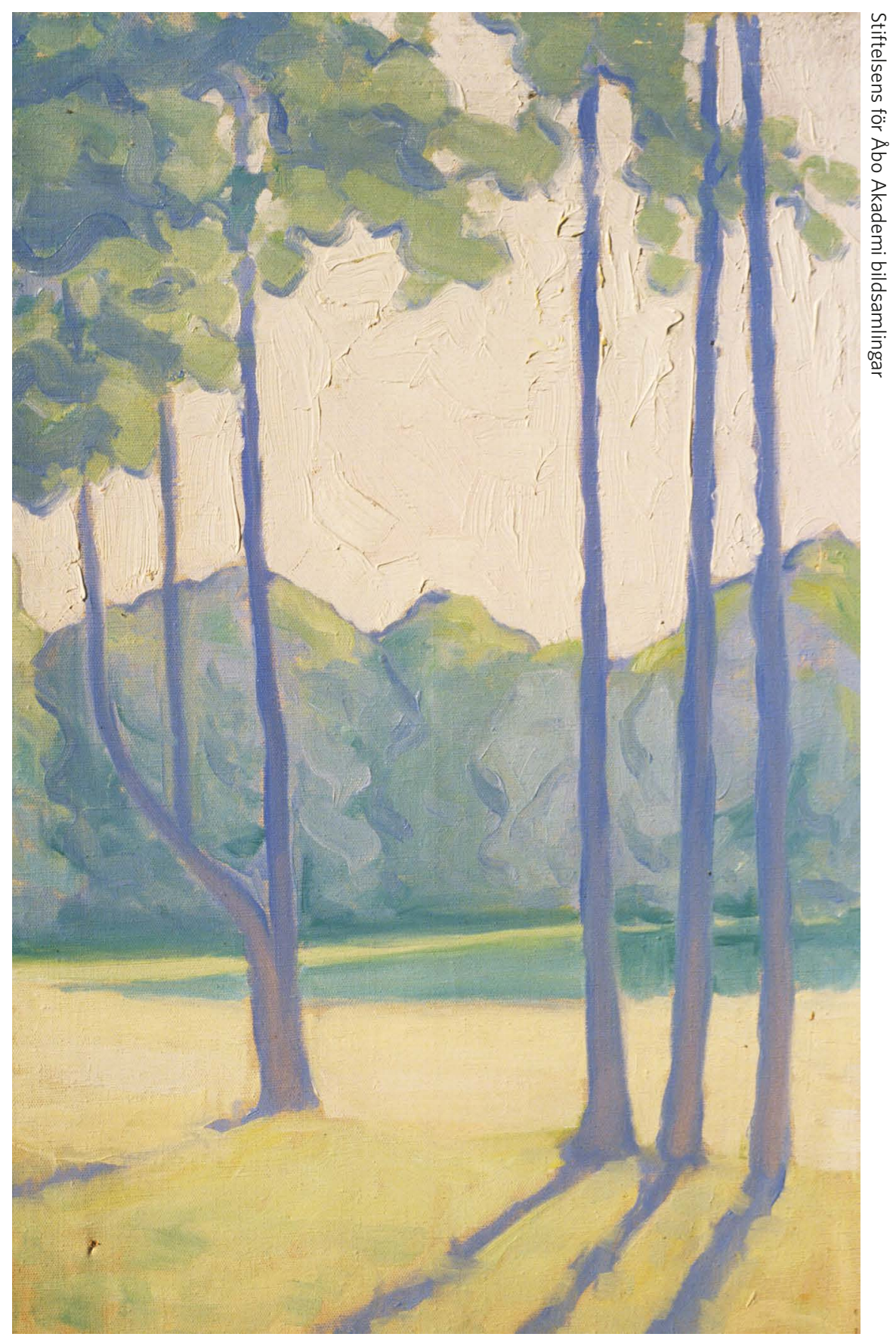




\section{Källor och litteratur}

\section{Otryckta källor}

\section{Donnerska institutet}

Bestämmelser för fonden för religions- och kulturhistorisk forskning, Arlesheim den 29 mars 1956 undertecknade av Olly Donner och U. Donner.

Donnerska institutets protokoll jämte bilagor I 958 -.

H. W. Donners brevsamling I 950-talet.

Lars Erik Taxells samling av dokument om grundandet av Donnerska institutet.

PM Högskolornas förvaltningsreform och Donnerska institutet.

Årsredogörelser och andra anteckningar om institutets verksamhet.

\section{Åbo Akademi}

\section{Centralarkivet}

Protokoll fört vid humanistiska fakultetens sammanträde tisdagen den I 9 november 1957 .

Protokoll fört vid humanistiska fakultetens sammanträde tisdagen den 26 november 1957 .

Utdrag ur protokoll fört vid humanistiska fakultetens sammanträde lördagen den 30 november 1957 i Konsistoriesalen.

Protokoll fört vid Konsistoriets sammanträde lördagen den 30 november $1957 \mathrm{kl}$. 2 i konsistoriesalen.

Protokoll fört vid förhandlingar som den I 5 mars I 958 ägde rum i Åbo Akademis konsistoriesal med Övervakaren av den Donnerska donationens verkställande, professor H. W. Donner. 
Stiftelsen för Åbo Akademi

Protokoll fört den 6 april 1956 vid Stiftelsens för Åbo Akademi styrelse.

\section{Intervjuer vårvintern 2020}

Tore Ahlbäck I 2.3.2020.

Joakim Alander 7.2.2020.

Björn Dahla 4.2.2020.

Ruth Illman 23.I.2020.

Nils och Siv Storå 27.2.2020.

Ulrika Wolf-Knuts I I.2.2020.

\section{Tryckta källor och litteratur}

Ahlbäck, Tore och Nils G. Holm. 2or 9. "Religionsvetenskap i Tvärminne - ett 40-årsjubileum", Uskonnontutkija - Religionsforskaren 8(I), doi: <https://doi.org/I0.24291/uskonnontutkija.v8i I.8300>. Berggren, Lars och Annette Landen. 20I 7. Väggarna talar. Äbo Akademis byggnader under hundra år (Åbo Akademis förlag).

Boguslawski, von, Julia, och Jasmine Westerlund. 20 I 8."Putting the spiritual into practice", Approaching Religion 8(I): 48-68.

Westerlund, Jasmine. "Vem var Olly Donner?”, Donnerska institutets webbsida, <https://www.donnerinstitute.fi/aktuellt-3/vem-varolly-donner/> (läst 20.10.2020).

Enkvist, Nils Erik. г 98 I." H. W. Donner", Arsskrift utgiven av Åbo Akademi 64/I979-80: 465-479.

Donner, H. W. I 959." Olly och Uno Donner”, Särtryck ur Arsskrift utgiven av Abo akademi 42.

Illman, Ruth. 20I 2. "Donnerska institutet: att arbeta som bibliotekarie vid ett vetenskapligt specialbibliotek", praktikuppsats i informationsförvaltning, Åbo Akademi.

Nordström, W. E. I 968. Academia Aboensis rediviva 1928-1968 (Ekenäs tryckeri). 
Scripta Instituti Donneriani Aboensis. Förteckning över volymer, $<$ https://journal.fi/scripta> (läst 20.10.2020).

Stadgar för Donnerska institutets för religionshistorisk och kulturhistorisk forskning, antagna av Stiftelsens för Åbo Akademi delegation den 27 april I $98 \mathrm{I}$.

Stiftelsens för Åbo Akademi delegations protokoll vid ordinarie mötet den I6 november 1959 i Akademiens konsistoriesal (kopia).

Sundman, C.-E. I 968. Åbo Akademis lärare och tjänstemän 1918-1968 (Åbo Akademi).

Sundman C.-E. 1978. Åbo Akademis lärare och tjänstemän 1968-1978 (Åbo Akademi).

Äbo Akademi 1918-1993. Forskning och institutioner II: bumanistiska fakulteten och teologiska fakulteten, red. Solveig Widén och Bengt Stenlund (Åbo Akademis förlag, r 993). 


\section{Personregister}

A

Ahlbäck, Tore 7, 29, 36, 37, 39, $40,42,43,44,45,46,48,52$

Ahola, Miika 54

Alander, Joakim 7, 53, 54, 55, 60

Allardt, Erik 29

Andersson, Claes 58

Andersson, Otto 33

Aro, Jussi 35

B

Baal, Jan van 40

Bergman, Jan 49

Bianchi, Ugo 4O, $4 \mathrm{I}$

Biezais, Haralds 30, 35, 36, 37,

$$
39,40,42
$$

Björkqvist, Kaj 36

Bloomer, Kent 60

Bondas, Johanna 38

Broo, Måns 56,6o

Bruun, Patrick 27, 38, 47

C

Chydenius, Johan 27

Czimbalmos, Mercédesz 60
D

Dahla, Björn 42, 53, 54, 57

Dahlsström, Ernst 5 I

Dahlström, Rosina $5 \mathrm{I}$

Doktór, Tadeusz 50

Donner, Heinrich Wolfgang

(H.W.) I 5, I6, I 7, I 8, 20,

2I, 22, 23, 24, 37, 47

Donner, Joachim Otto Evert

(J. O. E.) I 5 , I 7

Donner, Jörn I 4

Donner, Louise (f. Malm) I I

Donner, Olly (Olga) Io, I 2, I 3 ,

I 4, I 5, I6, I7, I 9, 24, 30

Donner, Uno 9, Io, I I, I 2, I 3 ,

I 4, I 6, I 7, I 8, I 9, 24, 30, 68

E

Edsman, Carl-Martin 2 I, 24, 25 , $26,27,29,33,34,37,4 \mathrm{I}, 46$, 47

Ehnmark, Erland 28

Ekman, Emilia Maria Matilda

I 7

Eliade, Mircea 40, 4I

Enkvist, Nils Erik 22, 23 
Eriksson-Katajainen, Birgitta 42,50

\section{F}

Fagerholm, Maj-Lis 38

Fazlhashemi, Muhammad 66, 67

Flemming, Christina 42

Fredriksson, Malin 53, 60

\section{G}

Gardberg, Carl-Rudolf 20, 2 I, 24

Gardell, Mattias 56

Gothóni, Réne 44

Grönblom, Rolf 49

Guillén, Oriol Poveda 56

$\mathrm{H}$

Haavio, Martti 29

Hakamies, Pekka 59

Hartman, Carl-Gustav 38

Hartman, Sven S. 30, 3 I, 33, 34

Hedenius, Ingemar 64

Helsing, Elmer 42

Hjärpe, Jan 42, 46

Holm, Dan 38

Holm, Nils G. 7, 29, 3 I, 32, 36,

$$
4 \mathrm{O}, 4 \mathrm{I}, 43,44,46,48
$$

Honko, Lauri 29, 34, 40, 4I, 44,

$$
45,57,59
$$

Hovi, Tuija 6 I

Hultberg, Thomas K:sson 36
Hultgård, Anders 46

Hultkrantz, Åke 40

Illman, Karl-Johan 4 I

Illman, Ruth 7, 52, 53, 54, 57, 58,

$$
60,67
$$

J

Jakonen, J. P. 6I

Junnonaho, Martti 44

Järvinen, Pertti 36, 42

K

Kamppinen, Matti 6 I

Kekkonen, Urho I6

Ketola, Kimmo 60

Kjöllerfeldt, Markus I 5

Klockars, Birgit 27

Kokkinen, Nina 68

Korkman, Julia 58

Kurtén, Tage 36, 60, 66, 67

Kuuva, Sari 6o

L

Lassenius, Tor-Erik I 6

Leskelä-Kärki, Maarit 6 I

Lévi-Strauss, Claude 32

Lillhannus, Noomi 54

Lindman, Sven 20, 2 I

Lundberg, Birgitta 33, 38, 39 
Lönnqvist, Harriet 42

Lövheim, Mia 6o, 66, 67

M

Magnusson, Magnus 36

Mahlamäki, Tiina 6I , 66, 67

Marander-Eklund, Lena 66, 67

Margul Tadeuzs 43

Martola, Nils 36, 39

Moberg, Jessica 56

Mustelin, Olof 25, 47

N

Niemi, Marja 38

Nikula, Oscar 2O, 2 I

Nordenstam, Anna ro

Nordström, Birgitta 60

Novis, Nurit 60

Nyberg, H. S. 2 I , 24, 28

Nyman, Anna 53, 54

Nynäs, Peter 46, 66, 67

Nystrand, Victoria 53

0

Olsson, Tord 49

P

Paret, Rudi 28

Pataricza, Dóra 6o

Pettersson, Thorleif 43

Pye, Michael 40
$\mathrm{R}$

Raphael, Melissa 60

Raudvere, Catharina 6o

Ringbom, Mårten 27

Ringbom, Sixten 25, 26, 27, 33, 38

Ringgren, Helmer 7, 21, 26, 28, 29, 30, 3 I, 33, 34, 37, 47, 57

Rosenberg, Tiina 58

Rosenberg, Ulla (senare

Andersson) 34, 38

Rosenqvist, G. O. 23

Runeberg, Arne 27

S

Salminen, Johannes 27

Sandelin, Karl-Gustav 36

Sarasvati, Bhaktisiddhanta 56

Sardella, Ferdinando 56

Saressalo, Lassi 4I

Schalk, Peter 42, 49

Sinikara, Kaisa 44

Sharpe, Eric J. 40

Sinebrychoff, Nicolas Io

Sjö, Sofia 55, 60

Skytte, Louise 36

Smart, Ninian 40

Smith, Dee 6o

Smith, W. Alan 60

Spiro, Melford E. 40

Steiner, Rudolf 9, I I I 8, I 9-20, 22, 26, 27, 50, 68

Stenius, Erik 2 I, 24 
Stolpe, Maud 42

Storå, Nils 27, 47

Storå, Siv 25, 27, 33, 38, 39

Ström, Åke V. 28

Sundback, Susan 36, 42, 44

Sundström, Margarete 25, 26, 27,33

Sundström, Olof I 9, 24, 27

Suojanen, Päivikki 44

Suolinna, Kirsti 45

Södergran, Edith 50

Söderholm, Märta 33

T

Taxell, Lars Erik I 8, 20, 2 I, 22, $23,24,37,39,47$

Tegengren, Helmer 20, 24, 29, 30, 34,37

Thesleff, Holger 27

U

Uggla, Bengt Kristensson 60

V

Veluppillai, A. 50

W

Waardenburg, Jacques 40

Wahlström, Bertel 37

Werblowsky, Zwi 4O, 4I

Westman, Rolf 27
Widengren, Geo 30

Wikander, Olof 2 I

Wikander, Stig 24

Wikman, Karl Robert Villehad

(K. Rob. V.) 21, 24, 27, 33

Wolf-Knuts, Ulrika 7, 3 I, 36, 38 , $42,59,60$

Z

Ziegler, Denise 6o

$\AA$

Åhman, Henrik 6o 